\title{
Let Them Eat Cake
}

\section{Gender, Nationalism and Tyranny}

\section{in Revolutionary France and Russia}

\author{
By \\ Hugh Eldred-Grigg
}

\begin{abstract}
A thesis
Submitted to the Victoria University of Wellington

in fulfilment of the requirements for the degree of

Master of Arts

in Political Science
\end{abstract}

Victoria University of Wellington

2010 


\section{$\underline{\text { ABSTRACT }}$}

The origin of the phrase 'let them eat cake' is obscure. Conversely, it is widely understood that the woman whose name is most associated with the phrase, Marie Antoinette, the last pre-revolutionary Queen of France, never said it. But despite its lack of veracity the phrase demonstrates neatly the degree of disdain and anger directed at the Queen to the point where hatred becomes a useful term.

This hatred was not unique to Marie Antoinette. While there is no phrase to highlight her role in the public eye, Alexandra Fedorovna, the last Czarina of Russia, was the focus of parallel disdain. Despite the timescale their situations are strikingly similar.

The French and Russian revolutions form the backdrop for the close of these two women's lives. Political historians de-emphasise the role of individual actors in shaping events, but the events of individual lives - or more precisely, the way in which those events are interpreted in the public sphere - can provide an insight into the impersonal events that constitute noteworthy targets of analysis.

This study identifies a common dynamic that explains the reason why Marie Antoinette and Alexandra Fedorovna were both the target of such intense hatred during the revolutions that overthrew the systems they were part of and contributed collectively and individually to the shaping of the modern world. 


\section{ACKNOWLEDGEMENTS}

I would like to thank the following people, without whom this thesis could not have been

completed. Whether they provided mentoring, emotional support, timely proof-reading or insight into the subject matter, I owe each of them my thanks. Needless to say any faults in this thesis are my own.

Aaron Wells

Aidenn Ossorio

Andrew Smith

Catherine Spiers

Christian Walker

Cordelia Black

Hannah Van Voorthuysen

Lauree Hunter

Malcolm McKinnon

Noel Ballantyne

Regan O'Neill

Richard Jones

Robyn Stroll

Rochelle Anne

Sarah Jane Barnett

Sarah Newman

Steve Barnes

Steven Eldred-Grigg 
And of course I would like to give particular thanks to my supervisor, Jon Johansson, whose support for my intellectual endeavours began many years before he formally became my thesis supervisor, and whose advice and support I hope to continue to be able to benefit from in the future.

Hugh Eldred-Grigg

July 2010 


\section{CONTENTS:}

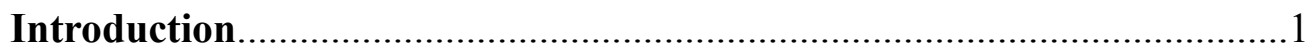

Chapter 1: The Ideology of Monarchy in France and Russia....................19

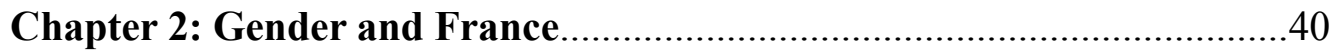

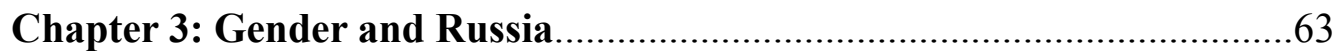

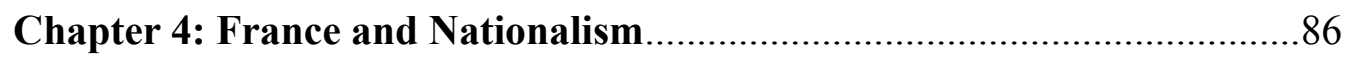

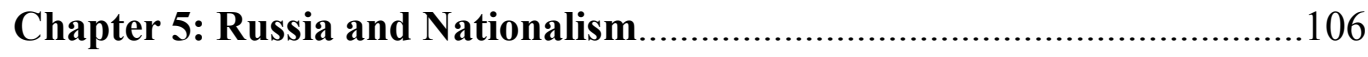

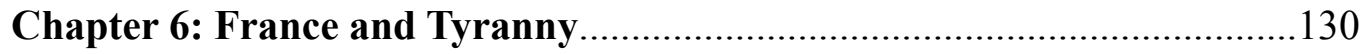

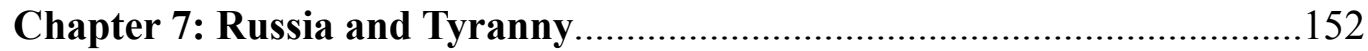

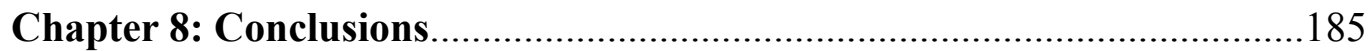

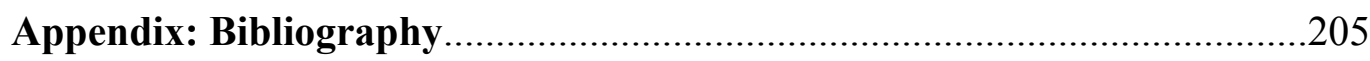




\section{INTRODUCTION:}

My dear philosopher, doesn't this appear to you to be the century of revolutions?

- Voltaire to d'Alembert

Comparing revolutions:

One of the more enduring legacies of the fall of the French monarchy is the popularity of the descriptive use of the word 'revolution' to apply to these events and others like them. The term is a contested one and has often been required to carry a very heavy conceptual weight, particularly among Marxist thinkers. At its least contested 'revolution' is a term that is appended to a historical event that involves a significant uprooting of established political practices. Whether or not a certain event can be considered a 'revolution' rather than a 'revolt', an 'uprising', a 'civil war' or one of many other terms available is a question that often attracts debate. But even the most minimalist, strict interpretations of the word will usually cede a handful of cases. In these cases the 'revolution' qualifier seems to be universally accepted. The least controversial of these events would be the French revolution, which spawned the term, and the Russian revolution in 1917.

It is tempting to dismiss the similarities between the revolutions of France and Russia as not advancing far beyond the shared nomenclature and a few correspondences that are either so broad (the prior monarchical government) or so narrow (the fact that both monarchs had only a single male heir) as to be meaningless. But while acknowledging the existence of very significant divergences in the contexts in which the French and Russian revolutionaries respectively operated is obligatory for any serious student of history, it has been suggested that the similarities are more than trivial. In her comparative study Theda Skocpol sees the cause of the breakdown of central 
authority that made revolution possible as the existence of significant barriers to attempts to make the state more administratively efficient through top-down reforms. ${ }^{1}$ Although there is a reason to take issue with Skocpol's focus on international diplomacy as stimulating the need for these reforms, the basic point is sufficiently valid to confirm that in comparing France and Russia we are comparing like with like.

Comparing like with like is of course the most important qualifier for any comparative study, but in the context of political science it is not the only one. In his 1971 paper Arend Lijphardt stated that comparative political studies are at their best when they have large sample sizes, when the case studies that constitute the sample sizes are as similar as possible in order to reduce the number of operative variables, when the analysis focuses on the operative variables and when variables are collapsed into one another when it is analytically justified. ${ }^{2}$ This thesis will seek to follow Lijphardt's guidelines as clearly as possible.

Unfortunately, increasing the number of case studies beyond France and Russia is not practical. The only revolution of similarly comprehensive depth in terms of its uprooting of the political institutions was, as Skocpol points out, that which occurred in Qing China in 1911. Although the referents that Skocpol used to present the three revolutions as a triad are valid, for the purposes of this thesis' analysis the Chinese case study is not helpful, as there is no single public woman to act as a point of reference for an analysis of gender ideas. ${ }^{3}$ To address another possible third case, Henrietta Maria, the spouse of England's Charles I, was similarly attacked on national, gendered

Skocpol, Theda. States \& Social Revolutions. Cambridge University Press, Ann Arbor, 1979. pp284-87.

Lijphardt, Arend, 'Comparative Politics and the Comparative Method' in The American Political Science Review, Vol 65, No 3, Sep 1971, pp686-91.

3 Empress Dowager Cixi does play a similar role to Marie Antoinette and Alexandra Fedorovna in many ways, but her status as a maternal figure rather than a spouse, not to mention the fact that she died before the events of 1911, means she is not suitable as a Chinese analogue for her French or Russian counterparts. This does not mean that an analysis of gender stereotypes in Chinese history and the manner in which they interacted with concepts of nationalism and tyranny, the latter of which in particular has an extremely rich grounding in Chinese political thought, would not be extremely interested, but without a central, high-profile political figure around which these concepts can coalesce the task is too weighty to be undertaken in this thesis. 
and tyranny-based grounds by the groups who eventually overthrew her husband. But although Skocpol acknowledges parallels in cause, course and outcome between the English Civil War and the French revolution that could potentially offer fertile grounds for comparison, she ultimately concludes that they are not of a type. ${ }^{4}$ This means that, while the English case may prove a useful referent, it cannot form one of the central pillars of analysis. We are left with only two cases for comparison, something that, while unavoidable, has potentially serious consequences for the strength of any conclusion, and requires careful adherence to Lijphardt's remaining guidelines.

This is particularly true of the last guideline - simplifying and thus strengthening analysis by attempting where possible to combine multiple variables into one. It is an attempt to fulfil this requirement that forms the central task of this thesis, as it will take three superficially independent variables - namely the role played by nationalism in the revolutionary public discourse and the parallel roles played by gender and concepts of tyranny - and demonstrate that they effectively formed a single narrative that was most aptly displayed in converging criticisms of Marie Antoinette and Alexandra Fedorovna, where it became increasingly difficult to discern exactly on which grounds the Queen was being attacked.

The causes of the French and Russian revolutions were not trivial. They were not caused by the personal qualities of the monarchs, or the short term decisions of their governments. They certainly were not caused by such discrete events as the mood of a crowd on a certain day, the judgement call of a critically placed individual, or the outcome of a certain battle. It is not the intent of this thesis to outline exactly what they were; the afore-mentioned extensive corpus of academic works covering both events contains no end of discussion of causation. But the idea that the revolutions were the products, not of impersonal and enduring economic forces or social cleavages, but of the interactions of relatively small numbers of people in constrained periods, is of interest. The search

\footnotetext{
$4 \quad$ Skocpol, pp141-3.
} 
for a single identifiable point at which the revolution can be said to have been 'caused' is not simply an attempt to narrow the task of analysis to the point of parody. It is also and more enduringly a mechanism for making sense of an event at a popular level, often as the event unfolds. Sometimes this mechanism is knowingly manipulated by revolutionary actors, even those who pride themselves on their keen insight into the actual workings of history - Leninism can be seen as much as anything else as an exploitation of this; the leadership exercised by the revolutionary vanguard is usually seen as a matter of organisation and goal-setting but it would be equally valid to describe it as a matter of story-telling, of creating a narrative for the consumption of the working class, albeit a narrative in which they find themselves in the starring role.

It is tempting to see the stories told in pre-literate societies as having educative, informative and otherwise positive value, to valorise them as methods for analysis and collective action in the pursuit of legitimate goals. Such an analysis exists as a rebuttal to the idea that these non-literate stories are somehow less sophisticated or useful for political mobilisation and discussion than those favoured by literate, bourgeois groups. This is true insofar as it goes, but the potential to create a countermyth must be avoided. While political folk narrative is no less valid than the specialist, highly literate formulations that are the default imagining when the word 'politics' is mentioned in a modern context, nor is it more valid. There is no reason to presume that the mere act of conveying political ideas in a less formal, or even a less hierarchical manner will result in a course of action that is bereft of harmful characteristics even if it does achieve what are ultimately socially progressive goals.

It is the intent of the comparative study that forms the heart of this thesis to demonstrate that the French and Russian revolutions were events with deep consequences but shallow causes. Lest this hypothesis be seen as inappropriately siding with nostalgists or traditionalists it has to be 
acknowledged quite clearly that whatever their long-term course, the revolutions removed regimes that were not responsive to the needs of the vast majority of their subjects. But it does not diminish the fact that these positive effects were often achieved through actions motivated, not by an understanding of the political context or even a more narrow dissatisfaction at the unequal distribution of wealth and opportunity, but rather by identification of threats that are essentially illusory. Again, there is no intent to displace or even dislodge either event from its status as a legitimate target of deep analysis; to attribute a system change to prejudices and unjustified fears does nothing to diminish its status as an important event. In fact the reverse is the case. It is the undoubted significance of the events of 1789 and 1917 that makes a careful study of their causes a worthwhile use of the author's time.

\section{Units of Comparison:}

The criticisms of Marie Antoinette and Alexandra Fedorovna can be differentiated into three broad, but telling categories. These categories are defined by the grounds on which the criticism was mounted, and subsequently by the assumptions on the part of the critics that made these criticisms possible.

Nationalist criticisms identified and castigated Marie Antoinette or Alexandra Fedorovna for their status as foreigners. For nationalist criticisms to exist the assumptions of nationalists regarding the primacy of the nation and the need for the state to conform to and serve it needed to be made.

Criticisms based on gender rely on gender stereotypes for their force. Those who made these criticisms held firm convictions about the existence of clearly delineated gender roles, and what those roles should be. Gender based criticisms were often subtle and relied as much on cultural 
constraints of femininity and masculinity as they did on the biological sex of individuals.

Tyranny based criticisms are in many ways the most complex. Although both 'gender' and 'nation' are ultimately ideas that exist only in the minds of individuals or collectives they are at least ideas that use conspicuous physical objects - human bodies or expanses of land - as their referents. Tyranny, by contrast, relies entirely on discrete and often secretive practices. Exactly what is meant by tyranny will be expanded on at a later point, but for the purposes of explaining the projected approach it is sufficient to note that criticisms based on tyranny make statements about the practice of governance and hold to account those who fail to meet a certain ethical standard of governance.

As will be seen this separation is problematic and cannot always be sustained. These three narratives mingle, merge, cross over and occasionally dissolve into one another. It is by examining the points of combination, and examining the manner in which they merge, we hope to be able to identify the true dynamic at work - the deep currents for which these ideas form the surface. By doing so we will reach a point where a firm statement can be made concerning the true dynamics of these two revolutions, and possibly broader still statements concerning the transition to modernity.

\section{Literature Review - France}

When the French monarchy fell, the history of its fall began to be written before it had even fully exited the scene. Nobody was more aware of the fact that what they were doing would be subject to minute and enduring analysis than the revolutionaries themselves. In their anxious expectations of a critical future audience for their deeds they were not disappointed. The French revolution is a continuing subject of historical interest and analysis, not just for those who wish to draw conclusions concerning the history of France or the character of government transitions, but to those 
who are interested in fields as diverse as economics, sociology, political and moral philosophy, religion and of course world system studies. Meditations on the course and meaning of events in France have produced some insights that endure far beyond any concern with the time and place that is ostensibly their subject.

The first history of the French revolution that escapes a simple blow-by-blow recounting of events is Edmund Burke's Reflections on the revolution in France. Burke's work illustrates the degree to which the French revolution became a touchstone for future political thought. The piece is a defining corpus of conservative ideology whose chapters carry ideas whose applicability goes far beyond any narrow discussion of what actually happened in France between 1789 and 1792. Even as Burke's text remains a living document frequently returned to and re-interpreted by both conservatives and their critics, its origin as a constrained commentary on a time, a place and a set of events in that time and place needs to be acknowledged. There are few other such places in history where an analysis can transfer in so ready and satisfying a fashion from particular consideration to wide-ranging prescription. Burke saw the revolution as an unwelcome innovation that unnecessarily alienated French society from itself. The most illustrative phrase is Burke's admonition of the revolutionaries when he abjures them that:

"You began ill, because you began by despising everything that belonged to you." 5

Burke's view of the French revolution was that it was essentially inauthentic, alien to settled French life and by extension to the human need for reliable, steady, time-tested practices.

The next major scholarly review of the revolution and the first written from within France was Alexis de Tocqueville's The Ancien Regime and the Revolution. Tocqueville, although Burke's

\footnotetext{
5 Burke, Edmund, Reflections on the Revolution in France, J Doddlsey, Pall Mall, 1790, p51.
} 
equal in his disdain for the revolution, spent more time commenting on the errors of the prerevolutionary monarchs, and de-emphasised the radical nature of the revolutionary break. Although he described the revolution as "stupendous" he qualified this immediately by stating of the revolution:

"Its sole effect was to abolish those institutions ... which are usually known as the feudal system"6

More recent scholarship has unsurprisingly tended to view the revolution in a more positive light. Writing in the 1960s, Barrington Moore Jr followed de Toqueville's analysis of the causes of the revolution as lying in the practices of the ancien regime and paying particular attention to the practice of the sale of offices. ${ }^{7}$ Although he acknowledges the violence implicit in the revolution Barrington Moore ultimately views it as:

"... a crucial point for France on the long road towards democracy."

Although Moore argues that the revolution was not necessarily a universal requirement his argument is less grounded in appeals to ancient tradition, as with Burke, or the generic impossibility of effecting deliberate change, as with Tocqueville, but in the specific economic practices of the pre-revolutionary governments.

Post-Moore writers have tended to view the economic questions of the revolution as less contentious and focused instead on the culture and language of the revolutionaries. Although this

This seeming contradiction is a firm expression of de Toqueville's conservatism, as even this relatively limited change is seen as 'stupendous'. De Toqueville, Alexis. The Old Regime and the French Revolution, trans John Bonner, Harper \& Bros, Franklin Square, 1856, pp35-6.

7 Moore, Barrington Jr, Social Origins of Dictatorship \& Democracy, Penguin, London, 1991, pp42-3, 48-9.

8 Moore, p108. Emphasis is the original's. 
might appear to be a retreat from substantive, material issues, scholars who examine the cultural viewpoint of the revolution are not stepping back to Burke's position of refusing to look past the storied traditions of practice, but instead examine the way material circumstances were understood and communicated by revolutionary actors, with as close a focus on those outside the revolutionary leadership as is possible given the relative invisibility of the illiterate underclass in the historical record.

One of the foremost such authors is Lynn Hunt. Hunt's book, The Family Romance of the French revolution, aims to explain on these grounds. Hunt states in her preface that

"I will be arguing that the French had a kind of collective political unconscious that was structured by narratives". 9

Hunt's exploration of this unconscious is based largely on metaphors relating to families, but there is no reason to believe that ideas of family solely comprised it. Hunt's work readily extends itself into more generalised exploration of gender roles, which in turn leads to broader unconscious landscapes concerning similarly potent political narratives.

9 Hunt, Lynn, The Family Romance of the French Revolution, University of California Press, Berkeley, 1992, p xiii. 


\section{Literature Review - Russia}

One of the many commonalities between the French and Russian revolutions was the equal preoccupation shared by their participants in playing to the historical stage. In Russia many of the chief protagonists of the revolution considered themselves historians of their own actions as well as actors. The most prolific of such politician-historians was Leon Trotsky, whose The History of the Russian revolution offered a tidy explanation of the causes, course and effect of the revolution in Russia. Trotsky states that:

\footnotetext{
"The masses go into a revolution not with a prepared plan of social reconstruction, but with a sharp feeling that they cannot endure... the fundamental political process of the revolution thus consists in the gradual comprehension by a class of the problems arising from the social crisis - the active orientation of the masses by a method of successive approximations." 10
}

Trotsky's contemporary Max Weber took an entirely different and more personal view of the causes of the revolution. Weber saw the revolution as almost entirely a product of great power diplomacy and personalities, placing blame for the fall of the House of Romanov on the shoulders of Czar Nicholas. Weber proclaims that, in avoiding a revolution;
"What is descisive for success is: (1) that their resolutions are not interfered with by the notions of a monarch so lacking in political talents; (2) that they have the freely given dedicated support of a sufficiently broad, powerful social stratum; (3) that they know how power struggles are carried out in situations where regulations, commands and

\footnotetext{
10 Trotsky, Leon. The History of the Russian Revolution, Vol 1: The Overthrow of Czarism, trans Max Eastman, Victor Gollancz, London, 1934, p18.
} 
military or bureaucratic obedience are not, in the nature of things, appropriate methods." 11

While Weber's focus on personalities appears to differ strongly from Trotsky's the two are capable of being reconciled. Although he claims that "Great politics is always achieved by small groups of people", points (2) and (3) seem to imply that navigating through indirect mass politics is the only way these small groups can achieve anything. The particular stress on the appropriateness of informal methods speaks to Trotsky's emphasis on 'approximations'.

The fall of the Soviet Union prompted a new examination of the Russian revolution, most of it critical of the revolutionaries. Richard Pipes, the most prominent anti-Soviet Russian historian, sees a commonality between the the Czarist and Soviet governments. Pipes argues;

"Even someone entirely ignorant of Russia should find it inconceivable that on a single day, October 25, 1917, in consequence of an armed putsch, the course of the thousand-year-old history of a vast and populous country could undergo complete transformation... it takes great faith in the power of decrees, even decrees backed by physical force, to believe in the possibility of such drastic mutation, unknown to nature."12

Pipes effectively denies there was anything revolutionary about the revolution. His approach is similar to Toqueville's approach to France, except taken one step further. This perspective is conservative both in the deep sense, in that it views human societies as effectively unchangeable, but also in the more narrow contemporary sense of viewing Russia as innately inferior to the liberalcapitalist west.

11 Weber, Max, 'Pseudo-Democracy' in The Russian Revolutions, trans Gordon C Wells and Peter Baehr, Polity Press, Cambridge, 1995, p245.

12 Pipes, Richard, A Concise History of the Russian Revolution, Random House, New York, 1995, p396. 
Pipes' approach is unhelpful as it denies the significance of the events of 1917. An alternative approach, while still critical of both the pre and post 1917 regimes, is that taken by Orlando Figes in People's Tragedy. Figes, in a case study centred on a Russian peasant known as Kanatchikov, explains how

\footnotetext{
"The workers also liked to read stories about the popular struggle for liberation in foreign lands. 'Whether it was the Albigenses battling against the Inquisition, the Garibaldians, or the Bulgarian nationalists, we saw them all as our kindred spirits,' wrote Kanatchikov. It did not matter that these foreign heroes had fought very different battles from their own, since the workers were quick to reinterpret these stories in the Russian context."13
}

This appropriate of romantic imagery of struggle and resistance, devoid of context, is a concrete example of Trotsky's 'approximations' or Weber's 'appropriate methods'. They are also consistent with Lynn Hunt's focus on the 'unconscious'.

\section{Methodology:}

Faithful to Lijphardt's guidelines for rigorous comparative political analysis, this thesis will attempt to analyse the narratives that arose during the French and Russian revolutions. It is felt that these narratives, as they relate to gender, nationalism, tyranny or some combination of the three, will reveal a common heritage to the two revolutions.

The source of these narratives will, as much as possible, derive from primary sources from the periods leading up to and during the revolutionary events. Unfortunately there is a limit to the

13 Figes, Orlando, People’s Tragedy, Johnathan Cape, London, 1996, p119. 
accessibility of primary sources, so it will be necessary to rely on the work of historians such as Hunt and Figes who have collated primary sources in their own works and to review, although not uncritically, their conclusions. 


\section{CHAPTER ONE:}

\section{THE IDEOLOGY OF MONARCHY IN FRANCE AND RUSSIA}

It is not possible to reign innocently.

- Antoine St Just

Before discussing the narratives that arose during the overthrow of the French and Russian monarchies it is necessary to examine the narratives that they displaced. From the modern perspective it can be difficult not to see absolutist monarchies as intellectually sterile and incurious institutions grounded on static reverence for tradition and absolute deference. To be sure, to make a claim that unusual vitality was a feature of the intellectual landscape of absolute monarchy would be to indulge in apologetics. Neither the Russian nor French monarchies were able to create an idea of nation, of gender or of tyranny that could be wholly and unproblematically nested within the intellectual framework of absolutism. But even when rigid traditionalism and deference did exist, there was no shortage of intellectual activity by their proponents devoted to explaining and justifying their existence. This intellectual activity formed a series of narratives that, even if they were autocratic narratives about autocracy, are valuable even if only in what they can tell us about what displaced them.

It does not necessarily follow that thought that takes place under the reign of a monarchy is monarchist thought. Nor does monarchist thought stop when monarchy ends, or even when hope of a restoration fades; however, although the field is fascinating from a purely academic perspective it is unlikely to be profitable, when examining ideas about nationalism, gender and tyranny during anti-monarchist revolutions, to delve into the dense literature about monarchy generated in the 
periods long after the initial fall of the monarchy ${ }^{14}$. But debate about the monarchy which takes place immediately after or during the process of disestablishing the monarchical state is an extremely valuable source. Indeed it seems that ideas about the nature of monarchy as an institution, as compared to other institutions, are more commonly found among anti-monarchists than among monarchists. This is not altogether surprising; pro-monarchist theorists in the prerevolutionary period tended to take the basic justification of the monarchy for granted and emphasised differences between various types of monarchy, or the reign of individual monarchs (or their ministers) in discussing good and bad government. Anti-monarchists necessarily took monarchy as a single, holistic concept in order to contrast it with non-monarchy. This chapter will spend as much time discussing revolutionary ideas of monarchy as it does monarchist ideas. It is acknowledged that in doing so an artificial dichotomy is created; there were many monarchists who supported only certain, relatively limited ('constitutional') forms of monarchy and who would have potentially felt a greater ideological identification with anti-monarchist revolutionaries than their absolutist colleagues. However, given that the distinction is being made only for reasons of clarity, it can be sustained for the duration of this chapter, although the gap between proponents of limited monarchy and abolitionist republicans will be examined more closely when discussing narratives during the revolutions themselves.

This section will not look at the policies of the monarchies in question, nor at the individual personalities and practices of specific monarchs. It will instead attempt to look as closely as possible at monarchies as a theoretical construct, even when the actual practices of monarchies did not match this concept closely. This line will often be hard to draw - the gradation between a policy introduced by a monarchy on a particular area, such as gender, and the gender element in the monarchy's ideology is very difficult to construct, as it is hard to draw a clear line between anti-

\footnotetext{
14 An enormous amount was written about monarchy in France in the $19^{\text {th }}$ and early $20^{\text {th }}$ centuries, ironically mostly after the periods of the Bourbon restoration (1815-30) and the July monarchy (1830-1848). Similarly Soviet and post-Soviet scholars have spent much time discussing the institution of monarchy in Russia.
} 
monarchist construction of the flaws in monarchy and the flaws of the actions of a particular monarch, particularly while attempting to give due consideration to popular and impromptu antimonarchist constructions. Nonetheless, it is hoped that a careful analysis of the ideological directions in which monarchies moved will prove useful when this thesis moves on to consider their deconstruction.

\section{Nationalism and the French monarchy:}

In considering nationalism as it relates to the French and Russian revolutions this thesis will use the definition of nationalism utilised by Benedict Anderson. ${ }^{15}$ Any study of the history of nationalism with Anderson's work in mind immediately encounters the obstacle, noted by the author himself, that the word nation has a heritage that substantially predates the ideology of nationalism. French monarchists often spoke of the King's service to the French nation, and it is tempting to assume that a strong link was being drawn between nationalism and the institutions of monarchy. This was not the case. Instead, the word referred simply to a group of people from a particular area, rather as 'people' might be used to today. There were no connotations of political legitimacy. Monarchist theory justified the King's status as one owing directly to god. As such the King's activities were directed as much towards an international audience (his fellow sovereigns) or a post-vital audience (divine judgement) as they were towards any contemporary community, let alone an organically national one. The apocryphal statement attributed to Louis XIV, “l'etat, c'est moi”, is not just a statement of political absolutism (although it is certainly that); it is also an abnegation of the concept of nationalism. It is true that by the time of the revolution Louis XIV had become a distant figure and neither of his successors could have been credibly portrayed as making an identical statement. Louis XVI, for example, preferred to depict himself as a father and a family man rather than a heavenly prince or divine trustee. But while these conflicting versions of absolutism -

\footnotetext{
15 Anderson, Benedict. Imagined Communities. Verso, London, 1991.
} 
divine/heroic and paternal/familial - differed in many ways, Louis XVI's approach was no more open to nationalism than Louis XIV's. The idea of the nation as a family was an attractive metaphor for nationalist thinkers, but the emphasis placed by Louis XVI on the father's role, rather than a community of siblings/kin, implies an entirely different model. If a nation is a family it is a family of adult children, and the father's role is primarily generative and nurturing, not educatory (to say nothing of authoritative).

The monarchy did often use language which superficially appeared to be nationalist, in denying or decrying the ability of other states to influence the affairs of the realm of France or by imputing some special status to the subjects of France which marked them as superior, or at least objectively different from, the subjects of other realms. While this rhetoric would prove useful for nationalists such as Jules Michelet, who wished to establish a firm tradition of nationalism dating to the earliest days of the French state, the resemblance was only superficial. Religious gallicanism is a good example of a tradition that appears at first glance to have been a nationalist phenomenon but was actually a dynastic one. When Louis XIV refused to follow the Pope's wishes regarding the Huguenots, he did so not because he felt that it would be illegitimate to allow non-French actors to direct the lives of French people; he did so because France was his patrimony and he its only legitimate representative. In other words, he saw France as his property, and the Pope as a trespasser.

Some scholars have identified the debates between the various regional parlements and the King over religious liberties as the beginning of a nationalist idea of monarchy. The theory is that in setting themselves up as the defenders of Gallic liberties, the parlements were implicitly criticising the King for failing in his nationalist duty. This theory goes on to portray the debate as one over who could more effectively represent the French nation. This theory is attractive but it misses a 
crucial point. The liberties in question were attached not to the French populace but to the elements in the French state. Their origin was not the claims of a single people but a series of agreements negotiated between the monarchy and various regional or sectional actors. The relationship was one of contract, and the rights acquired by contract were termed 'gallic' only to emphasise that they emanated from the office of the King. Only the specific circumstances of the debate prevented the parlements from terming these liberties 'royal liberties', as they were debating with the King himself - even though they were effectively accusing the King of being untrue to himself. It is also worth noting that the parlements and more generally the noble class from which they recruited saw their particular regions - eg Brittany, Burgundy, Languedoc or elsewhere - as legitimate "national" entities at least as much, if not more so, than France itself. It has been shown that provincial nobles generally saw lending money to provincial institutions as more prestigious than lending them to central government. Keeping this fact in mind it becomes clear that the parlements did not promote a nationalist view of monarchy.

The anti-monarchist view of the monarchy's relationship with the nation was, ironically, in agreement with the monarchical view. Both monarchists and revolutionaries agreed that the monarchy was inconsistent with the existence of the nation; the difference was in the value assigned to the nation, which was neglible to monarchists, but paramount to revolutionaries. Even during the early stage of the revolution, when the revolutionary project provided for the retention of the office of the King, it explicitly separated the office of King of France and the person of 'Louis Capet'. Revolutionary festival rituals that incorporated the King separated and subordinated him to representations of the nation.

Later, the King was seen, not only as separate from the nation, but antithetical to it. Saint-Just's famous quote, reproduced at the beginning of this chapter, is an illustration of this principle, but he 
put it more succinctly later when he stated "To judge is to apply the law; law supposes a common share in justice; and what justice can be common to humanity and kings?" ${ }^{16}$. While Saint Just does not explicitly mention la nation, to put the King outside humanity is to put him outside the nation (as well as many other concepts). To the revolutionaries who voted for Louis' execution, it was in the end not possible to separate the person of the King from the office; it was not possible for Louis Capet to simply be Louis Capet, for even without any of the powers, benefits or trappings of the office he was still a King; having alienated himself from the nation by the act of assuming the crown, he was not able to de-alienate himself. Kings, in other words, existed so far outside the national concept that, once they had departed, they could not return.

But even if we step back from the execution of the King and look at the institution of monarchy as a whole, the revolutionary view remained that monarchy was antithetical to the existence of the nation. Revolutionaries did not deny that the nation had existed under the monarchy - indeed, they usually viewed the nation as eternal - but any 'green shoots' of national identity that were identified as co-existing alongside or even within monarchical institutions were generally seen as products of the unconquerable spirit of the French people rather than due to any positive relationship between the institution of monarchy and the principle of the nation. Nationalist thought, as Gellner has illustrated, requires a belief in the ability of the nation to go into what he termed an 'Occultation'. Occultation as defined by Gellner was a state that could account for the fact that a nation's identity was so profoundly authentic as to be incapable of being eliminated, but not so eternally dominant as to never require the assertions of nationalists to elevate it to the political prominence that was its rightful place. ${ }^{17}$ French revolutionaries would likely have explained the existence of the nation under the monarchy as a near ideal example of this phenomenon.

\footnotetext{
16 Saint-Just, speech of 13 November 1792, in Dunn, Susan, The Many Deaths of Louis XVI, Princeton University Press, Princeton, 1994, p17

17 Gellner, Ernest, Nationalism, New York University Press, New York, 1997, pp7-9.
} 


\section{Gender and the French Monarchy:}

This essay will use the definition of gender established by Judith Butler in Gender Trouble. ${ }^{18}$

Although Butler's definition is controversial it is the most useful in this context, in that it establishes gender performance as the sole component of gender identity. This is the most useful for any research that seeks to concern itself chiefly with claims made on behalf of gender roles in the public sphere.

To investigate the role of gender in the monarchy does not necessarily mean to investigate the role of gender under the monarchy. Sexual relations and the ability of women in ancien regime France to access power are a fertile field of study but for the purposes of this thesis, gender relations in society as a whole are relevant only to the extent that they affect perceptions of gender within the institutions of monarchical government.

If monarchy is defined as a system where supreme power is passed on by the principle of hereditary succession it is necessary for women to participate, as only women are capable of giving the monarch offspring. Monarchies, like other systems of power, need to prove that they are in control not just in the present but will remain so in the future; it will be extremely hard to attract support or distribute patronage if there is no assurance that rewards given today cannot be withdrawn tomorrow. To successfully create this expectation of future power, a hereditary system requires an heir whose legitimacy is beyond all but extraordinary challenge. Preferably there should be multiple heirs ${ }^{19}$. This meant that not only must the heir be the biological child of the monarch, they must be the biological child of the monarch's legitimate spouse. Effectively, the monarch's spouse,

Butler, Judith. Gender Trouble. Routledge, London, 1990.

19 Infant mortality was high in both $18^{\text {th }}$ century France and early $20^{\text {th }}$ century Russia, meaning that accidental death was something even those with access to the best medical care technology could make available could not afford to dismiss. It is worth noting that both Nicholas II and Louis XVI had only one male heir, but this is a trivial similarity. 
a female figure, was at the very centre of the monarchy's ability to project power into the future, and as such at the centre of the monarchy's ability to command practical obedience. When the heir proceeded to become the reigning monarch, if his mother survived she would continue to occupy a place of ceremonial prominence which could parallel or even exceed that of her daughter-in-law, the queen consort - her continued presence was a reminder of the monarch's past-derived legitimacy just as the queen consort's was a guarantor of his future legitimacy.

This construction makes hereditary monarchy as practiced in France seem a fairly female-centric system of government. This needs to be qualified. In France, thanks to the principle known as the Salic Law, women were explicitly unable to succeed to the crown and thus unable to achieve supreme political power. Throughout the early days of French monarchy the exact justification for female exclusion from the throne was debated extensively but it appears that the principle that women should not reign was never seriously called into question; Christine de Pizan, a $15^{\text {th }}$ century female writer, accepted that women could not serve as judges or magistrates, let alone monarchs, and confined herself only to arguing that they did not lack the intellectual capacity to do so. ${ }^{20}$ Amid all of the arguments regarding female inability to lead during war, administer the law or fulfil the priestly functions of monarchy, as well as xenophobic concerns that foreign princes would come to power through marrying female French royals, the overriding concern is that women should not exercise power. It is hard not to conclude that the idea that monarchy was not an institution that women could participate in was very broadly accepted. It is worth noting that despite this, women were often able to effectively exercise the power of monarchs in France, by ruling as regents for under-age sons. But in defending their right to do so they were required to genuflect to the concept that females were not eligible to rule. In 1525 Louise de Savoy was able to convince a parlement to recognise her as regent by presenting herself as exercising a familial, not a personal, right. ${ }^{21}$ It

20 For a discussion of contemporary political thought on the Salic Law see Taylor, Craig, 'The Salic Law and the Valois succession to the French Crown', in French History, Vol 15, Dec 2001, pp-358-377, Oxford University Press. 21 Craig, p374. 
seems that the concept of a particular woman exercising power was acceptable providing that the general principle of female ineligibility was respected. ${ }^{22}$ This symbolic refusal only gathered strength as time journeyed on; Marie de Medici was the last Queen of France to be crowned (in 1600); her successors lacked such independent sacramental authority for their status.

But power in monarchy is not always or even usually restricted to the person who formally occupies the throne. Several women were able to rise to substantial political power, notably Madame Pompadour, whose influence was akin to that of a modern day prime minister and who played a substantial role in directing French policy, particularly foreign affairs. Despite the fact that these favourites and kitchen cabinets would often be decried by groups, such as the parlements mentioned earlier, who wished to oppose the policy of the monarchy without opposing the institution, they were common enough that they can generally be seen as part of the system of monarchy, and many monarchist theorists would enthusiastically defend the King's right to surround himself with whichever individuals he wished to associate. Obviously the King's consort/wife was very likely to be one such person. ${ }^{23}$ The right of the woman to advise her husband was held highly by monarchist theorists and was quoted by Marie Antoinette at her trial. This right must, however, be seen as very limited, and while figures such as Pompadour were able to exercise very real power they needed to do so through the fiction of the supremacy of the monarch.

The revolutionaries often derided the ancient regime for being feminine, citing the influence of figures such as Madame de Pompadour, her successor Madame Du Barry or Marie Antoinette herself. Revolutionary discourses on gender are uneven; some saw the fall of the monarchy as

\footnotetext{
${ }^{22}$ Kathryn Norberg argues that the Salic law ironically had the effect of making a Queen a very attractive choice of Regent, as she would be unable to usurp the throne during her custodianship. Norberg, Kathryn, 'IncorporatingWomen/Gender into French History Courses, 1429-1789: Did Women of the Old Regime have a Political History?' in French Historical Studies, Vol 27, No 2, Spring 2004, p252, Duke University Press.

23 This was not always the case. Louis XVI's hapless Polish wife, Maria Leszczynska, had little influence even on her husband's Polish policy. Marie Antoinette, by contrast, while not quite the puppet mistress she appeared to be in revolutionary polemics, was able to exercise substantial control over some aspects of policy.
} 
liberating the women of France, others saw it as liberating France from women; some took the seemingly paradoxical position of celebrating both. The incursions of women into the public sphere during the monarchy were a recurring focus of revolutionary thinkers and even after the establishment of republican government, many republicans were extremely suspicious of women who attempted to play a role in public life, seeing them as potential agents for monarchical and (particularly) clerical subversion of the republican state. When Marat was assassinated by Charlotte Corday, the subsequent funeral and eulogies carried a very strong strand of misogynist thought, and suspicion of female participation remained strong well into the $19^{\text {th }}$ century. But while revolutionary ideas about women's role within the ancien regime are so complicated as to make anything but the briefest summary outside the scope of this thesis, revolutionary concepts of masculinity betray an extraordinarily high level of faith in the power of the political expression of male-ness. The idea that the fall of the monarchy allows the appearance of genuine masculinity onto the political scene very strongly implies that an anti-masculine force is removed along with the monarchy, and an anti-masculine force can only be regarded as effeminate. This concept is illustrated by the constant criticism of central figures of the monarchy as effeminate - revolutionary depictions of Louis XVI as impotent are an attempt to take the narrative of personal impotence (and thus inability to project power into the future as explained above) and apply them to the monarchical institution as a whole.

Tyranny and the French Monarchy:

To the modern day reader 'tyranny' and 'absolute monarchy' may seem to go together. This may be partly because the term 'tyranny' has a less solid grounding in political theory than 'nation' or 'gender' do. While an extensive discussion of exactly what is meant by tyranny will have to wait until chapter six of this thesis, this essay will broadly use a definition of tyranny as a concept of 
government that is personal and arbitrary. With this definition in mind, from a contemporary perspective, it is hard to imagine that those who knowingly submitted to the rule of a monarch who based his legitimacy on a combination of divine right and personal dominion over the state as being sensitive to critiques that his rule was tyrannical. But this was not the case.

Royal government was usually sensitive to the need to protect, or at least be seen to be protecting, the rights of the state's subjects. In 1789 a cahier directed to the royal person by the townspeople of Lauris, in the south of France, on the occasion of the summoning of the Estates General asked the King to '(Make) us happy; your peoples; at the mercy of despots; throng to take refuge at the foot of your throne and come to you seeking their tutelary god, their father, and their champion' ${ }^{24}$ The King is seen not only as not being a tyrant himself, but as being a potential agent of his subject's emancipation from tyrants.

Tyranny was a term much bruited about during the $17^{\text {th }}$ and $18^{\text {th }}$ century and was rarely defined in a satisfactory manner. It had implications of orientalism and violence, but the definition offered by Rousseau is the most informative:

"In vulgar usage, a tyrant is a king who governs violently and without regard for justice and law. In the exact sense, a tyrant is an individual who arrogates to himself the royal authority without having a right to it." ${ }^{25}$

If we combine these 'vulgar' and 'exact' concepts of tyranny there are three main concepts involved - violence, lack of respect for the law, and illegitimacy. Given that the people would only actively resist an illegitimate ruler, the concept of violence can be collapsed into illegitimacy, and given that

${ }_{24}$ Chartier, Roger, Cultural Origins of the French Revolution., trans Lydia Cochrane, Duke University Press, Durham, 1991, p113

25 Rousseau, Jean, "The Social Contract' in The Social Contract and the Discourses, trans GDH Cole, Random House, London, 1993, p256 
Rousseau saw respect for the laws of the people as a prerequisite for legitimate rule, we are left with only a single definition - a tyrant is a ruler who does not respect the laws and rights of his subjects; tyranny is the practice of disregard for law.

One might debate as to whether or not any given action taken or policy created by the royal government was tyrannical but it is interesting to note that even, indeed especially when extending a policy that might be interpreted as constituting tyranny, the government did its best to issue denunciations of tyranny as a practice, even if not always explaining satisfactorily how its current policies were not the tyrannical ones they seemed to be. This shows quite strongly that the monarchy did not wish to see itself as practicing tyranny.

Obviously anti-monarchists took a different view, and the narrative of the ancient regime as one of tyranny was that which was most consistently and openly advocated during the revolutionary period. Examples are too numerous for more than a small sampling to be given, but St Just's statement negating the ability for a King to be an innocent is perhaps the best example. The Abbe Gregoire agreed, stating that 'dynasties have never been anything but voracious breeds living off human flesh'. ${ }^{26}$ Even St Just's political opponents among the Girondins had little positive to say about the monarchy when it came to the need to protect the rights and liberties of the French. The main difference between the two groups seems to have been not that one had a less harsh view of the monarchical institution than the other, but that one felt all that needed to be done was to strip away the monarchy to reveal the natural (and national) liberties and freedoms of the French state, while the other felt that more positive work needed to be done to build them, and suspected their political rivals of attempting to whip up anti-monarchical fervour as a strategy for short-term political gain. ${ }^{27}$ Even during the early stages of the revolution, attempts to reconcile the monarchy

26 Dunn, p17.

27 Dunn covers this dispute thoroughly in her discussion of Girondin and Jacobin attitudes towards the 'sacrifice' of Louis XVI. Dunn, pp17-22. 
with non-tyrannical government were at best treated with scepticism, although the Tennis Court Oath's reference to 'true monarchy' as complementary to a constitution seems to imply openness to reconciliation of the two positions.

Nationalism and the Russian Monarchy:

The major obstacle for nationalists in Czarist Russia was that the state as constituted did not represent a wholly or even mostly Russian entity. Less than half of the Czar's subjects spoke Russian and not much more than half of them were Orthodox Christians. Although Orthodox Christianity offered a potent legitimising factor for the regime it was generally seen as insufficient to bear the weight of national identity alone, something clearly illustrated by official attempts to Russify several non-Russian minorities. The fact that the state was majority Orthodox was not enough; it had to be majority Russian too. ${ }^{28}$ References to the ancient tradition of Russian autocrats such as Ivan the Terrible and Peter the Great can be expected to have had little positive resonance for the Empire's Islamic or Polish-Catholic subjects respectively. It is true that these figures were often depicted as dynastic forebears of the Czars as much as they were leaders of the Russian nation, but it is difficult to see the Czar's resurrection during the Romanov tercentenary of Muscovite methods of dress and ceremonial as anything other than attempts to impose a more authentic Russian national tradition on the people from the top down.

In contrast to the very real, if difficult to pin down, French concept of the 'authentic constitution', no Russian politicians proposed the existence of a traditional Russian constitution; that is, no framework for a process of dispute arbitrage between the people and the state that could be said to

28 Despite this, Orthodoxy was considered to be a precondition for authentic Russian nationality, and most Russian claims that Ukrainian (or, to use the terminology of the day, Malorusski/Little Russia) nationals were in fact Russian depended on Kiev's status as the original centre of Orthodoxy in Russia and a claim that Saint Vladimir had been a Russian, not Ukrainian figure. For further discussion of this, see Theodore R. Weeks, Nation and State in late Imperial Russia: Nationalism and Russification on the Western Frontier, 1863-1914, Northern Illinois University Press, Dekalb, 2008, pp33-4. 
be authentically Russian. Indeed, monarchists conceived of authentic Russian relations between the governed and the governors as entirely one-way, the best interests of the people being served not by their ability to represent themselves but by the personal good judgement and diligent consideration of the Czar. When discussing national identification in ethnically mixed areas of the Empire, Russian commentators frequently discussed a group's 'love, gratitude and devotion' to the Czar. ${ }^{29}$ The most profound ideological program for the Russian monarchy was that laid out by Sergei Uvarov, education minister under two Czars, stipulating 'Orthodoxy, Autocracy and Nationality', but the nationalism Uvarov proposed, and which his conservative ideological heirs continued to abide by, was a limited one concerned almost exclusively with heritage, not an embrace of a vibrant, present-oriented national community. ${ }^{30}$ When the Russian state invoked nationalism it equated the Russian 'nation' with the Russian Imperial state, despite the fact that there was manifestly no nation to match the state's extent.

After the revolution of 1905 a liberal constitutional tradition, centred around the Kadet party in the Duma, did emerge. But it was one that owed a great deal to foreign influence, particularly French influence. Although Russian liberal nationalists such as those that supported the Kadet party could be said to be monarchists in that they envisaged a political program that reserved a central role for the Czar and afforded him significant powers, they could not be said to be nationalists in the sense that French constitutional monarchists of the revolutionary era were. Unlike Mirabeau and the Girondins, they saw modernity not just as a source of energy which could revive the ancient, valorised and above all national political/legal system temporarily enervated by corruption and ill will, but as a transformative element. In other words, they wished to take the next step in what they saw as the historical progression of Russian government - a step they felt was long overdue. This modernism was effectively a repudiation of nationalism as decisive as that affected by Uvarov,

\footnotetext{
29 Weeks, p57

30 For more on Uvarov's ideology and its place within Russian conservative thought, see Whittaker, Cynthia H. 'The Ideology of Sergei Uvarov' in Russian Review, Vol 37, No 2, 1978, pp158-76.
} 
albeit in a very different direction. This is best illustrated by the fact that Prince Lvov, the first prime minister of the liberal government, chose to have his visiting cards printed in French. ${ }^{31}$ In considering the position of Russian anti-monarchists on the national status of the monarchy, or indeed on any aspect of the monarchy, one realises that there are both reasons for optimism and pessimism in comparison to their French counterparts. Unlike the French groups that overthrew the Bourbons, the anti-Czarist groups who removed the Romanovs did not coalesce at the moment of revolution but substantially before it. Less happily for the analyst, anti-Romanov forces were even more philosophically divided than their French counterparts. Although Jacobins, Girondins and other groups contended fiercely and violently in France, their ideological disagreements were confined to a relatively narrow spectrum - the most moderate Girondin and the most fervent Jacobin were both essentially believers in Rousseau's national liberalism. In contrast, the Russian anti-Czarists came in two extremely distinct flavours - the liberalism of the zemstvo, the February Revolution and the Provisional government, broadly consistent with their French counterparts, and the revolutionary Marxists of the October Revolution and the Soviets. Although these two groups disagreed vehemently (not to say violently) on any number of issues there were commonalities in their opposition to Czarism and whenever possible this thesis will attempt to identify a single oppositionist critique.

Unsurprisingly one of these commonalities was that both Bolsheviks and Liberals saw the Czars as an inauthentic representation of the nationalities present in the Russian Empire. Somewhat surprisingly neither group saw fit to criticise the fact that the family of Nicholas II used English in their domestic life, despite the fact that the personal history of Imperial family members became a major factor in public perceptions during the revolutionary period. ${ }^{32}$ However, other manifestations of Czarism's perceived non-nationality were fair game. During the late $19^{\text {th }}$ century many leftist

\footnotetext{
$31 \quad$ Figes, pp357-8.

32 Weeks, p12
} 
thinkers, mostly evoked by self-identified populists, implicitly saw Czarists as introducing a foreign, non-national element in the form of capitalism into the Russian peasant economy. These thinkers tended to see Russian peasant society as a model for a post-capitalist economic order. ${ }^{33}$ This idea was paralleled by conservative groups who had become disenchanted with the post-1905 flirtations with liberalism, although ironically at this stage the left had largely abandoned what might handily be termed a 'left-conservative' concern for traditional economic relations. Although few of these conservatives were involved with the liberal groups, let alone the Bolsheviks who removed the Imperial family from power, they did contribute strongly to an anti-national critique of Czarism, essentially picking up (although probably not consciously) this tradition of nationalist anti-capitalism from their populist predecessors.

One would expect the socialist parties to be strongly opposed to the principle of nationality, and it is certainly clear, as Gellner points out, that nationalism is difficult to reconcile with the writings of Marx. ${ }^{34}$ In practice the picture was much less clear. It is true that socialists were generally tolerant of the demands of non-Russian groups to obtain autonomy within the Russian Empire or even secede from it. ${ }^{35}$ However an indulgence of non-Russian nationalism does not necessarily translate to a position that opposes Russian nationalism, particularly when the position does not need to be translated into the zero-sum game of actual political power. It is certainly true that when the Bolsheviks took power their tolerance of non-Russian nationalism was limited, but even before then many Bolshevik revolutionaries, particularly in the armed forces, used explicitly nationalist rhetoric to support a socialist program for Russia. 'German' became a byword for everything negative about the status quo - the suffocating influence of the court, the profiteering of capitalist captains of industry, the brutal punishments levied by officers, even while actual Germans, at least in the form of the German soldiers and prisoners of war whom Russians came into everyday contact with, were

\footnotetext{
33 Figes, Orlando, pp84-121.

34 Gellner, Ernest, Nations and Nationalism, Ithaca, New York, 1983, p129

35 Weeks, pp22-4.
} 
often viewed with sympathy. ${ }^{36}$ Similarly Lenin resorted to metaphors of foreign-ness when criticising the Russian bureaucracy, describing it as 'Asiatic' and 'Chinese'. ${ }^{37}$

\section{Gender and the Russian Monarchy:}

Monarchy in Russia was a deeply sexist institution. Depictions of the Czar as a divine intermediary or a 'little father' to the Russian people both encouraged Russians to equate their monarch with institutions - the orthodox Church or the nuclear family, respectively - that their experience would inform them as exclusively male dominated. Everything that has been said above about the patriarchal nature of hereditary agnatic succession in France, and the assumptions about male power, applies equally to Russia. The major exception is that Russia did not explicitly exclude women from becoming monarchs. There had been two principal Czarinas in Russian history, and one of them, Catherine the Great, was generally seen as a positive model for monarchy, belonging to the elite pantheon of 'good monarchs' that also encompassed Peter the Great and Ivan the Terrible and was regularly invoked by monarchists who needed a concrete person to illustrate their ideas of benevolent monarchy. This meant that in one important aspect the conceptual world of the Russian monarchy was more open to women than its French counterpart.

Conversely there was no habit (it would be an exaggeration to say 'tradition') of political influence by the monarch's sexual partners of the sort that existed in France. The sexual lives of Russian Czars are more obscure than their French counterparts although it would be wrong to assume that they all practiced the diligent family life that they promoted to their subjects. But the position of mistress to the Czar was not even informally a political one, as it became in France. Any service rendered by these hypothetical Czarist mistresses was exclusively sexual. It is worth noting that

\footnotetext{
36 Figes, p414

37 Burbank, Jane, 'Lenin and the Law in Revolutionary Russia' in Slavic Review, Vol 54, No 1, Spring 1995 , p29.
} 
during periods of female Czardom, most notably that of Catherine the Great, the opposite was true; Catherine's lovers almost all aspired to some form of political role, not least Prince Potemkin, who was able to use his sexual access to become a powerful regional governor and effective prime minister. This meant that while the Russian monarchy was open to women at the very top, unlike the French institution, it offered no path to female power through any direction other than succession. A tradition of influential female court figures is entirely absent from Russian history.

Bolshevik rhetoric was extremely pro-woman/feminist and strongly criticised the monarchy for repressing women. Russian progressive thought had always had a very strong feminist component during the $19^{\text {th }}$ century, and it was from this milieu that the Bolsheviks arose. ${ }^{38}$ This pro-feminist genesis strongly informed Bolshevik rhetoric on the issue of women's rights. The alliance between bolshevism and feminism should not be overstated; although socialist groups attended most major Russian conferences addressing the 'woman question' they usually did so with the explicit purpose of downplaying women's issues as anything other than a facet of the general issue of overthrowing the Imperial state.

These conferences provide a surfeit of information concerning both liberal and socialist views on the possibilities for women under the Imperial monarchy. Although there were differences, sometimes violent, between liberal feminists over attitudes towards and accommodations with the Imperial government, and the threat of provoking further repression in sensitive times by taking too harsh a stance should not be underplayed, it nonetheless seems extremely significant that no Russian feminists other than members of revolutionary political parties seem to have suggested that monarchy was incompatible with feminism. Calls for the end of the monarchy seem to have been restricted entirely to socialist delegates to feminist gatherings and it was these calls that made them marginal figures.

38 Edmondson, Linda Harriet, Feminism in Russia, Stanford University Press, Stanford, 1984, p9. 
In the modern era tyranny and absolutism are conflated and it is tempting to see Nicholas' proud proclamation of absolutism before 1905 as a positive embrace of tyranny. It is true that fear of tyranny as an abstract principle does not seem to have animated the political consciousness of Russian nobility and opinion leaders to the same degree it did their French counterparts prior to their revolution. However the Russian monarchy was alert to the criticism that it trampled on the rights of its subjects and, while the actual commitment to the principle of preventing tyranny could be doubted, it is not in doubt that monarchist apologists attempted to avert this criticism wherever possible. When numerous calls were made for representative institutions such as an assembly or responsible government the monarchy's response was not that it had no desire to grant the freedoms these institutions were designed to provide, but that the freedoms were already provided. However, these freedoms were usually formulated as the result of the Czar's careful attention, so it is difficult to conceptualise this as a true commitment to granting freedom, and thus opposing tyranny, as an absolute principle.

After the revolution of 1905 the Czarist monarchy attempted to establish limited principles of constitutional government similar in spirit to those initially advocated during the French Revolution. However this attempt to put into effect semi-liberal, anti-tyrannical measures such as the Duma and the Council of Ministers was not an attempt to redefine the monarchy itself. Part of the reason these institutions and legal forms could not be respected by conservatives was that the monarchy was unable to reconcile them with its own self-image. ${ }^{39}$ The monarchy remained unable to incorporate any idea of rights into its self-presentation, let alone its self-conception, and was thus unable to clearly explain why existing institutions existed. Although many historians have pointed

39 For an in-depth discussion of conservatism scepticism towards the post-1905 order in Russia, see Mikhail Loukianov, 'Conservatives and “Renewed Russia”', 1907-1914' in Slavic Review, Vol 61, No 4, 2002, pp762-786. 
to Nicholas' personal encouragement of anti-democratic groups such as the Black Hundreds, this personal naïvete on the Czar's part was less consequential than incompatibility with the concept of absolutism. This problem was institutional and certainly predated Nicholas' regime - it was also responsible for the failure of the zemstvo local councils instituted in 1870 to enhance the ability of ordinary Russians to throw off the onerous restrictions the Czarist regime imposed on their liberty. ${ }^{40}$ The question of personal rights as related to government is the area in which it is most difficult to identify a common critique among liberal and Marxist anti-revolutionaries. In common with the European $19^{\text {th }}$ century liberal tradition which they so consciously saw themselves as part of, Russian liberals saw personal rights as central to effective government. In contrast, and again in accordance with a broader European tradition, Marxists saw individual rights as secondary to the need to maintain class solidarity. There was seemingly little commonality between these two groups, and it is certainly true that in terms of theory they shared little. Indeed, in many cases their stances on issues of rights were further from one another's than from that of their shared Imperial foe Bolsheviks, for instance, called for the abolition of private property, while both liberals and Czarists wanted to preserve it. However in practice, there was a degree of commonality that provides fertile grounds for analysis.

Thus, Bolsheviks and Mensheviks were more than willing to use language derived from the rightsbased critique of imperial government to critique Czarism. Many on the left adopted what may be seen as the classic Marxist view that Russia had not yet entered a stage of bourgeois capitalism, and that this stage, while still unsatisfactory, would be preferable to that offered by Czarism. The bourgeois capitalist model was one of constitutional monarchy or republicanism, of freedom of speech and political participation; in other words, it was a society of rights either implicitly or explicitly similar to those existing in Western Europe. Even Lenin, while he frequently denounced

40 This is not to say the zemstvo councils were ineffective; they did make a major difference in the provision of poor relief, and they provided a nursery for the liberal intellectuals who would go on to rise to national power after the 1905 reforms. For a more complete description of the operations of the zemstvos, see Alan Wood, The Romanov Empire 1613-1917, Hodder, London, 2007, pp266-71. 
bureaucracy and "chancellery formalism", and harshly attacked socialists who saw the "rule of law" as a goal rather than a "temporary expediency", on some occasions attacked the Czarist state and the bourgeoisie who he saw as its true constituents for failing to live up to its own laws. ${ }^{41}$ While socialists instinctively wanted to attack the Czarist state on class-based terms it was often tempting to do so by drawing attention to its denial of legal rights - in effect criticising it for not being procapitalist enough.

For their part, Russian liberals had a much less problematic relationship with a rights-based criticism of the Czarist state; indeed, this proved their main critique. When the liberals came to power their legislative program was based, as we shall see in later chapters, on addressing rightsbased criticisms of the Czarist state. But liberal criticisms of Czarism were not limited to those implicit in their own positive program. During the post 1905 period liberals focused on promoting laws that granted rights, both positive and negative, to the Czar's subjects, and in holding the government to account for perceived failings to implement or respect these laws. In the pre-1905 period the liberal project remained essentially identical but focused on local government rather than the Duma. It could be argued that none of these groups saw Czarism as innately conflicting with a rights-based polity, and thus that Czarism was not innately tyrannical, but the movement towards constitutional monarchy does seem to have implied, at best, that Czarism could not be trusted to monitor its own rights abuses and that a tendency towards tyranny was implicit in its makeup.

41 Lenin seems to have been particularly eager to make rights-based critiques of Czarism prior to 1905. Burbank, pp23-44. 


\section{CHAPTER TWO: \\ GENDER AND FRANCE}

Of all the ways in which Marie Antoinette was criticised, her gender is perhaps that which looms most obvious to the casual observer. She surrounded herself with the accoutrements of femininity, identified herself firmly and unambiguously as a woman, and had risen to prominence through a role specifically reserved for a woman. In contrast, her status as a foreigner was relatively underplayed and her status as a tyrant was something that had to be constructed by her enemies. Marie Antoinette's status as a woman was obviously crucial to her becoming queen. While the queenly office represented an opportunity to consolidate foreign alliances, its core function was delivering a legitimate child to the king. For the queen to be a foreigner was desirable, even de rigueur, but it was not necessary. A French queen would have raised eyebrows, while a male queen would have been (and still is) regarded as ridiculous. It is therefore appropriate that any analysis of critical narratives of Marie Antoinette begins with her status as a woman, by looking at narratives that are defined by gender.

It would be an over-simplification to say that Marie Antoinette's identity as a woman was as problematic in and of itself as her identity as an Austrian or a tyrant. Although her gender was less ambiguous than her nationality or tyranny, it was also not as innately repellent to the revolutionary narrative. It was plausible (if impractical) to call for all foreigners to be proscribed, or for tyranny to be ended, but to call for all women to be proscribed was not. A France without foreigners or tyrants was conceivable, if only in a distant and utopian manner, but a France without women would obviously not function as a society for long. Criticisms that relied on Marie Antoinette's femaleness therefore had to focus, not simply on her status as a woman, but as a woman who was somehow acting inappropriately. 
Any reader who considers what 'acting inappropriately' might mean is likely to find their mind turning towards sexual behaviour, and if they were to read ahead with this expectation they would be unlikely to be disappointed. Indeed a brief review of this chapter might lead one to think that this is a discussion, not of the public idea of Marie Antoinette's gender, but of her sex life. It is certainly true that extensive consideration will be given to the idea of Marie Antoinette as a sexual being. Without wishing to delve too deeply into attitudes of the time towards what it meant to be a woman or a man, it is probably sufficient to say that the distinction between a 'woman' and a 'bad woman' seems to have relied on norms of sexuality. That being said no review of the manner in which Marie Antoinette was perceived as deviating from the revolutionary ideal of what it meant to be a good woman would be complete without looking at extra-sexual critiques, such as those that accumulated around Marie Antoinette during the Diamond Necklace Affair and its aftermath.

The ideal role of women in revolutionary and pre-revolutionary France:

Ideas about exactly what was and was not appropriate behaviour for a woman were a constant feature of public life throughout the revolutionary period. Although a counter-narrative existed in what we can tentatively identify as the 'feminism' of the day ${ }^{42}$, the pseudo-official position as expressed by the revolutionary authorities was that the appropriate place for a woman was the home, and her only possible contribution to public affairs was to support her husband in order that he might better fulfil his own responsibilities as a public man. For this reason, this chapter could more precisely but less elegantly be termed 'Marie Antoinette as a bad woman'. We will look at how Marie Antoinette was viewed as a woman who behaved in ways that were unacceptable for a woman to behave, but still identifiably feminine. In doing so we will bear in mind Vivian Gruder's point regarding the need to draw a clear distinction between depictions of the queen that predate the

\footnotetext{
${ }^{42}$ Perhaps the best example of such pseudo-proto-feminism is the writing of Condorcet, who saw female rights as human rights. Sagan, Eli, Citizens \& Cannibals: The French Revolution, the struggle for modernity, and the origins of ideological terror. Rowman \& Littlefield, Lanham, $2001, \mathrm{p} 392$.
} 
Revolution and depictions that coincide with it. ${ }^{43}$ To do this we also need to understand the concept of the ideal woman to which Marie Antoinette was unfavourably contrasted.

Jean-Jacques Rousseau, as has been mentioned above, was often seen as the intellectual founding father of the French Revolution. Rousseau's view of women was not one that was consistent with feminism; he advocated a role for women largely consistent with what would become the revolutionary ideal of the supportive, housebound wife. While Rousseau was the originator of revolutionary ideology a deeper investigation of Rousseau's ideas on women may not be rewarding. Such a survey of Rousseau's thought might be satisfying for other reasons, but it is unlikely to be helpful in this case because the role of Rousseau's thought in forming the ideology of the Revolution can be and has been strongly overstated. Blum argues that Rousseau the ideologist was less important to the revolutionaries than Rousseau the man, whose life offered a model of resistance to tyranny, and whose philosophical writings were important chiefly in the way they enraged authority rather than their content. ${ }^{44}$ While many of the revolutionaries who approvingly spoke of Rousseau might have read his works, it is unlikely that they thought first (or even at all) of his ideas when implementing policy. As Marisa Linton memorably summarises, 'it was the Revolutionaries who created Jean-Jacques Rousseau as the founder of the Revolution'. ${ }^{45}$ Therefore, a study of Rousseau's ideas on gender is best left for other works; while it is certainly a fertile field of enquiry for broader studies of the history of gender identity and roles in society, it tells us relatively little about the ideas of the revolutionaries themselves. Any similarities between Rousseau's ideas of femaleness and those advocated by the revolutionaries are likely to be fairly superficial and not a result of lineal ideological descent.

43 Gruder, Vivianne, 'The Question of Marie Antoinette: TheQueen and Popular Opinion Before the Revolution' in French History, Vol 16, No 3, Oxford University Press 2002, pp269-70.

44 Blum, Carol, Rousseau and the Republic of Virtue: The Language of Politics in the French Revolution., Cornell University Press, Ithaca, 1986, pp31-6.

45 Linton, Marisa, 'The Intellectual Origins of the French Revolution' in The Origins of the French Revolution, ed Peter Campbell, Palgrave MacMillan, Basingstoke, 2006, pp143-4. 
It is necessary, therefore, to reach for less self-consciously ideological, more everyday, 'earthier' models of womanhood to discern the revolutionary view more clearly. As we have seen the concept of the nation as a family was one that appealed to the revolutionaries. If kingship could be imagined as the nation having a father, then a queen, presumably, would be the mother. Although this metaphor was intended to educate the French on how the nation should be, it also gives remarkable insight into the concept of the family, and particularly women within the family. This idea of the family as a guide to the ideal form of political life was not unknown at the time. Marie Antoinette's own mother, Maria Theresa, successfully demanded the fealty of the Hungarian Diet by presenting herself as a mother, complete with her children in attendance. ${ }^{46}$ In France, women, as we have already seen, were able to partly bypass the otherwise rigid prohibitions of the Salic law on female power by presenting themselves as exercising the role of a mother. Even Marie Antoinette herself, when placed on trial by the revolutionaries, offered as her final defence a portrayal of herself as a mother and a plea for maternal solidarity. ${ }^{47}$ The maternal image was a powerful one and provided the role of the 'mother' that Marie Antoinette and her contemporaries tried to use.

For many French peasant families, children were raised by a single woman within a multi-family group, by a woman who was not necessarily their biological mother. ${ }^{48}$ The tasks that made mothers unavailable to raise their children might be the societal obligations of a wealthy mother who employed servants to feed and nurse her children, or the economic tasks of a woman engaged in a village economy who engaged neighbours and extended family to care for her children. The mother's role was in some ways analogous to that of a monarch - she reigned over the polity that was her children, providing legitimacy and big-picture guidance about what they wore, ate and learnt, but she did not engage in those tasks herself, particularly once they had become routine. It is

\footnotetext{
46 Although Maria Theresa had to also promise the Hungarian magnates substantial concrete concessions, the rhetoric of motherhood which she used nonetheless gave them the political cover they needed to seek these concessions in return for their obedience without appearing to subordinate themselves unduly.

47 Fraser, Antonia, Marie Antoinette, Weidenfeld \& Nicholson, London, 2001, p404

48 Simonton, Deborah, European Women's Work: 1700 to the Present, Routledge, London, 1998, p25.
} 
worth noting, however, that these substitute child-rearers were explicitly female. This demonstrates that while raising children was women's work, it was not necessarily a mother's.

When the act of childrearing is stripped away the role of the mother becomes a purely generative one - she may not raise the children, but she bears them, and this generative role is politically significant. We have already seen in chapter one the crucial position of the queen in providing the dynastic continuity that is the sine qua non for dynastic governance. The revolutionaries, as Carole Pateman asserts, sought to create a society where the ultimate generative function - that of the nation - was controlled by men, a form of political if not actual 'male birth'. ${ }^{49}$ In France it was necessary to discredit and dismiss the prior model of legitimacy-generation and replace Marie Antoinette's conventional feminine national birth, (a model which more closely paralleled biological fact), with their own.

One of the main precepts of the queen's trial was the accusation that her interference with the dauphin sabotaged the national future he represented. While it is unlikely that placing a Louis XVII on the throne, even as an extremely weak constitutional monarch, was seriously contemplated by revolutionary politicians during the time of Marie Antoinette's trial, the motives that they imputed to the queen were portrayed as contrary to public interest. The trial was not about a mother abusing her child but about the dauphin representing the French nation. The queen that appeared in the prosecutor's briefs during the trials was different to the sexually omnivorous and permanently rapacious 'Hebe' of La Godmiche Royale. Rather than subordinating political goals to sex, the prosecutors argued, Marie Antoinette had used her sexuality as a political tool in the hope of 'enervating' the dauphin and, in doing so, the French nation. ${ }^{50}$ This was paralleled by a wave of pamphlets that accused her of weakening her son through non-sexual means, such as poison. ${ }^{51}$

49 Pateman, Carol, Sexual Contract, Stanford University Press, Stanford, 1988, pp89-90.

50 Hunt, The Family Romance of the French Revolution., p101.

51 Thomas, Chantel, The Wicked queen: The Origins of the Myth of Marie-Antoinette, trans Julie Rose, Zone Books, New York, 1999, p133 
When she defended herself as a good mother, Marie Antoinette was effectively, if not knowingly, defending herself as an appropriate custodian of the French nation. This conflation of motherhood with the birth, and thus the rebirth and maintenance of the nation, is one of the many collisions of gendered and nationalist concepts that will continue to manifest themselves throughout this thesis.

Deviations from the norm - Marie Antoinette as masculine:

One particularly pervasive line of critique of Marie Antoinette as a woman reversed the revolutionary theory of gender politics. The idea that only men possessed the natural characteristics necessary to participate effectively in political life was firmly grounded in France, as can be seen through the writing surrounding the Salic law. Despite her protests of political neutrality and impotency, Marie Antoinette's detractors saw her as participating in politics. There were only two ways to reconcile these ideas. On the one hand, the queen could be portrayed as ineffective, but this was implausible to her critics. The revolutionaries' need to portray themselves as heroic figures engaged in a defining struggle created a consequent need for their their enemies to be strong, something seen in the Jacobins' attribution of semi-mystic properties to Louis when calling for his execution. Alternatively, Marie Antoinette could be perceived as powerful if she was also depicted as having acquired or assumed the masculine traits necessary for that effectiveness.

Masculinisation of women was viewed unfavourably in the French political tradition. Michelet's portrayal of Joan of Arc cutting away her hair is a positive allusion to a woman becoming more masculine, but the cult of Joan is a $19^{\text {th }}$ century Conservative-Republican ideology that post-dates the time of Marie Antoinette. To find positive images of women impersonating men in the prerevolutionary period is significantly harder, and to find them during the revolutionary transition is near impossible. On the other hand, finding concern and disquiet, not to say anger, surrounding the 
idea of masculinised women, is easy. Rousseau warned that woman fulfilling masculine roles would feminise men. ${ }^{52}$ The Marquis de Sade wrote of women becoming men in La Philosophie de la Boudoir as part of the general context of a breakdown of sexual propriety. ${ }^{53}$ Marie Antoinette's own mother, Maria Theresa, was denounced as an 'amazon' in D'Anglincourt's Ode a la France. ${ }^{54}$ Parallel panic about the concept of men becoming feminised existed, but concern about women becoming masculine seems to have gone beyond a general worry about the blurring of gender boundaries to specific fear of masculine women. The revolutionary patriot Louise de Keralio, as part of her criticism of monarchs, asserted that a woman who became King would have to change sex - which could have been seen as the ultimate expression of alarm at the concept of masculine women. ${ }^{55}$

One of the main ways in which the queen was portrayed as having masculine traits was a popular tradition that depicted her as enjoying sexual relations with other women. The number of pamphlets, broadsheets, false 'confessions' and other published allegations is beyond cataloguing. Even the most casual study of the pamphlet literature depicting Marie Antoinette will quickly reveal a single overwhelming theme - that of sexuality. Pamphlets appear depicting the queen of France engaging in a wide range of sexual activites with almost all her acquaintances or intimates except (notably) her husband. The pamphlet literature has been surveyed extensively elsewhere, and a full review of it is beyond the scope of this piece. ${ }^{56}$ Attention can nonetheless be usefully drawn to probably the most famous single pamphlet, La Godmiche Royale ('The Royal Dildo'). La Godmiche depicts a very thinly disguised Marie Antoinette, identified as 'Juno', cavorting with her

52 Hunt, The Family Romance of the French Revolution, pp90-1.

53 Sade, Marquis de, La philosophie dans le boudoir, London, 1795, pp247-8. Without doing more than acknowledging the existence of the extensive literature concerning de Sade's ideas on gender, which it is accepted are complex, the context of the discussion of masculinisation as apropos of sodomy and incest was probably seen by the average French reader as less than an endorsement even if Sade's intent in writing it was less clear cut.

54 Kaiser, Thomas, 'Who's Afraid of Marie Antoinette?' in French History, Vol 14, No 3, 2000, p244

55 De Keralio, Louise-Felicite Guinement, Les Crimes des Reines de France, Bureau des revolutions de Paris, Paris, 1791, p vii.

56 An excellent starting point is Jack Censer's 'France 1750-1789' in Press, Politics and the Public Sphere in Europe and North America, 1760-1820, Hannah Barker and Simon Burrows eds, Cambridge University Press, Cambridge, 2002, pp159-78. Hugh Gough's 'The Revolutionary Press' in the same volume is also useful, pp182-96 
assistant, 'Hebe', usually seen as corresponding to the either the Duchesse de Polignac or the Princesse de Lambelle, two of the queen's close associates. In La Godmiche both Hebe and Juno are depicted, not as lesbians in the sense that we understand it today: that is as people who are exclusively or even primarily attracted to women, but as sexually voracious and utterly indiscriminate. Their supposed liaison with one another is not so much intended to cast one or the other in the role of a man as to demonstrate their willingness to abandon all social mores surrounding sex. Despite this, traditional notions identified the sexual initiative as belonging to men. So these depictions of sexual predation and fervor would have been seen as masculinising. It is also worth noting LaQueur's conclusion that in the early modern era the active woman in a lesbian sexual partnership - the tribade - was seen as acting in an unnatural fashion, while the passive partner did not face opprobrium. ${ }^{57}$ It is no great leap to see masculinity one of the traits that makes the tribade unnatural. Marie Antoinette's detractors obviously adhered to this theory, as she was always presented as the rapacious, aggressive partner and, even when the sexual act was not depicted, as the more actively desiring of sex.

ntoinette in the pamphlets:

Of course such depictions of diverse and enthusiastic sexual encounters did more than simply portray the queen as masculine. Her primary function was to provide an heir to the throne, so to portray her as sexually engaged with a wide range of people was to call into question her ability to correctly perform the task that the office existed to justify. To use this as an explanation for $L a$ Godmiche and its ilk is to imply that the authors were animated by an entirely legitimist concern for the monarchical succession, which is not the case since both they and their readers were eager to overthrow the monarchy. But it is a dimension that cannot be escaped in considering depictions of

57 This is almost the exact opposite of the situation among homosexual men, where the passive partner is seen as transgressing while the active partner is not, for the same reason - the active man and passive woman are fulfilling their sexually correct roles while the passive man and active woman are not. LaQueur, Thomas, Making Sex, Harvard University Press, Cambridge, 1990, p136 
Marie Antoinette's sexuality if only because it provided a cover for less public-spirited examinations of her activities in the bedchamber.

When Marie Antoinette first entered the public eye as dauphine it was in the context of a court that was well known for its sexual laxity. Although the queen was acknowledged for her piety, she had been dead for two years and the central female figure in the court, who essentially set the tone for what was expected of the women who attended the King, was Madame Du Barry, Louis XV's mistress. Du Barry was a successor to Madame Pompadour in the King's bed but she was a less substantial figure, both intellectually and politically, than her predecessor. Her common birth, her lack of interest in courtly politics and her excessive (even in the context of Versailles) desire for luxury made her offensive to much of the court. On her arrival in France Marie Antoinette was seen by many commentators concerned over the sexual compromise of the monarch in the form of Madame Du Barry as an innocent, wholesome antidote; a 'good woman' to counter Du Barry's 'bad woman'. ${ }^{58}$ It was a role the dauphine embraced, publically snubbing Du Barry in Versailles even after being informally asked by the King to extend some favour to her.

The 'good woman' image did not endure. By the time of the Revolution the queen's public image had become the mirror image of what it had been when Du Barry was her defining opposite. Profuse pamphlet literature presented her as a woman defined by sexual immorality. In $L a$ Godmiche Royale, the piece de la resistance of the genre, the queen masturbates, uses sex toys, has lesbian sex with one of her household attendants and advocates incest. ${ }^{59}$ In L'Autrichienne en Goguettes the queen indulges in sex with her husband's younger brother, the Comte d'Artois, and Polignac simultaneously, passively offering herself to them as they quarrel over her body ${ }^{60}$. In Essaies historiques sur la vie de Marie-Antoinette she displays her lactating breasts to passers-by. ${ }^{61}$

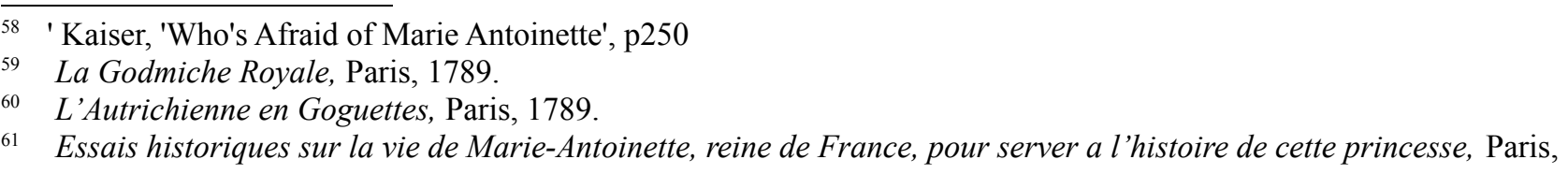


These pamphlets can be considered both pornographic and political. La Godmiche goes into so much detail concerning sex acts that it is possible to conclude it was intended as pornography with a political flavour to lend it a competitive edge over its presumed apolitical competitors. Large sections of the pamphlet are devoted purely to endorsing the virtues of constant sex with anybody available, a sentiment that it is difficult to view as political (at least in the narrow sense of the word) simply because it is imputed as coming from the mouth of a thinly disguised Marie Antoinette. $L a$ Godmiche is not alone in its pornographic goals. Although the authors of La Godmiche and its associated works are obscure it is uncontroversial to presume that their most immediate intention was not to propagandise but to make money, because the pamphlet trade was very successful and profitable. The pamphlets' producers' theories were centred around what Parisian buyers would want rather than theories about Marie Antoinette's role in the state. Their degradation of the queen existed because they felt their readers wanted to see her degraded. Their theories were substantially correct, since the pamphlets sold well and were circulated widely.

We can see there was an appetite for political literature, and more specifically political literature that was hostile to the queen. It is tempting to simply dismiss the first point - the hunger for sexual literature that need not be political - as irrelevant, at least for the purposes of this thesis. But the desire for sexual literature itself is revealing. Many pornographers drew connections between the breakdown in sexual proprietary that they perceived and chronicled and a corresponding breakdown in public morality. ${ }^{62}$ Furthermore, the sexuality of the queen is rarely presented as something that should be enjoyed. Although the depiction of the sexual act appealed to some readers, commentary on the matter is either derisive or involves praise so excessive as to be inaccessible to the average reader. In La Godmiche Marie Antoinette's doppelganger proclaims:

$1789, \mathrm{p} 35$.

62 Hunt, Lyn, Eroticism and the Body Politic, Zone Books, New York, 1993, p306 


\section{"A really amorous cunt can fuck its own father: \\ Delectable children, bring Juno off." 63}

Such language would likely alienate all but a small group of readers, given the strength of the incest taboo at the time. ${ }^{64}$ The celebration of sexuality is intended to go beyond any healthy enjoyment of the possibilities of the human body and into debauched excess. ${ }^{65}$

The purpose of this literature was not to titillate and arouse. Chantal Thomas has identified multiple descriptions of Marie Antoinette's sexual life and sexual organs that are designed to create repugnance towards sexuality rather than enjoyment; to depict Marie Antoinette as naked and sexualised is to figuratively put her in the possession of the reader. ${ }^{66}$ Thomas' argument is persuasive in intimately tying the queen's sexuality to her femaleness. Certainly there were no implications that the male participants in the queen's fictional debauchery, such as Artois, were being brought into the reader's possession. It might be argued that this was due to Artois' secondary role, but his grandfather, Louis $\mathrm{XV}$, was generally presented as taking the centre stage in a tale of sexual rapacity and immorality, so clearly it was possible for a male to be the protagonist in this genre of fiction - it simply was not desirable during the revolution. Ironically by the time of Louis XVI the narrative had been reversed - Louis XV was no longer vilified for his sexual adventurism but was instead used as a comparison that shed negative light on Louis XVI, a role he shared with Artois, who was his /behavioural successor. ${ }^{67}$ While these depictions did much to weaken Louis XVI's authority they never led to this form of public possession.

63 La Godmiche Royale.

64 Hunt connects the recurring fascination with incest in popular literature, at least before Sade, to anxieties about absent fathers, which has interesting connotations when the incest is elevated to the level of high politics and the absent father is the King. Hunt, The Family Romance of the French Revolution, pp29-31, 34-6.

65 The fact that it was necessary to stretch the limits of human sexual behaviour so far in order to do so shows that French educated society was relatively progressive.

66 Thomas, Chantal, 'The Heroine of the Crime: Marie-Antoinette in Pamphlets', trans Dena Goodman, in MarieAntoinette: Writings on the Body of a Queen, ed Dena Goodman, Routledge, New York, 2003, pp106-12.

67 Thomas in Goodman, pp103-4 
A pamphlet might be owned by one person, but it could be read by many. Even if an individual did not personally read one of the pamphlets, they would be aware of their presence, would see one being read by others, and perhaps also discussed with others. To possess Marie Antoinette individually through reading the pamphlets might be a politically significant act, but to possess Marie Antoinette collectively through participating in or observing a public discourse in which she was ritually given into the possession of the public was more significant. The subordination of the queen to the public can be seen as a democratic and liberal act aligned to the public ideals of the Revolution if not for the fact that the subordination was not civil, but sexual. This resulted in a subtle but pervasive and obviously popular gendering of the public as a whole - if the public was sexually possessing Marie Antoinette, it meant that the public was gendered as masculine.

This understanding of the public as masculine is crucial to understanding the dynamic at work. The contempt of the public eye was the righteous contempt of the upright man for a debauched woman, possessive but also distant. It did not necessarily matter that the public was made up of biological women as well as biological men - the gendering existed on a conceptual, collective plane and can be considered profound in its independence from biological reality. This shift in the gendering of the public sphere from a gender-neutral, arguably even feminine perspective based on the sexual provenance of a hereditary dynasty to one based on the masculine perspective of a morally concerned male figure, is one of the main drivers of the Revolution. The subordination and condemnation of perceived immorality that Carole Pateman identifies as forming an important part of the fraternal contract which can potentially be breached by a redefinition of sexual mores. ${ }^{68}$ Carole Pateman identified the modernist liberal state as one dominated by a fraternity, and saw the inclusion of fraternite in the slogan of the French revolutionaries as more than simple symbolism ${ }^{69}$. Obviously this fraternity is not literally one composed of actual biological brothers, but

\footnotetext{
68 Pateman, pp192-3.

69 Ibid, p78.
} 
metaphorical brothers, joined by common membership in a conceptual family of man. The removal of the patriarchal figure, usually a King but more generally oppressive government, means the brothers can cease to compete with one another and instead build a society of mutual interest based on strong, even intimate ties between men. ${ }^{70}$ This model generally corresponds closely to the reality of the Russian revolution. It is very easy to imagine the educated, idealistic liberals who formed the Provisional Government's participants and supporters as picturing themselves as brothers. In cherishing the education, national commitment and associated struggle with repression as experiences that transformed them and made them fit to lead Russia during a formative moment in her history, they created a narrative of common birth and shared life that gives rise to the imagery of brotherhood quite intuitively. ${ }^{71}$

The significance of the desire for anti-government literature shows us that the political classes were increasingly hostile to the queen, even during periods when the monarchy as a whole was not unpopular. As Thomas points out pamphlets still had a positive stance on the king up until the flight to Varennes. ${ }^{72}$ The worst the king was accused of, other than being frequently drunk and/or sexually impotent, was that he was 'too good' and innocent of sex and sexuality, in contrast with his wife's calculating immersion in a sexual world. This created an implication that the king was only guilty of being unprepared to navigate in the immoral environment in which his wife had placed him. Admittedly this image of a passive, lazy King did not correspond well with the idea of divine right monarchy (which required the King to be an exceptional being in every respect). It was capable of being reconciled with a constitutional form of government, and in the strongly anti-monarchical context of the flight to Varennes a weak defence of monarchy was better than no defence at all.

\footnotetext{
$70 \quad$ Ibid, p114.

71 Amusingly, this image fits equally well to the Bolsheviks who would so decisively overthrow the preceding revolutionary brotherhood of conservative liberals.

72 Thomas in Goodman, p106.
} 


\section{Illegitimacy and the queen:}

Until now we have treated depictions of Marie Antoinette's sexuality as primarily prurient, and not dissimilar to the discussions that might surround the sex lives of a contemporary politician. To do so is to miss an important context. A hereditary monarchy that allies the transmission of legitimacy to reproduction, regards the sexuality of the monarch and his spouse as impossible to separate from the concerns of the political classes regarding the conduct of government and the shape of state institutions. If divine right was the central basis of monarchical legitimacy, the monarch needed to be able to make a case for his own legitimacy in order to ensure a uncertain future where he could command allegiances and protect the legitimacy of his successors. But the parenthood of the putative father could, unlike that of the mother, be readily disguised or blurred. The difference between the legitimate child and the illegitimate child of a married mother was no more than the difference between one sexual partner and another, for instance the husband and the lover.

The worst-case scenario, from a divine right perspective, was that a philandering queen would admit somebody other than the monarch to her marital bed and produce a child that would be passed off as the heir to the throne. This child would be a changeling in the public crib.

Speculation about illegitimacy was an almost constant preoccupation of political literature, theatre, fiction and serious thought throughout the period of the ancien regime. When Louis XIV promoted his illegitimate children to the high nobility many commentators, including the Duc de St Simon, were outraged, even though the sovereign did so under a facade of meritocratic reward for wartime service and with the consent of the parlements. ${ }^{73}$ When, on his deathbed, Louis went even further and declared them capable of succeeding him, he was seen as violating the constitution - a violation whose identification, most significantly, marks one of the few moments when there was any consensus among the political classes as to what the constitution actually stipulated in the day-to-

\footnotetext{
73 Bluche, Francois, Louis XIV, trans Mark Greengrass, Basil Blackwell, Oxford, 1990, pp497-9.
} 
day conduct of public affairs. ${ }^{74}$ Unsurprisingly after Louis died his illegitimate children's rights were rapidly curtailed with little resistance from outside their personal circles of patronage. There seemed to be a fear that the unpleasant qualities of the illegitimate parent would somehow incarnate in the child and result in poor government - a theory altogether consistent with the divine right hypothesis even if it bore little relationship to the ideas of human virtue and the public man that had gained currency during the Enlightenment.

It is in this context that Marie Antoinette's purported affairs need to be examined. From a moral perspective the exact identity of her alleged sexual partners was irrelevant, the narrow, overtly political concern for the succession that they animated makes the identity of any false father of the dauphin potentially revealing. Names were often named. One was the Duc de Coigny, a member of her circle and veteran of the Seven Years War. ${ }^{75}$ Another was the Cardinal de Rohan, very much not a member of the queen's circle as we shall see, who is nonetheless depicted asking for consideration as 'la pere du Dauphin et peut-etre de la Dauphine?'76 Two figures, however, feature prominently in Marie Antoinette's hypothetical bedchamber; Count Axel Fersen and the Comte d'Artois.

The Comte d'Artois was Marie Antoinette's husband's younger brother. ${ }^{77} \mathrm{He}$ was generally seen as the most conventionally handsome of the three sons of Louis Le Dauphin, and also the most reactionary. ${ }^{78}$ In her biography Antonia Fraser considers that such an affair was extremely unlikely but it was certainly a popular view; every time Marie Antoinette became pregnant there was

\footnotetext{
Bluche, pp592-5.

Fraser, pp133, 216

Bord... R... Suivi d'un entretien secret entre la Reine et le Cardinal de Rohan, après son entree aux Etats-generaux, Paris, 1789, p15

77 Charles-Phillippe de Bourbon would later flee France, become prominent within the emigre community, return with the restoration and reign in France as Charles X, the last Bourbon King. His reign was generally typified by ultramontane Catholicism, a revival of medieval religious ritual and growing unrest that led to his overthrow and the final end of the Bourbon line.

78 Fraser, pp132, 259.
} 
pamphlet speculation that the father was Artois and not his elder brother. Artois as royal philanderer offers an unlikely candidate if the fear was of illegitimate corruption of the succession, given that he was second in line to the throne prior to the birth of Marie Antoinette's son. The idea of his children taking the throne would not have been very unsettling from the perspective of divine right, since there was a chance (albeit not a large one) that his children would do so anyway. ${ }^{79}$ The reason Artois kept popping up in the pamphlets was to promote the incestuous connotations that Marie Antoinette was sleeping with her husband's brother who had strong association with antirevolutionary politics, such as the purported famine plot to starve Paris and make a profit through rising grain prices ${ }^{80}$. Artois was a sufficiently hated figure by revolutionaries that the colour green was not chosen as an emblem of revolutionary France because it was also the colour of Artois' personal coat of arms.

The other figure who featured prominently in speculation about Marie Antoinette's sex life was Axel Fersen. Fersen was a child of the Francophile Swedish nobility who had served in the American Revolutionary Wars, notably as an interpreter between General Rochambeau and Washington. Although the rumours appear to be based in fact what is more relevant is the impact of the discourse. For this reason no more weight needs to be put on Fersen than on Artois simply because he was intimate with the queen (although there is little evidence that he was the father of any of her children, let alone the dauphin) ${ }^{81}$ Fersen was attractive as a topic for rumour for similar reasons to Artois. Although not as well known as Artois, to those who were aware of him he represented a picture of cosmopolitan aristocratic decadence that could have been lifted out of the pages of contemporary novellas; his romantic conquests were easily viewed as debauched orgies, and his adventurous swashbuckling was parsed as a inclination for the conspiracy and intrigue that were a permanent fear of Enlightenment ideals of good governance.

\footnotetext{
79 Artois was second in line to the throne because the middle brother, the Comte de Provence, had no children.

80 Fraser, p249

81 Fraser argues that Fersen was skilled in avoiding contraception and seemed to have an aversion to the idea of becoming a father. Fraser, pp200-1.
} 
Finally, while the connection may seem tenuous the public's fears of illegitimacy belong alongside fears that the queen had 'enervated' the dauphin through incest. In both cases the queen is seen as failing at her role, and in doing so harming the wider public interest. The idea that Marie Antoinette had interfered with her son did not appear until the very end of her life; it has no prehistory in the pamphlets in the way that her adultery does. One narrative is essentially a development of the other. Fears of the potential of adulterous queens that had been explicit in French political life since the regency of Mazarin and Anne of Austria in the seventeenth century, when the legitimacy of the then-infant Louis XIV had been questioned by the frondeurs who sought to overthrow the Cardinal and his 'mistress'.

\section{Feminine Conspiracy and the Diamond Necklace Affair:}

Fears of illegitimacy lead naturally into fears of conspiracy. The charge was not that the queen would give birth to a false dauphin and admit to her mistake, rather that she would seek to conceal the dauphin's fatherhood. Accusations of queenly conspiracy were not limited to considerations of legitimacy. In France women were barred from participation in government by virtue of their gender and any power or influence they had must, of necessity, be due to means that were, if not illegal, extra-legal. Since women had no formal power or office they could not issue instructions or pass laws, and had to attempt to persuade, bribe, blackmail and even seduce to influence outcomes. They could not present their deliberations and decisions to the public since officially their deliberations were of no interest and to actively contradict this fiction would undermine a preconception that was crucial to contemporary ideas of governance. Female power was a product of private discussions, closed rooms and personal ties, not public declarations, national theatre and professional intercourse. It belonged to the private sphere. 
In a sense this was a circular argument - because female power could not be legitimised it was illegitimate and any implication that women had a role in shaping policy, creating or maintaining an institution or promoting a candidate for office automatically made that candidate suspicious because they were tied to the world of backroom deals and particularism that female power evoked. The physical and social proximity of women to the instruments of policy-making was theoretically social, but Versailles was a place where the social and political mixed and the public and private spheres merged. It was never clear whether Louis XVI or his predecessors acted as social or political beings, and while they were required to pay no attention to the political views of their female social contemporaries, this lack of a clear divide in every other aspect of their life made it hard to have confidence that this requirement was met.

Perhaps the best illustration of underhanded dealings being connected to a feminised construction of governance is the Diamond Necklace Affair of 1785. It is hard to situate the events of the Diamond Necklace Affair in the trinity of criticisms that provides the framework for this thesis, but an attempt must be made, primarily because any discussion of the popular view of Marie Antoinette without some consideration of this event would be transparently lacking. The Affair marks the transition point between a period when Marie Antoinette, while not popular, was generally treated with a level of deference appropriate to her status in a divine right monarchy, and a period when open attacks on her became the common currency of the French political classes. ${ }^{82}$

Much as it would be preferable to pass over the actual facts of the Affair in a manner similar to the way the actual facts of Marie-Antoinette's sex life were passed over as irrelevant to the public discourse, I find myself unwilling to do so for two reasons. Firstly, the Affair was trivial on its own merits and that subsequent events could have a major effect on the institution of the monarchy without some further dynamic being at work needs to be emphasised. Secondly, even a bare

${ }_{82}$ Maza, Sarah, 'The Diamond Necklace Affair Revisited' in Goodman ed, p74. 
examination of the facts of the Affair shows that it is impossible to attach any blame to Marie Antoinette herself. Her adultery has at least a veneer of prima facie credibility when compared to her involvement, or to be more precise her lack of involvement, in the events that nonetheless became irretrievably tangled up with the wreckage of her reputation.

The main driver of the Affair was not idealism or strong emotion but a simple desire for money and power. The Cardinal de Rohan, a scion of the historically powerful Rohan family, wanted to achieve ministerial office but believed he was prevented from doing so by Marie Antoinette's dislike. A young lady in waiting of self-proclaimed illegitimate royal blood, Jeanne de Valois was able to convince him that she was in the queen's favour and began forging a two-way 'correspondence' with the queen that became increasingly warmer. Rohan eventually began lending de Valois money which she claimed was going to the queen's charitable projects.

Eventually de Valois set her eye on a valuable diamond necklace that had been designed by Paris jewellers for Madame du Barry but was turned down by Louis XV and had remained with the jewellers, who were increasingly desperate to find a buyer. de Valois was able to convince Rohan that Marie Antoinette wanted to use him as an intermediary to purchase the necklace, which was then 'picked up' by an accomplice claiming to be one of the queen's valets. In reward for his efforts de Rohan received a 'personal' statement of approval from a young actress posing as Marie Antoinette. When the jewellers demanded payment de Rohan's 'authorisation' from the queen proved to be transparently fraudulent - Marie Antoinette had supposedly signed her name 'Marie Antoinette de France' despite the fact that royalty traditionally did not use surnames. The jewellers complained to the queen, who denied knowledge and turned the matter over to the Paris police. 
To understand why this incident rebounded so strongly against Marie Antoinette, who had no knowledge of her name being used, we need to look beyond the queen's personal actions and omissions and towards the part she played in the public discourse. It could be argued that in snubbing de Rohan she had made him vulnerable to con artists offering him the lure of her favour, but such a tenuous chain of cause-and-effect is hard to sustain. It could also be argued that the secrecy of her personal affairs made it possible for criminals to impersonate members of her household. Neither explanation is satisfactory, not least because snubbing people and maintaining a secretive household were the basic currency of the upper class of the ancient regime.

The real issue was not that of the criminal fault of de Valois, but of de Rohan. It was obvious that de Valois should be charged with fraud, but could de Rohan be said to be guilty? Had he committed lese-majeste and brought the royal family into disrepute by implying that the queen might have truck with midnight rendezvous and secret handovers of stolen goods? Or was this a reasonable belief?

This was not solely a matter for legal scholars or criminal justice theorists because of France's political structure at the time. The highest court of France was the Parlement of Paris, whose members saw themselves not just as the registrars of laws and treaties and the judges of appellate justice, but as a pseudo-legislative body that represented the King of France to the people and the people of France to the King. ${ }^{83}$ Since de Rohan was a member of a prestigious noble family he had the automatic right to be tried in Parlement by his noble peers. These very same peers had recently been engaged in an ongoing debate with the monarch and his ministers about the meaning of royal authority. Due to the context of this debate, the distribution of opinions on the issue was largely determined by opinions on the rights of Parlement. In effect the trial was a second-order trial

\footnotetext{
83 Campbell, Peter Robert, 'The Paris Parlement in the 1780s' in The Origins of the French Revolution. Ed Peter
} Campbell, Palgrave MacMillan, Basingstoke, 2006, pp88-90. 
determined by a conflict outside the context of its formal points of reference. Rohan was defended by those who advocated a stronger role for Parlement, while the court party lead the charge for exile. $^{84}$

Fraser claims that the Affair captured the minds of the politically active classes because it was a good story, and it is certainly true that a mystery writer would find the humble young woman with royal blood, the midnight impersonation and the corruption in the heart of Versailles fertile ground. ${ }^{85}$ The involvement of the bizarre adventurer Count Cagliostro in the proceedings certainly did much to lend an air of story-book debauchery to the whole situation. ${ }^{86}$ But to believe that the Parisians who sought out information about the Affair were concerned only with a good story, or even a contemporary form of 'celebrity gossip', is to deny its political content. Louis XVI acted as a private person whose wife had been attacked, and as such took a very hostile approach to Rohan. ${ }^{87}$ Although many of his close advisors were enemies of Rohan and encouraged and supported him in doing so, he could have overridden them without much difficulty. Once again the King's desire to inform his actions as King by the concerns of a family man proved to be better propaganda than they were politics. Rohan was so popular that attacking him made Louis unpopular, but to bring Rohan's situation into the realm of the courts, particularly when the courts refused to confine themselves to their judicial function, was to give scope to the issue of the queen's proper role in government.

\footnotetext{
84 Just as predictably but less revealingly, members of the Parlement with personal connections to Rohan also defended him. Maza, p82

85 Fraser, p219

86 Count Cagliostro was a physician, courtier, occultist, story-teller and sexual adventurer from Sicily who claimed to have been brought up by the Knights of Malta and the Sheriff of Medina and to have been descended from the Dukes of Trebizond (and through them, from the Emperors of Byzantium), and to be a reincarnation of various figures from Egyptian history. When arrested he claimed to have been guilty of nothing but the murder of Pompey at the orders of the Pharaoh. He was aquitted after no evidence could be found connecting him to the affair - he had been an acquaintance of Rohan but had no connection to Valois. It is probable that he was arrested chiefly in order to discredit Rohan by bringing attention to his dubious association with Cagliostro.

87 Fraser, p219-20.
} 
There is nothing about the course of events that theoretically precludes them applying to a similarly unpopular male public figure. Men wore jewellery and ingratiating oneself with men was a practical way to acquire the prestige Rohan sought. Men certainly had sufficient public gravitas to make the appropriation of their good name a feasible strategy for obtaining illicit wealth. But if a male person of similar public standing - such as the Comte de Provence - had been the 'subject' of the Affair, public interest would probably have been much more muted simply because of his gender.

For the public the Affair offered a perfect, perhaps the emblematic, example of female government In its association with the clandestine, the deceptive and the venal, to say nothing of the appearance of sexually libertine charlatans like Cagliostro, the practice of organised fraud that was at the heart of the Diamond Necklace Affair strongly resembled government by influence. The actual facts of the Affair shared a theme with preconceptions about the way women exercised power. And an inconsequential connection to Marie Antoinette was promoted to a real, profound one. The pamphlet literature denouncing the queen proliferated during the Affair and did not return to its previous level after the issue was 'resolved' with the legal declaration of guilt.

Marie-Antoinette as a Bad Woman:

While the particular dynamics of ancien regime monarchy precluded viewing the sexuality of public figures as a nullity, there was a distinctly revolutionary dimension to the criticisms of Marie Antoinette's conduct of herself as a woman that, while it may have drawn on the pre-revolutionary anxieties, substantially transformed them and gave them a new power. The shift from concerns about the queen compromising the succession through adultery to similar, more radical concerns about her sexually interfering with the dauphin mirrored the transition from courtly opposition to 
revolutionary overthrow. Similarly the popular provenance of pornographic pamphlets and the trial records of the judgements of the Diamond Necklace Affair tells us that these concerns were not limited to a moralising elite - they were shared, at least on some level, with a wide section of the populace, especially within Paris. We have also seen that even when self-consciously focusing exclusively on gender concerns, it is not possible to exclude all other critiques - fears for the the status and health of the organic body of the nation intrude when the dauphin is mentioned, just as fears of secretive, personally-motivated government arise during the Diamond Necklace Affair. Gender is simultaneously a vital component of understanding the queen's public image and impossible to isolate. This is a pattern that we should expect to see substantially replicated in Russia. 


\section{CHAPTER THREE:}

\section{GENDER AND RUSSIA}

Criticisms of Alexandra Fedorovna that exploit her status as a woman to delegitimise her can readily be located, much like their parallels for Marie Antoinette. Once again, the reason for this is easy to identify - the Czarina willingly presented herself as a woman in a way she did not depict herself as a foreigner or as a tyrant. Like Marie Antoinette, she occupied a position which was specifically reserved for a woman. And similarly, it is most instructive to view her when she was perceived, not simply as a woman, but as a 'bad woman'.

Yet this chapter is no blow-by-blow replay of the pertinent points of the previous, with the protagonist's name and the setting changed. Although the the contexts the two women found themselves in were similar, they were not identical. This piece aspires to demonstrate that the same dynamics were at work in Russia in the 1900s as in France in the 1780s, but disparities must be acknowledged.

Perhaps the most important disparity is the presence of Grigori Efrimovich Rasputin in the Russian context. He is a figure who will appear throughout not only this chapter but the entire thesis. It is impossible to talk about the Czarina's public image without also talking about Rasputin. But even if it were possible to make the separation on a general level, when discussing the Czarina's gender Rasputin would inevitably creep into the picture. In the public mindset Rasputin was always near and sometimes he was portrayed literally lurking at her side. Perhaps the best example of this is the derzhit image. Distributed on a postcard in 1917, depicting Rasputin cupping the Czarina's breast with the legend 'derzhit' - literally the verb 'to hold' but also the root of the word samoderzhavie, 
or 'autocracy'. ${ }^{88}$ This is as much an image of Rasputin as it is of the Czarina, perhaps more so. But above and beyond being an image of either of them, it is an image of them as a couple - joined both physically, in the narrow sense of touching and being in proximity as well as in the broad sense of being in a sexual relationship, and politically, in that the message is less about the individual qualities or habits of either person but in the way they interact with one another. Given that gender is a category that adheres not just to an individual but to the individual's interaction with others, close attention will be given to the public perception of his relationship with Alexandra Fedorovna.

\section{Women and Backwardness:}

Any scholar who compares France and Russia is likely to find the theme of backwardness occurring again and again. Even when comparing Russia in the early $20^{\text {th }}$ century with France in the late $18^{\text {th }}$ it is hard to resist the impression that French political culture was less backward despite Russia's hundred year plus 'head start'. The term is not without moral connotations and might be seen as having little place in scholarly discourse but its use can be justified, partly because in choosing to use the term those moral and lay connotations are specifically and knowingly invoked. It is arguable whether or not Russia was actively 'backward', by which we might extrapolate a presumed meaning of being less educated, less able to enjoy the benefits of technology, and inhabited by a people of a less definably modern mindset. At the time of the revolution Russia was regarded as backward by many literate, educated Russians .

This truth is best illustrated by the centrality of the 'Lettre Philosophique' by early nineteenth century writer Pyotr Chaadaev in Russian discourse about the country's place in the world. Chaadaev's 'Lettre', an 1836 publication surveying Russia's situation and prospects as a nation, is

\footnotetext{
88 Figes, Orlando and Kolonitskii, Boris, Interpreting the Russian Revolution: The Language and Symbols of 1917,
} Yale University Press, New London, 1999, Image 1. 
unique in being not simply a remorselessly critical but almost dismissive text, which views Russia as utterly removed from the modernistic progress of humanity towards a more perfect state.

Chaadaev's narrative was taken up by both westernising Europhiles and exceptionalist conservatives alike ${ }^{89}$, but whether they saw Russia's remove from the modernist project as a tragic mistake of geography to be conquered with the same mix of intellectual application, public-spirited commitment and hopeful aspiration that one might apply to filling in a swamp or bridging a ravine, or an unalterable fact of reality that needed to be realistically admitted and even leveraged to create a unique space for Russia in the world, the fact of this remove - this backwardness - was not up for debate. There was no attempt to see Russia as 'just another country' and even this conservative decision to turn this 'backwardness' into an advantage, by emphasising the humility (and associated religiosity), authenticity and uniqueness of the state of being Russian did nothing to negate the assumptions that led to this state being identified as one of 'backwardness'. Conservatives might decry Western Europe's over-sexualisation and contrast it unfavourably with Russia's meekness and chastity, but they would not deny that the former was modern - they simply saw it as a reason to reject modernity and embrace the past. ${ }^{90}$ As Catriona Kelly put it: "colonizing Mars by spacecraft could seem as likely a possibility as lowering infant mortality, providing rural areas with sanitation or paving the streets of provincial towns." 91 Chaadaev is both the progenitor and best illustration of the phenomenon of the idea of Russian backwardness. Although Chaadaev wrote long before the period we are studying his work remained highly relevant; it was firmly censored until 1914, when a small selection appeared just prior to the outbreak of the war. ${ }^{92}$ This allows us to conclude that whatever the truth of Russia's backwardness, there was certainly a perception of backwardness among the policy-making elites who were best placed to 'do something' about it..

\footnotetext{
89 Peterson, Dale E, 'Civilizing the Race: Chaadaev and the paradox of Eurocentric Nationalism' in Russian Review, October 1997, p551. Chaadaev would later go on to partly renounce his views in an apologetic entitled 'Lettre d'un Fou' but this did little to lessen their currency.

90 Shlapentokh, Dmitry, The French Revolution in Russian Intellectual Life, 1865-1905, Transaction Publishers, New Brunswick, 2009, pp15-9.

91 Kelly, Catriona, Utopias, Penguin, New York, 1999, pxxiv.

92 Peterson, p556.
} 
This perceived backwardness might lead us to feel that the situation of women in Russia would be a grim one. While the transition from pre-modernity to modernity is often more retrograde than it seems, it is generally accepted that the improvements it brings for women are marked. As such one would expect Russia on the eve of the revolution to be a milieu where women were generally subordinate to men and where the benefits of gender equality in even its most basic form were not acknowledged. One would further expect the revolution to swiftly correct this. To an extent this is born out. The plight of the average woman in Russia, particularly the average peasant woman, was widely noted. Dostoevsky's novels dwelt at great length on the suffering of prostitutes, widowed mothers and women in abusive marriages. Gorky publicised his failed attempt to rescue a peasant woman from rape by village elders. Alexander Izgoev lamented the inability of Russian mothers to bring up their children with a healthy set of moral values, and the resulting sexual exploitation of servant girls and prostitutes at the hands of elite youths. ${ }^{93}$ It seems that this broad cross section of intellectuals - Dostoevsky was a conservative, Gorky a revolutionary socialist and Izgoev a liberal - could all agree on one thing, that life as a woman in Russia was hard.

This perception of female hardship was not limited to the impreciations of intellectuals. Although the Provisional Government of Lvov and Kerensky did not endure long enough to set up a clear policy legacy, on the level of rhetoric there were signs of strong commitment to gender equality. Women's suffrage was a founding policy of the Constitutional Democrats, a party who would dominate the Provisional Government. ${ }^{94}$ This commitment was broadly paralleled among the antiCzarist parties and was achieved under the Provisional Government, which raised women's legal position to one that merited favourable comparison with the situation in France, Britain and the

93 Izgoev, Aleksandr, 'On Educated Youth: Notes of its Life and Sentiments' in Landmarks: A Collection of Essays on the Russian Intelligentsia, Boris Shragin and Albert Todd eds, trans Marian Schwartz, Karz Howard, New York, 1977, pp89, 91

94 The policy faced strong opposition from within the party and passed only narrowly, but was never abandoned. Stockdale, Melissa Kirsche, Paul Miliukoff and the quest for a Liberal Russia, Cornell University Press, Ithaca, 1996, pp144-5. 
United States. ${ }^{95}$ A parallel display of commitment to improving the lot of women was the appearance of the 'working men and working women' formula, which began to appear in official resolutions in 1917, partly displacing the prior preferred rotes of 'workers' and 'working people'. ${ }^{96}$

But the picture of oppression ended by revolution is not entirely vindicated by the facts. If Russia truly was a backward, anti-modern society and thus one hostile to women, one would expect any advocacy for women's rights to have the character of a beleageured resistance, perhaps dogged but not vital. This was not the case. Although Russian feminists were certainly aware of the setbacks and obstacles they faced, the level of activism in the foundation of feminist political clubs, parties and congresses compares quite favourably to the obvious European referents. The most obvious sign of this was the successful convocation in December 1908 of the All-Russian Congress of Women. Perhaps unsurprisingly, the chief weakness of the various feminist or proto-feminist movements, other than their periodic persecution by the authorities, was in difficulty expanding from their almost exclusively urban-professional base to the peasant women of the countryside. ${ }^{97}$ But despite this there were grounds for hope for those concerned with the status of women in Russia well before the Provisional Government came to power. Institutions and groups were founded, and while they were often short-lived, they were always replaced; the constant foundation, collapse into moribundity and re-foundation of various feminist groups can be seen as a sign of vitality and adaptation as much as one of confusion and ineffectiveness.

\section{The Czarina at War}

From 1914 the Russian Empire was at war. Although Marie Antoinette was also Queen of France during a war, the situation had several notable differences which make comparison difficult. Firstly,

\footnotetext{
95 Read, Christopher, From Tsar to Soviets: The Russian people and their Revolution, 1917-21, UCL Press, London, 1996, p84.

96 Read, p86.

97 Edmondson, pp83-4.
} 
Alexandra sat on the throne during three years of war, while Marie Antoinette was Queen for a much briefer period of conflict - France's declaration of war on Austria on the $20^{\text {th }}$ of April 1791 preceded her formal removal from the throne on $21^{\text {st }}$ September by almost exactly five months. Secondly, and more importantly, there was little expectation among partisans of the war that Marie Antoinette would support it. The war was being waged against a coalition in which her brother, Hapsburg Emperor Leopold II, played the major role, and the casus belli was inextricably combined with the course of the revolution that had deprived her of her legitimacy and, eventually, her life. Conversely, Alexandra Fedorovna was Queen for three years of war, a war which the monarchy was explicitly committed to and associated with from its outset. She had to find a way to demonstrate her commitment, on a personal level, to the war. Her attempts to do so and the criticisms of those who saw these attempts as inappropriate revealed much about contemporary gender narratives.

A discussion of Alexandra's role as a wartime leader might seem to belong to a discussion of her position vis-a-vis the Russian national idea. This is certainly true, and an attempt to present such a discussion will be made in chapter seven. However it is worth investigating exactly how she undertook to make this commitment. A parallel is sought not in her actions as a public person, but as an ostensibly private one (although presenting her private persona to the public, for public goals). In the same way that Nicholas, in donning the clothing of a (comparatively) humble colonel, did his best to stress his position as simply another Russian in emphasising his dedication to the war effort, his wife similarly sought a way to show herself to be part of the national narrative from a position of parity with her subjects. In the same way Nicholas was an ordinary man, she sought to be an ordinary woman - and to make an example of herself to other Russian women.

The parallel for Alexandra to Nicholas' military service was nursing. During the nineteenth century the expansion of military medical services and the prominence of such figures as Florence 
Nightingale led to a greater prominence of military nurses in the public eye. Indeed, although Nightingale is well known in the English speaking world there is a case to be made that Russia was the true pioneer in this sense; while Florence Nightingale was tending to British wounded in Scutari, on the other side of the Black Sea from the Crimean battlefield, Dr Nicholai Pirogov, a field surgeon, organised and accompanied a group of army nurses known as the Sisters of Mercy of the Exaltation of the Cross to the front lines in the Crimea. In a sense the image of the nurse offered the ideal image of the war-committed woman. She made a direct contribution to battlefield success without actually being present on the battlefield. She incarnated the stereotypical image of the virtuous woman - nurturing, caring and chaste. She was able to negate the violence and horror of industrial warfare without directly participating in it. This idea of women as incapable of violence and thus needing to approach indirectly their duty to contribute to the state's achievement of its goals through violence (e.g. war) is perhaps nowhere better illustrated than it is in the case of Maria Bochkareva. A peasant woman from Novgorod, Bochkareva received the Czar's personal permission to enlist in a military unit and became a celebrated soldier, later charged with organising an all-female military unit. However it is notable that even after she had participated in multiple battles the story that was most often used to depict her devotion and bravery was that of her facility in rescuing wounded soldiers, not doing any wounding herself. ${ }^{98}$ Even in uniform and armed, Bochkareva was essentially still depicted as a caregiver and protector.

The glorification of nurses was not limited to Russia; it was part of a wider modern phenomenon. At the time nursing was seen as a uniquely female profession, so any statement made regarding nurses can be seen as a statement regarding women. An article in the American Journal of Nursing described missionary nurses as 'heroic' and praised the wider ability of nurses to 'combat' 'immoral tendencies' and to promote 'self-control' and 'self-discipline' in men - virtues which, while phrased

98 Alpern Engel, Barbara, Women in Russia: 1700-2000, Cambridge University Press, Cambridge, 2004, p129 
in a peacetime context, have obvious implications should a society find itself in a war. ${ }^{99}$ In France the Red Cross used the narrative of civilian inaction as responsible for defeat in the Franco-Prussian war, and the redeeming potential of civilian engagement in a future war, as a powerful and successful recruiting tool. ${ }^{100}$

The practice of nursing as an expression of wartime duty was hardly unique to Alexandra Fedorovna. Grand Duchess Maria Pavlovna, a second cousin of the Czar, volunteered to serve as a nurse. ${ }^{101}$ Another Grand Duchess, Olga Alexandrovna, the Czar's younger sister, served as a nurse in the town of Rovno. Alexandra's older sister Elizabeth Fedorovna, who had married the Czar's uncle Sergei, pioneered this path before the war, retreating into a monastery after being widowed by an assassin, and acted as a nurse towards the poor of Moscow. Indeed, many Russian women volunteered for medical service throughout the war, but it can be safely assumed, although there is little concrete statistical information, that they were mostly of the middle and upper classes. ${ }^{102}$ Pirogov's Sisters were all of the noble orders, and there is little reason to suspect that their successors were not similarly drawn from the highest rank of society. The cultural, educational and economic obstacles that would present themselves to a peasant woman who wished to make herself available for voluntary nursing service would certainly be formidable indeed.

The act of nursing was seen as an act of self-abasement by the nurse. This was consistent with Russian feminist journal Zhenskoe Deloe's exhortation to its readers, mostly middle class professional women, that they must undertake a 'holy sacrifice'. ${ }^{103}$ One newspaper emphasised the extremely hard work done by Grand Duchess Olga, exclaiming that 'for The Princess, neither day

\footnotetext{
99 Stanley, Elva Mills, 'Nursing and Citizenship' in The American Journal of Nursing, Vol 1, No 16, Oct 1915, pp224.

100 Chrastil, Rachel, 'The French Red Cross, War Readiness, and Civil Society', French Historical Studies, Vol 31, No 3, Summer 2008, pp457-9.

101 Stites, Richard, The Women's Liberation Movement in Russia: Feminism, Nihilism and Bolshevism 1860-1930, Princeton University Press, Princeton, 1978, p279.

102 Edmondson, p162.

103 Alpern Engel, Women in Russia, p128.
} 
nor night exists'. ${ }^{104}$ The sacrifice was not necessarily personal. Both Tsarskoye Seloe and the Winter Palace were transformed into parts of the Russian military medical network, with the former being transformed into a hospital and the latter into a workshop making bandages. ${ }^{105}$ This is another reason that nursing was chiefly concentrated among the upper ranks of society; it was a response to an implicit criticism that the suffering being felt at a societal level was not shared by the royal family. In trading in their robes of state or expensive casual clothing for the plain white vestments of nurses and in opening up their previously private, luxurious palaces to ordinary soldiers, the Czarina and her family were indulging in something that was not entirely removed from a deliberate act of self-flagellation. It also had parallels to dynastic ideas of the Queen as mother of the state.

Alexandra Fedorovna's discernment of the criticisms facing her and her attempts to ameliorate them through nursing compares favourably to Marie Antoinette, whose only response to the growth of opposition was courtly intrigue. But this discernment was not effective. By the end of the war a strong association of nurses with prostitutes had appeared, and the sexualised jokes made by peasants and soldiers began to be applied to the Czarina and her daughters. ${ }^{106}$ By placing themself in the public eye, Alexandra Fedorovna had offered the public a way to figuriatively sexually possess her, thus gendering itself, in a fashion quite similar to Marie Antoinette's possession via the pamphlets.

An illustration of the difficulty the Czarina faced in her attempt to present herself as a wartime leader can be found in an unlikely place - a study of the brief tenure of Alexander Kerensky as Russia's leader. Kerensky is something of a paradox in that his brief period in office offers a study in both extremes of popularity, with little in the middle; he went from object of a veritable personality cult to a despised national traitor within the space of roughly six months. Having

$104 \quad$ Ibid, p129.

105 Ibid, pp128-9.

106 Alpern Engel, Women in Russia, p129. 
established early in his career a position of informal dominance within the Lvov Ministry despite holding only the relatively modest office of Ministry of Justice, he was able to exploit his status as the institutional conduit between the Soviets and the Provisional Government to become Minister of War, Vice Premier and finally Premier after Lvov's resignation. Although Kerensky worked hard at cultivating a personal following among the lower class workers and soldiers who had actually made the revolution, and was not unsuccessful in doing so - he certainly commanded a more substantial popular following than Lvov, Guchkov, Miliukov and Nekrasov put together - ultimately his unpopularity rose due to his continued commitment to the allied war effort. Both elite and popular supporters turned against Kerensky, and many of the criticisms that he, like the Czar, began to find accreting to him were phrased in the form of attacks on his masculinity.

Zinaida Gippius, an erstwhile ally of Kerensky's, named him as an 'old woman', a 'chatterbox' and 'hysterical' in a polemic that marked her turning against him. ${ }^{107}$ Richard Pipes, writing well after the events but generally from a perspective that is sympathetic to Kerensky's conservative foes, speaks disapprovingly of a 'Kerensky plot' and uses language that, while not explicitly feminised, carries definite pro-masculinist weight, such as when he derides Kerensky during the Kornilov affair for not being 'firm' and for being 'unable to think straight' when he was 'exhausted'. ${ }^{108}$ But the most complete demonstration of this phenomenon is one where no drawing of connections between the feminisation of Kerensky and the Czarina is required of the reader. During the final weeks of government the connection was made explicit by a popular joke that circulated among those interested in politics; 'Q: What is the difference between Russia today and at the end of last year? A: Then we had Alexandra Fedorovna, but now we have Alexander Fedorovich" ${ }^{109}$.

\footnotetext{
107 Figes \& Kolonitskii, p94.

108 Pipes, pp133, 135.

109 Figes \& Kolonitskii, p93.
} 


\section{Fears of female intimacy in the revolutionary fraternity:}

We have seen in chapter two the manner in which revolutionary fraterny as identified by Pateman is a necessary prerequisite for modernist revolutions. One might easily conclude that this deep valuing of homosocial intimacy among men would lead the liberals to approve, if only at an abstract distance, of similar homosocial intimacy among women. This was not, however, the case. In the same way that a woman intruding onto the public arena is seen as non-feminine and unnatural, as Marie Antoinette would have discovered had she been more alert to the gender dynamics acting on her, a woman establishing intimate, political friendships with other women is similarly challenging. It would be going too far to say that all friendship between women was stigmatised by the Russian revolutionaries. Certainly non-political friendship was uncontentious. Presumably figures like Struve, Miliukov and Kerensky were content to allow their wives to cultivate friendships with other women. However when these friendships became political they became objects of suspicion. In general the thoroughgoing exclusion of women from all positions where they could enjoy political relationships of any kind necessarily precluded political friendships as much as it did political sexual relations. However the status of Alexandra Fedorovna as the most prominent and 'first' woman of Russia meant that anything she did could be identified as political. This would lead one to expect her friendships with other women to have been strongly stigmatised by revolutionaries, and this was the case.

The lightning rod for these criticisms of the Czarina was a woman named Anna Vyrubova. Vyrubova came from a distinguished family which had enjoyed Imperial favour for several generations, but she established a particularly close personal relationship with Alexandra after a courtesy visit by the Empress to her bed during a period of illness. Eventually Anna moved into a cottage in the grounds of Tsarskoe Selo and enjoyed regular private audiences with the Imperial 
couple. It was through connections with Anna that Rasputin was first introduced to the royal family. In his biography Massie presents Anna as uninterested in politics and enjoying a purely personal relationship with the Czarina - a friendship between two individuals, one of whom happened to be a political figure. ${ }^{110}$ He acknowleged Vyrubova's introduction of Rasputin to the Czarina but seems to feel this was essentially a coincidence and a curiosity. Others disagreed. Pares described Anna as 'hysterical' and 'entirely under the influence of Rasputin', and disdained her 'confused mind' as theorising a pseudo-revolutionary conspiracy between some of the Grand Dukes, Duma President Rodzianko and the socialists. ${ }^{111}$ Kerensky, in a self-justificatory piece written in 1930, claimed that after Rasputin's death Vyrubova became the "interpreter of the posthumous will of the 'holy father'", effectively conflating everything obnoxious about Rasputin's presence at the elbow of the royal family with her own. ${ }^{112}$ Varnava, the Bishop of Tobolsk, imputed to her the ability to influence the Czar on religious matters when he wrote to her asking for her to assist him in obtaining the canonisation of Metropolitan Ioann Maksimovich, an $18^{\text {th }}$ century bishop of his see. ${ }^{113}$

The charge that Vyrubova was seeking to manipulate the Czarina in the name of some form of agenda, be it one inspired by treason with Russia's wartime enemies, internal conspiracy to impose a tyrannical state, or simply to personally enrich herself, was one that tells us little about Vyrubova. But it tells us much about Alexandra and a great deal about the context in which these two women, along with their accusers, operated. It is extremely noteworthy that when she was brought before the Revolutionary Government's organs of justice Vyrubova sought to display her innocence by submitting to a physical examination proving her virginity. What is potentially even more noteworthy is that the court accepted her offer and admitted the evidence. This was an astounding

\footnotetext{
110 Massie, Robert K, Nicholas and Alexandra, Ballantine Books, New York, 1967, pp156-60.

111 Pares, Bernard, 'Sir George Buchanan in Russia' in Slavonic Review, Vol 3, No 25, Mar 1925, pp583-4.

112 Kerensky, Alexander, 'Why the Russian Monarchy fell' in The Slavonic and East European Review, Vol 8, No 24, Mar 1930, p509.

113 Freeze, Gregory, 'Subversive Piety: Religion and Political Crisis in Late Imperial Russia', The Journal of Modern History, Vol 68, No 2, June 1996, p343.
} 
compromise of the court's liberal credentials. Under any even vaguely liberal reading of the issue, Vyrubova's virginity, as an adult woman, was nobody's business but her own, and had absolutely no bearing on the issues she was ostensibly being tried for. She was perfectly capable of committing 'treason' as a virgin, and had she lost her virginity it would have proved nothing - she was a widow, and thus had ample excuse for having had sex. The admission of her virginity into the formal records of the extraordinary court - not simply a regular court of law, it must be remembered, but one charged with codifying the unique circumstances of Russia's transition to a democratic state must be seen as extremely revealing. The revolutionary government clearly envisaged its role as enforcing a particular idea of female sexuality and what was and was not an appropriate form of intimacy between women.

\section{The Czarina and pornography:}

In chapter two the political pornography depicting Marie Antoinette was identified as a way to gender the public body by producing an image of the Queen clearly intended for a disdainful masculine gaze, thus allowing even female members of the public to masculinise themselves while playing a public role, namely analysing the Queen's role with regard to the public good. If this dynamic were rooted in something more profound than the particular circumstances of France, as was argued, we would expect to see either a similar appearance of political pornography in Russia concerning Alexandra Fedorovna and her peers, or a good reason explaining its non-appearance.

Sadly political pornography in Russia has not been the subject of as extensive a study as its French counterpart. Orlando Figes points out that such pornography certainly existed, although ironically it was less sexually explicit than that published during the French revolution. ${ }^{114}$ Perhaps the best example of this pornography is the already-discussed 'derzhit' image. Although not especially

\footnotetext{
114 Figes \& Kolonitskii, p10.
} 
sexually explicit - in the modern context it would barely even qualify as pornography - it did succeed in depicting the Czarina in a pose that was sexualised, and compromising in its sexuality. If we take this piece to be representative it is tempting to conclude that the relatively inexplicit nature of the material does not mean that the dynamics at work in France were not also present in Russia. This is particularly true if one considers the fact that there is a long tradition of relative discomfort with nudity in Russian visual art; not until the $18^{\text {th }}$ century did Russian painters begin depicting the naked form routinely, and even medieval religious art shows a noted aversion to nudity, let alone sexuality. ${ }^{115}$ It is further clear that what this political pornography lacked in hardcore material it did not lack in volume. In the post February revolution era, when the floodgates of censorship had been opened, pamphlets routinely sold between 25,000 and 50,000 copies each. ${ }^{116}$

Moreover Russians had access to whole new mediums, of which the most notable was cinema. The appetite for films based on the 'secret lives' of the royal family was prodigious. They were often made in two to three days, and clearly, like all other political pornography, served as much to gratify as to promote a particular view on the way power worked in Russia. ${ }^{117}$ But as with their postcard and pamphlet producing competitors, the fact that these cinematic entrepreneurs, clearly working to a business plan that emphasised doing the minimum possible to meet a surging demand - hence the ridiculously short production cycle - chose to complicate what could otherwise be a fairly simplistic, mechanical depiction of human sex with a story, let alone a story ripped from the headlines of the day. It is notable that the laws surrounding depiction of the royal family had previously been very strict, whereas in the post-February political and legal environment the narrative that the pornographers were promoting effectively had official endorsement from the government of the day. It is possible that the previous sacralisation of the monarchy, by rendering it

115 Kon, Igor, 'Sexuality and Culture' in Sex and Russian Society, Eds Igor Kon and James Riordan, Indiana University Press, Bloomington, 1993, pp16-18.

116 Figes \& Kolonitskii, p11.

117 Figes \& Kolonitskii, p12. 
beyond the reach of sexuality in a manner even more complete than that of society as a whole, made its exposure even more appealing. The cinema-goers who flocked to the cinemas to view crude parodies of the Czarina, various ministers and courtiers, and of course Rasputin cavorting in badly done celluloid were the ideological cousins of the peasants gawping at the interior of the previously closed manorial house. This can only have served to reinforce and contextualise the gendering effect of the act of looking - the viewers of these numerous and largely nameless films were not only made to view the Czarina as a sexualised woman, thus implicitly putting themselves in the position of a man, they were valorised in doing so by implying that her sexual nature had previously, and of course unjustly, been denied to them. It is more than possible, in other words, that in adding a counter-tyrannical dimension to this gendering of the public gaze, the pornographers of 1917 made an even more profound contribution to the creation of a masculine, homosocial, public-based image of the state to displace the supposedly feminine, homosexual, private image that was used to describe the ancien regime than did their counterparts in 1792 .

\section{Rasputin and the Czarina:}

The transition from discussions of pornography to discussions of Rasputin is a natural one. It is in the pornographic context that the image of Rasputin as sexual confidant of the Czarina rises over and over again. Generally these depictions of the Czarina and Rasputin as a sexual duad served to undermine the authority of the Czar. The discussion of the ideological underpinnings of absolutism in chapter seven might be seen to call this into question, as here Czarism was identified as a product of Russian particularism, as an attempt to utilise institutions arising from Russia's unique nature as an extra-European state. This is true, but these justifications did not extend to the authority of any particular Czar, as was seen by the various conservative absolutists who simultaneously defended Nicholas' right to reign absolutely while bemoaning his inability to provide the right quality of 
absolute leadership. It might have been sufficient to demand technical allegiance to the Czar as a person based on his institutional position, as absolutism closely aligned the personal with the institutional. But in the same way that few people will obey a law simply because it is a law, but instead need a story, however questionable, about the necessity of the law, all but the most icily phlegmatic absolutists needed a reason to believe that vesting political authority in the person of the Czar was not simply legally and formally necessary but actually useful and beneficial - that the Czar was somebody in whose person one would want to vest authority. These justifications justifications for the Czar, as opposed to for Czarism - depended more on the Czar's selfpresentation than on any absolutist theory.

In the case of Nicholas, the Czar was seen as a religiously moral man - meek, humble, but selfconfident and morally correct - and as a father, exercising a paternal authority over his subjects. In traditional Russian peasant marriages the subordination of the children was not just equivalent to the subordination of the wife, it was effectively the same relationship; a single, holistic father-right was exercised over the entire household, including potentially over their son's wives. ${ }^{118}$ It was this sense of fathership that Nicholas was attempting to access as a source of legitimacy when he chose to emphasise his status as a father. The only images of Nicholas available to the public that did not depict him performing his duties as head of state (or his subordinate military or religious duties) were those of him as a father and husband. Admittedly these images were usually closer to the mold of a bourgeois father taking tea and playing games on a lawn, and were possibly more recognisable in Paris and London than in Saratov or Ufa. But even if the nuance of the message of the 'father Czar' was not perfectly pitched to correspond to the institution of peasant patriarchy, the basic comparison remained one to an institution where the authority of the husband and the authority of the male parent were tightly linked.

118 Alpern Engel, Barbara, Between the Fields \& the City: Women, Work \& Family in Russia, 1861-1914, Cambridge University Press, New York, 1994, pp12-13. 
This meant that to devalue the Czar as a husband was to devalue him as a parent, and subsequently as a figure of political power. This narrative became particularly strong when the Czar departed for the frontline. The sexual lives of the peasants who found themselves in Nicholas' armies during the war remain outside the realm of English language scholarship. However, studies have been made of peasant men separated from their families for involuntary reasons prior to the war (chiefly economic migration to factory towns) showing that female infidelity in the face of male absence was often seen by the wider community as understandable, if not acceptable, particularly when the absence was seen as separating the husband from the community. ${ }^{119}$ Given this qualified acceptance of adultery, it seems highly plausible to speculate that, just as the paternal political authority of the father Czar was understood by Russian peasants through their own experience of the paternal authority of their own fathers, the prospect of that authority being compromised by adultery was similarly experienced through the men's own anxieties regarding the women they had left behind, which were bound to be significant. Russian peasant society seemed to expect women to be reasonably sexually proactive. A man was expected to have sex with his wife not simply in order to have children but to address a legitimate need on her part. ${ }^{120}$ As such a man who did not have sex with his wife was not only personally deficient but in a way failing to fulfil the duty necessary for marriage to survive - a necessity which assumed greater significance than the personal in both the peasant community and in the chancery of Tsarskoe Selo (albeit for very different reasons). The idea that a woman's behaviour could shame a man's was widespread in Russia at the time, and was manifest in venues as unlikely as military recruitment, where the main explained purpose behind the recruitment of all-female military units under the Provisional Government was in the hope of shaming male soldiers who would not want to be seen as fighting less bravely than women. ${ }^{121}$

This assumes that the Czar was opposed to the idea of an affair between his wife and Rasputin and

\footnotetext{
119 Alpern Engel, Between the Fields and the City, pp55-6, 58.

120 Alpern Engel, Between the Fields and the City, p16.

121 Alpern Engel, Women in Russia, p135.
} 
allowed it to take place through inattentiveness. The other possibility, one that was equally compromising to the Czar's parental authority and also to his moral authority, is that he was aware of the affair but allowed it to happen knowingly. In a sense this narrative belongs with the other theories, discussed in chapter seven, relating to the idea that the Czar was giving Rasputin inappropriate powers and privileges; the idea of the Czar somehow granting Rasputin the right to bed his wife can be seen as belonging alongside other charges that he had given Rasputin the right to veto ministerial appointments, or Rodzianko's assertion that Rasputin had been appointed to the (non-existent) office of 'Imperial Lamplighter'.

But of course the right to have sex with, let alone impregnate, the Czar's consort could not be understood simply as another prerogative to be granted to a worthy, trusted subordinate. Although Russian peasant culture, as we have seen, had a reasonably lenient approach to the sanctity of marriage, born as much out of agrarian pragmatism as any ideological belief in female purity or the need to formalise romantic relationships by registration with the state, the marriage of the Czar was another affair entirely. For the Czar to have unknowingly allowed another man to sleep with his wife would have been to undermine his familial claim to authority but for him to have knowingly allowed it, even encouraged it or stipulated it, would have been to undermine his moral authority. Relaxation about adultery in the face of absent husbands has to be understood in the context of often brutal punishments for adulterous behaviour when there was not some form of mitigating factor; punishments that often actively involved the entire community. ${ }^{122}$ And by the same token that the husband's unwilling inability to address his wife's sexual needs was seen as a partial excuse, a deliberate inability, let alone a cold-blooded arrangement to allow another man to fulfil his role, would be seen as the opposite. Adultery committed due to longing or passion was mitigated, but adultery conceived as a cold-blooded bargain was aggravated.

122 Like many other peasant societies, Russian peasants had elaborate rituals concerning the public shaming and punishment of adulterous women. Alpern Engel, Between the Fields \& the City, p24 
It is for this reason, that both the image of Nicholas as unwitting cuckold and scheming dispenser of his wife's sexuality compromised his authority equally and in essentially the same way, by preventing him from exercising the moral-paternal authority he claimed, that little effort was ever given to explain the precise circumstances that led to the Czarina's supposed infidelity with Rasputin. In both cases, the Czar was a fraud, claiming an authority on the basis of qualities he did not have. This explanation clearly overlapped and reinforced that which claimed that Rasputin's sexual relations with the Czarina gave him some level of power over her, and through her over Nicholas and the government as a whole, but in order to fully understand the gender implications of the supposed relationship it needs to be considered in isolation. The question that must be asked is, 'had Rasputin's affair with the Czarina been seen as purely sensual and unconnected to the activity of government, would it have been objectionable?' The answer is clearly that it would have been. Of course the waters are muddied by the fact that in a sense the critics of Czarism accepted the logic which equated fatherhood with governance; in the same way that the Czar and his ideologues attempted to explain the manner in which he would be an effective administrator by portraying him as an effectual father rather than in the language of administration, efficiency and policy - a language that they, as opponents of the enlightenment project, were uncomfortable with if not incapable of deploying - so their opponents explained the Czar's incapacity in government by portraying him as a poor father, whereas the narrative more fundamentally destructive to the ideological foundations of Czarism would have been one that rejected the equivalence altogether and rejected any connection between the act of exercising paternal authority over a household and the act of governing a state. Whether anti-Czarists refused to make this leap out of pragmatism, genuine belief or scepticism of the ability of the peasants to understand it is an interesting one but ultimately unimportant. The debate as to whether the Czar was a good ruler could effectively be conducted on the grounds of whether or not he was a good father, and such an argument, particularly in the face of the Czar's extreme (and somewhat paradoxical) concern for his personal 
privacy, had to concern itself with speculation and the often laboured interpretation of quite minimal information, such as the interactions in public of Rasputin and the Czarina.

The Czarina in the eyes of the law:

Unlike Marie Antoinette, the Czarina was never put on trial. The Provisional Government had no real stomach for resolving the issue of what to do with the personages of the royal family; Kerensky's decision to dispatch them to Siberia was more dictated by a desire to defer the issue than out of any attempt to punish them. The Bolsheviks approached the problem from entirely the opposite direction, although legalistically they ironically reached the same conclusion - there was not even a show trial for the Czarina and her family, who were executed under the rubric of wartime expediency. As such she was never given an opportunity to defend herself, nor were historians given the chance to hear an official version of the new state's explanation for its approach to her and her family. Instead one must rely on semi-official or off-the-cuff comments by various political actors of the time, such as Miliukov's or Byzdan's as recorded in Chapter Seven. Similarly, before the revolution the Czarina's personal affairs never entered the realm of legal contestation, even by implication. It is highly doubtful that a member of the Imperial family could ever have been successfully brought to trial, when even the Czar's cousins, such as Grand Duke Dmitri, could evade being brought to trial for murder by going into voluntary exile. Nonetheless, there was no Russian equivalent of the Diamond Necklace Affair, much less the final trial and sentencing of Marie Antoinette, for the Czarina, who was spared the necessity to plead to a court for her life, if not the actual result of a death sentence. The closest the Czarina ever came to being involved in a court case was when the officer Miesadov was executed for supposedly corresponding with the enemy. Miesadov was a protege of War Minister Sukhulminov, who was in turn close to Rasputin, who owed his influence over ministerial appointments to the Czarina. It was possible to see 
Miesadov's supposed treason as reflecting poorly on the Czarina's role but the connection was a distant one, particularly compared to Marie Antoinette's presence at the narrative, if not formally legal, heart of the Diamond Necklace Affair, which quickly became a debate about her role far more than it was about the actual facts of the case.

However it is not difficult to reconstruct, from the actions and statements of those who would have been in positions to initiate and manage the trial of the Czarina had she ever been brought to trial, roughly how such a trial would have proceded. One does not have to reach far to establish parallels between the Diamond Necklace Affair and this trial-in-theory. As has already been noted, the brief of the prosecution in the Affair was to create and propagate an image of illegitimacy revolving around the presence of actually feminine and politically feminised individuals. The inclusion of the bizarre, gothic and retrograde in such a trial would have been as crucial in Russia as it was in France, as both were societies where the elite thirsted for modernity and relied on baroque stereotypes of its primitive alternative to form their collective identity. Where the Parlements had to drag the figure of the Count of Cagliostro into the formal proceedings of the trial in order to lend the proceedings the air of the bizarre and even supernatural by association, there would have been no need to stretch their net so far and so thinly to find a comparable figure. Rasputin provided everything that could have been needed, and more. It may be for this reason that otherwise secular, liberal thinkers such as Rodzianko and Yusupov were quite willing to describe Rasputin as being in possession of actual, supernatural powers to hypnotise and control their minds; in proudly describing their own resilience, through willpower and adherence to their vision, they were offering a constrained but exemplary metaphor for the ability of Russians as a whole, through their steadfast adherence to a goal and willingness to cultivate the right mental attitudes to reach it, to achieve it in the face of the ill-understood but unmistakeably real retrograde forces of primitivism and antirationality. Rasputin, the supreme self-promoter, may not have realised that he had lost control of 
his own image, that the image of authentic Russian-ness he worked so assiduously to cultivate and propagate could quite easily be flipped around, and what was authentic became chthonic and sinister. His ancient and storied practices became archaic and impenetrable habits; his natural and open sensuality became untamed and visceral satyrism; his privacy became secrecy; his modesty concealment; and his moral homilies fanaticism. He was equally able to play the role of the supernatural tempter in folkish pseudo-moral political narratives as he was the resolute and modest hero.

\section{Russia and Women:}

The picture drawn above is one of a Russia suspicious of female leadership, united around a vision of the transition to modernity that valorised stereotypically male traits and rejected stereotypically female traits - indeed, which tended to interpret generically undesirable and non-stereotypically gendered traits in female terms. It should come as no surprise that the only public woman active in this system should attract significant criticism for the simple fact of being a public woman. It might be speculated that it would be entertaining to wonder whether, given more astute political management, different external factors (for instance, an absence of Rasputin) or simply better luck, Alexandra Fedorovna might have escaped some or even all of this opprobrium. But doing so would add little to this thesis, not least because it could persuasively be argued that, rather than propelling himself onto the scene by his own drives and motives, Rasputin appeared largely because there was room for him - room for an authentic representative of Russian-ness in a court seeking to bypass elite society and connect with the peasantry but unable to distinguish between a genuine and proxysymbolic connection, and room in the enemies of the monarchy's rhetorical arsenal for a tempterfigure to point to as the poison for which they were the antidote. What may instead provide a more interesting avenue for investigation is to see whether this refusal to countenance female leadership 
extended to those who were not female. So far we have focused on the Czarina and on Vyrubova who, while not a leader, often had policy-making powers attributed to her, and seen that they were indeed politically stigmatised for being women. But what is really needed in order to drive the point home is the existence of a male figure who had feminine traits ascribed to him. Rasputin was rarely presented as feminine, and the Czar was at best insufficiently masculine rather than actually feminine. But the criticism of Kerensky as feminine once the Czarina had left the scene clearly shows that to be female in the public eye was not acceptable. 


\section{CHAPTER FOUR:}

\section{FRANCE AND NATIONALISM}

The French revolution was a nationalist revolution. The French revolutionaries saw in the mass of the French people a legitimacy that overruled feudal claims to authority. But unlike the nationalist revolutionaries who would follow their example, in Italy, in India or in Vietnam, French nationalists faced no oppressive foreign power, no alien polity denying the right to an ethnically distinct state, no penalties to the use of French or the practice of French culture. And yet they were nationalists, even if they had to find the oppressors of their nation within the ranks of their co-nationals.

It may be a mistake to view the multitude of self-declaredly 'national' institutions that proliferated after the fall of the Bastille, such as the National Guard, the National Volunteers, and of course the National Assembly itself, as reflecting nationalism simply due to the use of the 'national/e' prefix; we have seen in chapter one that the word 'nation' was often used in its pre-national sense in French monarchical politics. But evidence that the French revolution was a more deeply nationalist undertaking can be found elsewhere. In a 1792 decree on the functions of the executive council, Article 11 stipulated that:

"La formule Au nom de la Nation et la forme prescrite par les articles precedents seront suivies par le Conseil, par chaque ministre en particulier et par tous les agents du pouvoir executive, pour tous les actes, ordres ou brevets qui doivent être expedies au nom de la puissance executive ${ }^{I 23 "}$

By this decree, the connection between the actions of the government and the concept of the nation

123 Mautouchet, P, Le Gouvernement Revolutionnaire, Paris, 1912, pp144-5. 
is established in a symbolic but salient fashion. For a government to routinely claim to act in the name of the nation might seem mundane but in Europe prior to the French revolution it was unthinkable. ${ }^{124}$ Evocations of nation by pre-revolutionary politicians, as we have seen, were not unknown but tended to be exceptional and vague. The French revolution made them routine but forceful.

The nationalist credentials of the revolution were not limited to words. The revolutionary government undertook actions that were very much in accord with the nationalist project, including the amalgamation of the Papal territory of Avignon into the French state and the formal integration of its neighbour, the feudal remnant of Orange. ${ }^{125}$ It took some time for the nationalist project to be realised in its perfect form, namely the integration of the significant francophone communities in Belgium and Switzerland. ${ }^{126}$ This drive continued even after the Revolution moved into its less cosmopolitan, more xenophobic phase after 1792. In December 1793, this xenophobia had resulted in Anarchasis de Cloots and Thomas Paine, of Prussian and English birth respectively, being expelled from the National Convention despite their French citizenship. But at the same time Jean Marat, born in Neuchâtel of Italian descent, had been freshly enshrined in the pantheon alongside such heroes of the Revolution as Voltaire and Rousseau (a Genevan Francophone). The goal of integration of the French people was not limited to the alteration of international borders. The elimination of feudal privileges and creation of a uniform taxation system throughout France proved a powerful force for national unification.

124 The American revolution was to some degree also a nationalist project, and in this respect was an important antecedent for France.

125 Eric Johnson appears to argue that enthusiasm for the reunification of Avignon with France came largely from Avignon, was based on a pragmatic desire for the urban bourgeoisie to access the French market unhindered by inter-state tariffs, and that the National Assembly moved slowly on the issue, preferring to work towards a comprehensive settlement with the Catholic Church than act rapidly to incorporate a piece of "alienated French national territory. Johnson, Eric F, 'Revolutionary Politics in Avignon' in French Historical Studies, Vol 30, No 1, Winter 2007, pp49-56.

126 Ironically or unsurprisingly this desire to have French speakers within France was not matched by an acceptance of the idea of non French-speakers, such as Alsatians, Bretons or Corsicans, leaving it. 
As mentioned in chapter one, a nationalist awakening of the sort that the French revolution epitomises must be preceded by a period of Gellnerian occultation. The monarchy, known to the revolutionaries with disdain as the ancien regime, was described by them as such a period. Occultation of a national principle is not typically accomplished by repression from those outside the nation, but rather from within. In the eyes of the nationalist the picture is clear. The actions of those in positions of political and cultural power, usually acting out of reasons of narrow selfinterest and hunger for power are responsible. In the words of St Just, Robespierre's right hand man, Louis XVI had 'put himself in the place of the fatherland and tried to alienate affection belonging only to it'. ${ }^{127}$ The nation is removed from its natural place as the central legitimating principle of political life. A nation, in other words, occults itself, albeit not knowingly presumably if the priests and aristocrats truly realised that only through pursuing the goals of the nation could they achieve political legitimacy, let alone personal fulfilment, they would join the national project. Gellner has used the term 'occultation' to describe a phenomena that he feels nationalists rarely acknowledge themselves, but in the construction of the concept of the ancien regime the French revolutionaries come closer than any of their contemporary nationalists would for many decades. ${ }^{128}$

This is not to say that the French revolutionary identification with nationalism is wholly unproblematic. A parallel strand of cosmopolitanism, not to say internationalism, existed among the revolutionaries. This cosmopolitanism would later be manifest in hollow form in the foundation of 'sister-Republics' in territories occupied during the revolutionary wars that were essentially thin facades for French exploitation of conquered territory. But this later faux-cosmopolitan imperialism should not be taken as evidence that French revolutionary cosmopolitanism was always false. On the contrary it had deep roots in Enlightenment thought and the idea of the natural rights of man,

127 Blum, p179.

128 Contrast this with German nationalists, whose 'Second Reich' and 'Third Reich' drew an explicit continuity with previous dynastic states for their post-occultation state. 
both intellectual currents dear to the hearts of the French revolutionaries, which led quite naturally to the idea of a universal human community divided only superficially by nationality. The most conspicuous manifestation of this philosophy were the foreigners representing a 'delegation of the human race' to the Fête de la Fédération in 1790. The delegation was enthusiastically welcomed, as were foreigners present in a more informal capacity ${ }^{129}$. In his 1996 article Michael Rapport examines the speeches, ideas and actions of Robespierre towards foreign states and foreigners within France, persuasively arguing that Robespierre's ideas were shaped by the 'inevitable' xenophobia caused by war, but that a total denunciation of foreigners was absent from revolutionary rhetoric. ${ }^{130}$

It is fair to say that a struggle between cosmopolitanism and nationalism was one of the chief internal struggles of the revolutionary government. The cosmopolitan period identified by Rapport represents the height of this cosmopolitan feeling but it was a brief period bracketed by intense nationalist feeling. Rapport's identification of warfare as a qualifying cause is difficult to agree with, as the decision to go to war is itself a nationalist, anti-cosmopolitan statement. Rapport's identification of cosmopolitanism is helpful in creating a full picture of revolutionary ideology, but it does not weaken the assertion of the French revolution as a nationalist one.

\section{France, Foreigners and the Revolution:}

Criticisms of Marie Antoinette for her ties to Austria were part of a broader context of nationalist denunciation in French revolutionary politics. Marie Antoinette is probably the paradigmatic example due to her prominence, but there are many others. Jacobin rhetorical attacks on Girondins were liberally peppered with references to foreigners directing their actions, thus elevating

\footnotetext{
129 Rapport, Michael, 'Robespierre and the Rights of Man' in French History, Vol 10, No 3, 1996, Oxford University Press, pp309-11.

130 Rapport, pp303-333.
} 
disagreements between factions over policies to the level of treason. ${ }^{131}$ It is even possible that when prominent figures of the Hebertist group such as Danton were put on trial, their accusers took care to include fairly innocuous but overtly foreign individuals, such as the Dutch banker de Kock, specifically because the presence of these foreigners alongside their co-defendants would diminish the national, and thus revolutionary, credentials of the real targets. Robespierre is unlikely to have viewed a living de Kock as a major threat, but a living Danton was.

As the French revolutionaries imagined the existence of a French nation they faced the most basic dilemma of the authentically constituted national community - and indeed they were the original nationalists to face it in Europe, at least from a position of political authority. Although they felt proud that France had achieved a national awakening prior to any other country, and may have suspected that France's unique qualities made it more hospitable to this realisation than its peers, they could not deny that France had peers. Fundamentally a nation was something that had limits. Its limits might be much greater than those it had been constrained to under the period of occultation, as Danton implicitly argued when he claimed France's natural frontier was the Rhine. ${ }^{132}$ And within those borders the nation might be exalted, worthy, admirable and even exemplary when compared to its fellow nations outside of them. But the fact could not be escaped even by scrupulous omission that where France ended, something else had to begin. The only thing nationalists could conceive as existing legitimately outside the borders of their own nation was other nations; any claim made in the name of the French nation could also be made, at least potentially, in the name of those others. It was indeed this idea that led to the cosmopolitanism of Robespierre and the Jacobins.

\footnotetext{
131 Ibid, pp326-9.

132 Although the fact that Danton's proclamation took place during a war means that one should not expect too much ideological clarity in its formulation, it is relevant to note that for all that the Rhenish frontier could be justified on the basis of France as a physical entity with physical boundaries, or even the need for the nation-state to have borders which would allow it to sustain its existence, it differed from the arcane legalistic rhetorical screens Louis XIV used to justify his own expansion in the area only in its ambition - Louis never sought a Rhenish border.
} 
There was a real sense among many revolutionaries that France, as the first nation-state, was the custodian of the genuine national aspirations of the various other European nations while they continued to toil under leaders negligent of the national interest of the people they had captured. This was in a sense a partial extension of the doctrine of personal liberty to the international scene. This custodianship was seen as giving France rights, rather than obligations. These custodial rights for France allowed the revolutionaries to establish continuity with the exceptionalist hegemonic vision of Louis XIV and his successors. It was no great mental feat to go from seeing France as a unique polity for dynastic and sacerdotal reasons to proclaiming a similarly unique vision based on France as the only true self-liberator among nations.

Despite this continuity it was the ancien regime which was seen as the source of the suppression of the nation that caused occultation. France was being held back by French people. Although French royalty had intermarried over the years with royal families throughout Europe, the King and his nearest relatives were born in France, spoke French, and spent the majority of their time in France $^{133}$. Therefore, by the most intuitive definition, they were French, and at least theoretically susceptible to realising their true interest and ceasing to harm the nation. This attitude was held right up until Louis' execution. The hope that the monarch would overcome his own personal occultation and become a true Frenchman, presumably under sufficient tutelage from those with impeccably nationalist credentials, was held by those revolutionaries who wished to see the King's person treated with lenience, and who stressed the educative potential of sparing him. While St Just felt that kingship forever ended humanity, and thus Frenchness, those who voted against the king's execution often seem to have felt that the Frenchman could be extracted from the King.

\footnotetext{
133 The sedentary nature of the French monarchy was not just well established, it was potentially a weakness when dealing with regional interests. Louis XVI left the Paris basin area only twice in his entire life - once to visit naval works at Cherbourg, and once during his flight to Varennes. Had the flight been successful, Louis would have found a very alien world when he arrived in the territories of his brother-in-law; however, the fact that he had no personal experience with any of the diverse regions of the united territory he ruled meant that in all likelihood he found the world of the peasants of the Meuse valley almost as alien - even the French they spoke would have been difficult to comprehend.
} 
Unfortunately Louis and his advisors lacked sufficient discernment to understand the key to his political survival was to assert his national character. When pressed by armed revolutionaries who broke into his private chambers, Louis was more than willing to drink to the health of France, but his instincts were not always so sharp. A century earlier, the removal of the royal court to Versailles by Louis XIV was seen in revolutionary retrospect as an abrogation of nationalism. While obviously Versailles was still within France's borders and populated by people whose nationality was French, it symbolised a conscious retreat from the landscape of traditional political structures which was still highly resonant during the era of the Revolution more than a century later. ${ }^{134}$ In effect Versailles was an artificial island of foreignness within France and in leaving it only when presented with force majeur Louis was unknowingly proclaiming himself foreign. Similarly, Louis' advice that certain aristocratic allies of his should leave France shows a total disdain for, or lack of understanding of, the nationality principle.

\section{The Austrian Woman:}

Marie Antoinette was tainted with perceptions of foreign status all of her own, above and beyond any that came from association with her husband. The very fact that it was so hard for Marie Antoinette to present herself as authentically French meant that she was more aware of the need to do so than was her husband. Attempting to present herself in a French fashion was something that was emphasised to her from the moment she was selected as the bride of the then Dauphin. This attempt was, as we will see, definitively unsuccessful, but whether it was a doomed enterprise to

134 Indeed, the uprising known as the fronde against the regents of the young Louis XIV, which motivated the adult Louis to remove the court to Versailles, was in many ways a proto-nationalist uprising, capturing the two main contributing narratives of the French nation - the traditional, ancient structures of the French people and the mass action of French workers. The fact that the regents the fronde targeted, Cardinal Mazarin and the Queen Mother Anne of Austria, were from outside France, did nothing to harm this national identification. The city of Paris, with its ancient corporate privileges and vast masses of poor, was an emblematic engine of this alliance, and played a correspondingly central role in the fronde, a civic legacy which the municipality continued to proudly present up until the Revolution. The main reason that the fronde cannot be seen as a pretext to the Revolution is that during the fronde the nobility identified themselves and the upholding of their privileges with the proto-national idea while during the Revolution they obviously did not. 
begin with or whether Marie Antoinette did not work hard enough at making herself conspicuously French, she was at least aware of the need. There is no reason to presume that Marie Antoinette was only able to appear as threatening to the French nation. She spoke French well, used it in her daily life and had, by the time of her execution, spent half of her life in France. Her father was a francophone born in Nancy, not at the time part of the French state but a well integrated part of the broader French-speaking world. ${ }^{135}$ It would be wrong to claim that she, or her Austrian or French family, sought for her to 'become French' in any nationalist way. But there was a definite sense that she was leaving one identification behind and assuming another. In the pre-national dynastic system of statehood, members of the royal family are the only people truly able to identify in any sense with the state, as the state is their personal property and governed by their grace. As such, Marie Antoinette had to be symbolically detached from the Austrian state. This was partly achieved by her symbolic stripping of her Viennese clothing and re-dressing in clothing of French manufacture during her first entry into the French Kingdom on a small neutral island in the Rhine. While calling this and other forms of seemingly French behaviour attempts to assume authentically French national characteristics would be anachronistic, it does seem that these acts of conscious abnegation of the Austrian state might have given nationalist revolutionaries some pause for thought in identifying Marie Antoinette as an alien hostile to the French state.

The possibility seems to have existed that if Marie Antoinette could never have been French she had the potential to be seen as a foreigner willing to learn from and be enlightened by the French national project. Yet this did not happen. No journalist, orator or deputy during the revolutionary years, nearly twenty years after she first had come to France, ever felt the need to explain why Marie-Antoinette was Austrian. Her status as Austrian was self-evident. Even those promonarchist commentators who voiced positive views of Marie-Antoinette rarely contested the idea

\footnotetext{
135 Ironically by the time of Marie Antoinette's marriage to the dauphin Nancy had become part of France proper.
} Thomas, Chantal, p143 
that she was foreign to France - they may have argued this foreignness was irrelevant or trivial, but the actual identity of Marie Antoinette was not, rhetorically, defensible ground on which they felt able to make a stand.

During the early period of the Revolution, when the King had a place, however precarious, in the national project, the Queen was conspicuous by her absence. The King may have been made subordinate to the altar representing the Nation during the Festival of the Federation in 1790, but Marie Antoinette was not even present. ${ }^{136}$ At a Festival whose aim was to stress the reconciliation of diverse political factions within the context of the French nation, somebody as obviously nonnational as the Queen was not welcome. Omission was not the only form of attack. A pamphlet circulated after Louis' execution identified Marie Antoinette as 'that loathsome woman, whom the odious House of Austria sent among us to gratify its hatred and its ambitious thirst' ${ }^{137}$. Another, 'Description of the Royal Menagerie', makes insistent reference to the Queen's Austrian origin, referring to her as 'a monster found in Vienna, Austria' and 'The Siren from Austria'. ${ }^{138}$ There is no small irony here: Louis' French upbringing and characteristics are seen as insufficient to ground him in the French nation, which would presumably lead to his being viewed in a more positive light. But Antoinette, despite having a similarly cosmopolitan family tree - she was a descendant of Louis XIII through her father, the Duke of Lorraine, as well as a rather bewildering array of ancestors who reigned in demesnes as diverse as Mantua and Spain, in addition to numerous petty German principalities - is seen as totally and utterly Austrian. A royal upbringing in France did not make one French, but a similar upbringing in Austria made one Austrian. ${ }^{139}$

\footnotetext{
136 Hunt, Lyn, Politics, Culture \& Class in the French Revolution, University of California Press, Berkeley, 2004 , p35.

137 'The Testament of Marie-Antoinette, the Widow Capet' in Thomas, p249.

138 'Description of the Royal Menagerie' in Thomas, pp240-1.

139 The most supreme irony is that the persistent identification of Marie Antoinette as 'Austrian' by her detractors may have been the first appearance of the idea of an authentically Austrian national identity, something that Austrians themselves did not really begin to do with any genuine enthusiasm until the Dolfuss era, and which did not truly crystallise into a universally accepted form until after World War II - making Austria arguably the last Western European nation to accept itself as such. French nationalists were willing to theorise an Austrian nationalism when faced with the issue of Marie Antoinette's commitment to France, but when faced with any other issue in which it might be relevant - for instance, the right to territorial integrity of the 'Austrian' people - this nationalism fell by the wayside.
} 
Monarchies as institutions may be possible to reconcile with the nationalist project, but monarchs as individuals are always problematic unless one is prepared to adopt an extremely reductive personal view. For a while, that view prevailed - Louis was born in France and spoke French as a native, therefore he was French (if not necessarily the ideal Frenchman), while Marie-Antoinette was born in Austria and spoke German as a native, therefore she was Austrian. But the move away from constitutional monarchy made this difficult, and the Jacobin equation of the majority with the nation meant that Louis could no longer be seen as French. Meanwhile Marie Antoinette's status as an Austrian endured. When popular newspaper Père DeQuesne chose to criticise Marie Antoinette in 1790 it did so specifically in terms of her 'hatred of all things French', and when called (apocryphally) to give advice to the Queen on how to appropriately comport herself, the paper's eponymous fictional mouthpiece did not view it as too petty to instruct her to wear French lace rather than Italian, although he also, more seriously, recommended she cease hatching plots with her 'Austrian Cabinet'. ${ }^{140}$

France and Austria:

Of all the states of Europe, Austria and the Empire ${ }^{141}$ was rivalled only by England as an object of hatred by the French political classes. This disdain for Austria was not dependent on a strong French national consciousness, although there was little religious or even geographical basis for a distinct concept of Austrian power to emerge from within the French mind. ${ }^{142}$ Instead, prior to the revolution and the rapid insertion of nationalism into the French polity, dislike of Austria was focused primarily on distrust of its ruling Hapsburg dynasty. This dislike often, ironically, included

\footnotetext{
140 Colwill, Elizabeth, 'Just another “Citoyenne?” Marie-Antoinette on Trial, 1790-1793, History Workshop, No 28, Autumn 1989, Oxford University Press, pp68-9

${ }^{141}$ In France, as elsewhere in Europe the two concepts, and also 'Germany' - in French, 'les Allemagnes” (the Germanies") - were routinely conflated, with many references to the 'German Emperor' ('Holy Roman Emperor of the German nation'). The concept of Austria as something quite separate from the rest of the Empire and/or Germany, was unfamiliar until the post-Napoleonic era.

142 Kaiser, Thomas, 'From the Austrian Committee to the Foreign Plot: Marie-Antoinette, Austrophobia, and the Terror' in French Historical Studies, Vol 26, No 4, Autumn 2003, p582.
} 
sympathy for the various peoples supposedly oppressed by the Viennese court. ${ }^{143}$ For monarchists whose chief loyalty was to the Bourbon family rather than any concept of France, the Hapsburgs were very close to an 'arch-enemy', the natural foes of the French state since such defining moments of its diplomatic-military history as the Thirty Years War. The goals of the House of Bourbon and the ancien regime in international relations were often negatively defined in opposition to Hapsburg goals. The reverse was also true. Even during the years of the FrancoAustrian alliance francophobia was strong in the Austrian royal house, possibly due to the role of Francis of Lorraine, the husband of Maria Theresa, who had lost his Duchy to Louis XIV's reunions, in promoting a vigorous suspicion of the Bourbons among his sons. At the same time the Duc de Choiseul experienced extreme difficulty in his attempts during the reign of Louis XV to sustain a durable alliance with Austria. The Franco-Austrian alliance even once signed was treated with unvarying scepticism by almost all elements of the French elite beyond Choiseul's immediate circle.

Historian Thomas Kaiser argues that hostility towards the Queen in the pre-revolutionary period was motivated by hostility towards Austria. ${ }^{144}$ It is worth questioning, however, the degree, if any, to which this Austrophobia was expressed outside the policy-making elite. Did the bourgeoisie, let alone the urban poor and peasants who were to occupy roles in the upcoming revolution, hold similar views? Kaiser's work is often not specific about exactly who held Austrophobic views. He points out the foreign ministry's obsessive recording of assassinations and treaty breaches by the Hapsburg state, but it is extremely unlikely that the average French peasant or sans culotte had any idea what the Treaty of Westphalia was, let alone what constituted a breach of it or exactly how such a breach cast the Hapsburgs in a bad light. Pre-revolutionary Austrophobia, while extremely potent insofar as it went - again, the tremendous institutional obstacles to a meaningful alliance

143 Kaiser, 'From the Austrian Committee etc', p583.

144 Kaiser, Thomas, 'Who's afraid of Marie Antoinette?' in French History, Vol 14, No 3, 2000, pp241-71. 
with Austria cannot be over-stressed - were essentially based on the idea that the Hapsburgs were endemically hostile to France and French interests. The subjects of the Hapsburg family were virtually ciphers in this narrative, active only as agents of a perfidy which was intensely personal, or at least familial. Foreign policy as a whole could not have interested most French subjects, except to the extent that it affected the price of goods they might wish to buy. The Austrophobia identified by Kaiser, which we might identify as 'thin' in that it affected only a narrow strip of society, needs to be treated with caution not specifically because it was thin but because it cannot be said to have been popular. Conversely, when the very words 'Austrian Committee', appearing in broadsheets with a mass circulation, such as Pere DeQuesne, were considered sufficiently evocative to need no elaboration in order to have their desired effect, a popular Austrophobia is definitely in effect, but needs further explanation than Kaiser can provide. It is not enough to simply accept it as the continuity of dynastic thin Austrophobia without further explanation.

The nationalist approach to Austria in France can be illustrated by providing a contrasting model that of the approach to England. Kaiser identifies England as the other state marked out for 'extermination' by revolutionary war era officials. ${ }^{145}$ Despite this, England was consistently identified as the only other state that enjoyed a genuinely national existence. Some revolutionaries viewed England in a positive light, presumably for this reason. A clear 'English model' existed and was often specifically evoked, particularly during the early stages of the Revolution when some role for the King was still envisaged. In 1790 the Jacobins of Nantes indulged in a positive orgy of proEnglish activity, including celebrating the Magna Carta and sending a delegation to London. ${ }^{146}$ In a speech by Merlin de Douai to the National Assembly in 1790, the deputy contrasted England with Austria, stating that England (similarly to France) represented:

145 Kaiser, 'From the Austrian Committee', p579.

146 Rapport, p311. 
'une seule nation, un seul État, une seule association d'hommes civilisés et réunis par un même pacte'. ${ }^{147}$

It is possible that Douai merely intended to describe the fact that the borders of the English state circumscribed a fairly homogenous ethno-linguistic community, not that the English government was actively embracing the national principle in the same way that its French neighbour did. However, the very fact that he saw no need to clarify this, and that he employed it in a comparison with Austria that was clearly intended to be critical, shows a certain regard for England that is unparalleled in consideration of any other state. However, there was also considerable anti-English sentiment. In his study of Robespierre's views on foreign states, Rapport identifies numerous occasions on which Robespierre would denounce not just the English government but the English way of life and culture - effectively, the English nation itself. In one speech Robespierre openly stated that 'I hate the English people', and in a later proclamation he ordered that no prisoners be taken when English armies were defeated. ${ }^{148}$ Robespierre seemed to feel that England, even though it already constituted a nation-state, was failing in its fraternal duty to support its fellow nation-state in France. The genuine anger directed at England was due not least to its alliance with a nonnational state, Austria. Effectively England was failing to fulfil the pastoral duty that the French nationalists envisaged for their own state. England was complicit in the continued suppression of other European nations, not least in its collaboration with Austria. Thus the shared hatred of England and Austria by French nationalists, while it may seem to portray a contradictory approach to national identity in foreign states, is in fact consistent. Austria was a target of anger for embodying a pre-national Europe, while England was a target of anger for embodying a national Europe but refusing to act on this embodiment - indeed, acting actively against it.

\footnotetext{
147 Douai, Merlin, 'Report on the claims of the German princes owning seigneurial properties in Alsace' in French Revolution Documents, Vol 1, JM Roberts and RC Cobb eds, Basil Blackwell, Oxford, 1966, p437.

148 Rapport, pp323-4.
} 
Marie Antoinette's connection to this suspicion of Austria goes beyond her heritage. Her marriage to the dauphin in 1770 was the most tangible result, beyond even the formal alliance negotiated by Choiseul, of Franco-Austrian friendship. Accusations that she was in the service of her brother, the Emperor Josef II, followed hard on the heels of the Diamond Necklace Affair. ${ }^{149}$ This narrative would continue to grow, with a particular and somewhat hard to explain emphasis on her supposed predilection for draining the French treasury and sending the money to Austria.

Although not every accusation was true, Marie Antoinette did attempt to influence court politics in the direction of Austrian interests. She was not conspicuously successful in doing so. Generally she was associated with the courtly group consisting of former beneficiaries of the patronage of the Duc de Choiseul, who attempted, without success, to get the Duc restored to his office as Foreign Minister and de facto Chief Minister. Marie Antoinette even arranged for him to be personally presented to Louis XVI on the occasion of the latter's accession to the throne, presumably with the intent of having him restored. ${ }^{150}$ As Choiseul's signature policy was cooperation with Austria, the Choiseul faction, while not necessarily bereft of the Austrophobic assumptions which Kaiser identified among ancien regime elites, had a strong interest in presenting a favourable view of Austria. ${ }^{151}$ There certainly seems to have been an expectation among Austrians that Marie Antoinette would make the case for their interests - during the Bavarian succession crisis of 1777 Comte Mercy D'Argenteau, the Austrian representative in Paris, worked hard to persuade her to support Austria's claim to incorporate the Duchy of Bavaria into their territories. ${ }^{152}$

\footnotetext{
149 Maza, p92.

150 Belloc, Hilaire. Marie Antoinette, Methuen, London, 1917, p54. Belloc argues that the Austrians would have preferred a different pro-Austrian minister appointed and that Marie Antoinette's attempt to present him to Louis was based purely on a fond personal attachment.

151 And correspondingly a negative view of Prussia - usually viewed as a more rewarding ally by the anti-Choiseul faction. The pre-nationalist paradigm of courtly elites is illustrated by the fact that there appears to have been no constituency for a policy of non-intervention in German affairs.

152 Belloc, pp105-6, 117-8.
} 
Prior to the flight to Varennes in June 1791, nationalist criticisms of Marie Antoinette that arose during the revolutionary era centred on the idea of the 'Austrian Committee'. This assertion found its way into the deliberations of the National Assembly, when Francois Chabot claimed that he could 'prove the existence of an Austrian Committee'. ${ }^{153}$ The fact that Chabot felt no need to explain exactly what this committee was but instead launched into an explanation of how he could 'prove' its existence shows that the concept was sufficiently popular, presumably thanks to the efforts of Hebert at Pere DeQuesne and his various imitators, that the deputies of the Convention did not need to have it explained to them. Those accused of being members of the Committee included Dumouriez, Philippe D’Orleans and Bonne-Carrere ${ }^{154}$. It is worth noting that none of these men was Austrian, none had any substantial connection with either the Austrian state or region and none had ever been to Austria. 'Austrian' had become a sufficiently negative term that it had escaped its literal meaning, at least in the context of the committee. Austria had gone from being a foreign country to being the archetypical foreign country. When revolutionary orators needed to evoke fear of the foreign, it was inevitably Austria that they used. This meant that Austria had to bear, to a certain extent, the burden of any hatreds, suspicions or resentments directed at any given foreign state, to say nothing of those less clearly formulated but undeniably equally strong resentments directed at 'foreignness' in general.

The 'thin' dislike was gone. So was the idea of Austria as a disruptive force in the European state system. The republicans for the most part saw that system as itself a corrupt product of royal decadence and were rather proud of the way they broke its rules, even if they did not see themselves as treaty-breaking assassins like the Austrians. But while previously Austria's non-national nature had been unexceptional, and 'thin' Austrophobia had operated despite it, now this non-national

153 Buchez, Phillipe-Joseph-Benjamin, Histoire parlementaire de la Revolution Francaise, ou Journal des assembles nationals depuis 1789 jusqu'en 1815, Paulin, Paris, 1838, p4. Translation is the author's own.

154 Buchez, p6. Dumouriez would later betray the Republic to the Austrians and serve the English during the Napoleonic wars. Bonne-Carrere was his ally, although his role was quite minor and he was able to plead for clemency and return to private life. Orleans, Louis XIV's cousin, was later condemned to death and guillotined. 
nature made Austria a target, even a magnet, for hatred. In his speech on the rights of German princes to feudal incomes in Alsace, Merlin Douai explained that there existed amongst the states of the empire:

'...une confederation qui a pour chef l'empereur, et pour centre la diete de Ratisbonne; mais cette confederation n'empeche pas que chacun d'eux ne soit mâitre des ses alliances, que chacun d'eux ne puisse faire la guerre a ses co-États, que chacun d'eux, en un mot, ne forme un corps de nation sépare'. ${ }^{155}$

In other words, the empire was not a nation state at all, merely a collection of nation-states, each of which could presumably theoretically be dealt with on equal terms (and none of which could lay claim to feudal 'rights' beyond the borders of their particular territories, e.g .in Alsace); the totality was a simple nullity. Although French diplomacy with Austria remained proper and formal even throughout the revolutionary period, animus towards the Austrians was extremely potent. ${ }^{156}$ Austria was seen as a strong example of the opposite of the national principle that the revolutionaries so firmly invoked. Had Marie Antoinette belonged to the House of Hanover (the ruling dynasty in Great England and the German state of Brunswick-Lüneberg) rather than the House of Hapsburg, she probably would have continued to face hostility due to being associated with an enemy state during a time of war, but in her own person she would not have been seen as an intrusion of anti-national dynasticism into the French political arena.

155 Douai in Roberts \& Cobb, ed, p437

156 The $19^{\text {th }}$ century formulation of Austria as a 'prison of nations' is not entirely appropriate, since there was little popular appreciation for the suffering of charismatic minorities such as the Magyars or Poles at the hands of Vienna as there would be sixty years later, but the concept is broadly similar. 
The royal family's flight to Varennes, unsurprisingly, provoked an explosion of nationalist commentary. The event was seen very much as a fulfilment of nationalist fears. The official explanation that the royal family had been taken against their will was initially intended to defend them against the notion that they had attempted to voluntarily abscond. However, when publicized, this fiction became the worst of both worlds. In promoting the concept that the royals had been kidnapped, the government emphasised strongly the role of foreign nationals, such as the erstwhile 'kidnapper' Fersen, his sovereign the King of Sweden, and the Emperor of Austria, the ultimate provider of safe haven. Indeed, the image of the King and Queen fleeing into the arms of her brother the Emperor Leopold II (who had succeeded Josef II in 1790) to protect them from the French people could not have been calculated to be more offensive to the nationalist audience. At the same time, however, in exaggerating the role of the 'kidnappers', the official line was not able to downplay the fairly obvious credulity of the royal family. But it is notable that the focus once again was on the Queen - the public seemed to be prepared to believe Louis had been duped or compelled, rather like the royal children, if not actually kidnapped, but Marie-Antoinette was promoted to the role of active conspirator.

The Varennes flight was perfectly illustrative of nationalist critiques, in that it had the royal family both symbolically and actually abandoning the nation while continuing to aspire to affect its politics. It should not be considered surprising that the popular hysteria that broke out following the flight to Varennes was distinct from more general revolution-era fears of violence and hoarding in that it had a particularly national character and the theorised threat was from imaginary foreign armies and navies, not from relatively a-national brigands, the usual suspects of dark deeds during other, similar outbreaks of revolutionary panic ${ }^{157}$. It was not even possible to see the Varennes flight

\footnotetext{
157 Tackett, Timothy, 'Collective Panics in the early French Revolution 1789-91: A Comparative Perspective' in French
} 
as an alien body ejecting itself, and thus achieving a goal most nationalists would agree with. It quickly became clear that the royal family sought to remove themselves from the nation in order to be better positioned to shape its public life towards their own, presumably anti-national, ends. From a monarchist redoubt on the Austrian border, or from within Austrian territory, they would be free to act; when surrounded by the people of Paris, the French nation in its most concentrated physical form, they could not. Although nationalist rhetoric against Marie Antoinette obviously continued well after the flight to Varennes, persisting up until her death, the Varennes flight set both the tone and the content of that rhetoric and indeed continued to do so for a significant period after her execution. The formal sentencing at her trial was addressed to 'Marie Antoinette of Austria'.

At the trial of Marie Antoinette, the criticisms of the anti-Choiseul party proved to be surprisingly durable, but they were re-written, not as a matter of rival dynastic interests, but as being against the 'natural' interests of France - for France to fully be France, it seems, it could not be in cooperation with Austria. When Dumouriez needed to justify revolutionary France's declaration of war on Austria, his speech to the National Assembly explicitly invoked Austria's prior wars with France. ${ }^{158}$ The revolutionary position, at least at the time of Marie Antoinette's death, maintained that hostility to Austria had been one of the expressions of national identity that survived during the period of ancien regime occultation. Of course Austria, in waging war against France, was making it easier for Dumouriez and the Queen's prosecutors to draw this connection. But it seems strange that the policy of dynastic warfare which led so directly to the financial crisis which resulted in the monarchy's downfall was somehow seen as one of the only 'good' things the Bourbons had done, from a national perspective. Indeed, as if not trusting French nationalists to make the connection, the Emperor specifically stated in the Declaration of Pillnitz that Louis XVI was "an object of common interest to all the sovereigns of Europe". ${ }^{159}$ This evocation of a common brotherhood and

\footnotetext{
History, Vol 17, No 2, 2003, pp161-3.

158 Kaiser, 'From the Austrian Committee etc', p269

159 Roberts and Cobb, p439. Translation is the author's.
} 
interest between sovereigns clearly evoked a politics that was pre-national - but, given that the appearance of nations on the political scene had a transformative effect, in the eyes of the revolutionaries there could be nothing pre-national, only anti-national. The cosmopolitan dynastic world of monarchical common interest could not simply be allowed to wither if it insisted in imposing itself, both militarily and, as in the declaration of Pillnitz, conceptually, on the new national world that the French revolutionaries saw themselves attempting to build.

A similar phenomenon occurred during the final days of Marie Antoinette's life. Her nephew, Francis II, who had succeeded Leopold in March 1792, attempted to procure her freedom for military concessions. However this concern for Marie Antoinette, whether it was phrased by Austrian intermediaries as a dynastic desire to secure the safety of a member of the imperial family, or a "Pillnitzian" concern for a fellow monarch, was calculated to offend the French revolutionaries, who proved unresponsive and resolute in their determination to see the Queen die. Whether these negotiations by the Austrians were aimed seriously at securing the Queen's freedom is an interesting question, but the main thing to be taken from this episode is that the revolutionaries continue to see any connection between Marie Antoinette and the Austrian state as illegitimate and anti-national. Pere Duchesne made the connection explicit, promoting the execution of the Queen as a rejoinder to the Emperor's persecution of revolutionary France. ${ }^{160}$

\section{$\underline{\text { Marie Antoinette as a foreigner: }}$}

Marie Antoinette was not simply a foreigner, she was a foreigner who occupied a privileged place at the head of the state; a foreigner who hailed from a foreign location that was not only outside the nation but represented an abnegation of the nation. Even if Austria had not gone to war with France it is likely she would have been the target for just as fearsome a denunciation as she received.

160 Colwill, pp75-6. 
Effectively her offence to the national project was too profound to be limited to simply denouncing her as a person - so alien was Marie Antoinette to the nationalist project that she had 'alienation to spare', and the outrage evoked by her supposed and actual actions could be relatively easily transferred to others whom the promoters of revolutionary discourse wished to disassociate with the authentic nation. The most obvious victim of this was Louis XVI - apparently not entirely satisfied with promoting the idea that he was un-French due to the non-national basis of his claim to power, the revolutionaries found it much more profitable and satisfying to repeatedly emphasis his supposed submission to his Austrian wife. The same is true of those members of the supposed ‘Austrian Committee' and of the Queen's personal household. 


\section{CHAPTER FIVE:}

\section{RUSSIA AND NATIONALISM}

One of the many similarities between the French and Russian revolutions is that both were nationalist revolutions. The Russians who overthrew the Czars proclaimed they did so in the service of a Russian nation. The nation offered a source of legitimacy sufficient to justify removing leaders incompatible with the needs of the nation. The parallel with French revolutionary nationalism is not exact. The Russian revolutionaries had a better case for seeing the Russian nation as threatened than their French counterparts did. The relationship between the Russian nation and the late Imperial Russian state was complex. Aligning nation and state was much more problematic than it was in France. Peter Struve's brazen attempt to square this circle involved asserting that the Russian nation was the Russian state. But even if we accept Struve's assertion Russia's existence as a nation remained threatened simply due to the military threat posed by Germany.

Like their French counterparts the Russian revolutionaries favoured national terminology. They lacked opportunities to set up institutions comparable to those which their French predecessors festooned with the prefix 'national'. The primacy of nationalism was demonstrated in other ways. The Nationalist group in the Duma was the clearest example of a political group identified with the principle of nationalism, even if it was initially a pro-Czarist party. The removal of liveried doorkeepers from the corridors of foreign ministry under revolutionary Foreign Minister Pavel Miliukov was as much a desire to remove Franco-German style of dress as it was a concession to wartime austerity. ${ }^{161}$ There was a special regard for the work of Russian writers and artists, such as Dostoevsky, Tolstoi and Pushkin. ${ }^{162}$ This desire to use the label of nationalism endured until well

\footnotetext{
161 Stockdale, p252

162 Tolz, Vera, Inventing the Nation: Russia, Oxford University Press, New York, 2001, pp201-2.
} 
after the Bolsheviks had taken power, when a movement by former Duma politicians to oppose the Red Army proclaimed itself the 'National Centre'. ${ }^{163}$

The nationalism of the revolutionaries did not confine itself to symbolic expressions. The most nationalist decision made by the revolutionaries who made up the Ministry of the Provisional Government was the decision to continue the war against the Central Powers. The decision to prosecute war is one of the most sweeping and consequential decisions a nationalist policy-maker can make. It could be argued that by merely pursuing an existing foreign war, unlike their French counterparts who started a war, the Russian nationalists were not displaying nationalism so strongly. It is certainly true that all other things being equal it requires stronger motivations to start something than to continue something pre-existing. More persuasively, it could be argued that in choosing to continue a war which had cost Russia greatly the Russian revolutionaries displayed more nationalism than their French predecessors, who did not have to carry with them a public sceptical of war. Although a desire to be seen by the allies as a good international citizen and a legalistic desire to promote continuity contributed to the Provisional Government's wish to fight, they were secondary to the need for national agrandisement.

\section{Occultation in Russia:}

Gellner's concept of occultation in regard to the pre-revolutionary period applies as aptly to Imperial Russia as it did to ancien regime France. The degree of continuity between prerevolutionary, non-national and post-revolutionary, national administrations was greater in Russia. 164 The concept of occultation remained extremely relevant. It was simply the point at which

163 Smele, Johnathan D, Civil War in Siberia: The anti-bolshevik government of Admiral Kolchak, 1918-1920, Cambridge University Press, Cambridge, 1996, pp57-8.

164 Most of the Provisional Government's ministers had been members of the Duma or the Zemstvo local government organisations prior to the 1917 revolution, although none had had a role in public politics prior to 1905 . 
occultation ceased that was generally moved forward. Before 1905 the emancipation of the serfs in 1861 was often seen as the tipping point when Russia became Russian. After the events of 1905 the emancipation retreated in nationalist consciousness and was replaced by the granting of a Duma as the end of occultation. Peter Struve was representative when he looked back approvingly to 1905 as a 'transformation', a 'metamorphosis', a time where 'intelligentsia thought coincided with popular thought'. ${ }^{165} \mathrm{He}$ even went so far to describe the main product of the reforms of 1905, the Duma, as a 'national' assembly despite the fact that the Duma's members described the body in purely Imperial terms. In 1917, as new problems manifested and were once again interpreted as a threat to the national status of the Russian state, the end of occultation was advanced to the contemporary.

Of course the Russian revolution, like the French revolution, was no discrete event, and those who wish to problematise the assertion of the revolution as a nationalist one will find many examples to prove their point. Powerful counter-nationalist ideas were at work during the Russian revolution. The diplomatic concern for Russia's position as a dutiful member of the community of Great Powers has already been alluded to. Similar in spirit but felt on a more popular level was the internationalism of the working classes who felt a sense of community with foreign workers, even if foreign governments were distrusted. ${ }^{166}$ This phenomenon was given theoretical expression and political prominence by Lenin, whose enthusiastic advocacy of revolutionary defeatism, while not always popular, was a strong expression of hostility to nationalism.

Nonetheless it is not difficult to identify a perceived need to preserve and enhance the nation-state, and to end occultation, as one of the driving goals of the Russian revolution. As such the revolutionary's targeting of Alexandra Fedorovna for public criticism as a technique to diminish

165 Struve, P, 'Intelligentsia and Revolution' in Shragin and Todd, pp145-6.
166 Read, p83 
respect for the monarchy must be seen as an attack by nationalists. We can expect to find many examples of her status as a foreigner being highlighted and criticised.

\section{The Czarina's Dark Shadow:}

In writing about the Czarina some mention of Rasputin is unavoidable, but the reader could be forgiven for thinking that this chapter, and those other chapters in this paper focusing on the Czarina, is devoted entirely to the study of Rasputin, with the Czarina as a footnote. The emphasis on Rasputin's activities in a paper that purports to be concerned with the image of his patroness deserves defending.

Grigori Efrimovich Rasputin was a Siberian peasant who came to prominence in St. Petersburg society by presenting himself as a follower of the Orthodox tradition of the starets - a holy wise man who speaks truth to power. Rasputin promoted himself as the possessor of thaumaturgical gifts, including hypnotism and healing. He held no public office in the Russian government or even in the church hierarchy. ${ }^{167}$ His sole attempt to gain an official position, namely an appointment as the Czar's personal confessor, failed due to his inability to meet the basic literacy requirements for admission to the Orthodox priesthood. ${ }^{168}$ Despite this lack of public office he was able to affect very considerable power over both secular and religious governance. Several bishops, notably Varnava of Tobolsk, owed their positions of authority almost entirely to his influence. Varnava was so confident of Rasputin's ability to shield him from the Church hierarchy that he canonised Saints on his own initiative and received only nominal punishment. ${ }^{169}$ Similarly, the appointment of

\footnotetext{
167 Thanks to the reforms of Peter the Great, at the highest levels there was no separation of powers - the Orthodox Church in Russia was governed by the Holy Synod, a lay institution that integrated church figures but was headed by a Cabinet minister, the Prokurator, responsible to the Czar.

168 Figes, pp29-30

169 Freeze, Gregory, 'Religion and the Political Crisis in late Imperial Russia' in The Journal of Modern History, Vol 68, No 2, pp342-48.
} 
wartime prime minister Boris Sturmer was largely thanks to Rasputin's influence on the Czarina. ${ }^{170}$

The appointment of politicians is a good example of the manner in which, at the apex of his prestige, Rasputin's status as a patron was exercised almost entirely through the Imperial family, and within the Imperial family primarily through the Czarina. The public perception was that it was the Czarina, with her even greater concern for the health of the Czarevich and her Orthodox piety literally the zeal of a convert - who was most susceptible to Rasputin's appeals. ${ }^{171}$ In her correspondence with her husband regarding the appointment of Alexander Protopopov to the Ministry of the Interior, a portfolio Rasputin was keenly interested in, Alexandra was willing to allow herself to be guided sufficiently as to recommend that Protopopov be given the office, not once, but three times, despite the fact that she had never met him. ${ }^{172}$

As such it is impossible to extricate views on Rasputin from views on Alexandra. The question of whether she would have become so closely involved in the governance of the Russian state, particularly when it came to the appointment and dismissal of ministers, without Rasputin's pressure on her to assume such a role is an interesting one but one that this piece will not attempt to address. The analogy of Marie Antoinette and the Comte D'Artois or Count Fersen is an apt one we are concerned not with whether or not any connection existed but with the undoubted public perception that there was a connection.

\section{Rasputin as non-national:}

Even if it is accepted that a discussion of Rasputin is not out of place in a work that takes his

170 Fuhrmann, Joseph T, Rasputin, Praeger, New York, 1990, pp172-4.

171 Ironically, the Czarina had been extremely resistant to the idea of converting from the Protestantism of her upbringing to Orthodoxy, to the point where it represented the main barrier to her marriage to the then Czarevich, but after making the move to the Eastern rite she practiced an extremely high level of devotion even before the appearance of Rasputin.

172 Fuhrmann, p180 
patroness as its main point of reference, the starets' mention in a chapter that purports to cover specifically nationalist criticisms of Alexandra Fedorovna may seem difficult to justify. Rasputin's relationship to Alexandra has obvious referents to any perspective on the Empress that focuses on issues of tyranny and despotism, to say nothing of gender. But his appearance in this chapter, focused as it is on the revolutionaries' increasingly successful attempts to cast Alexandra as outside the Russian nation, may come as a surprise. Not only was Rasputin Russian, he was arguably the epitome of Russian-ness. His traditional clothing, unkempt beard, lack of education and monolingualism were a stark contrast to the westernised appearance, cosmopolitanism and multilingualism of most of the nationalist revolutionaries who would denounce Rasputin so firmly in the Duma.

None of the rumours, denunciations or public attacks on Rasputin contemplated the idea that he was from outside Russia in the sense that Alexandra Fedorovna was. Rasputin's birth in Siberia, from incontestably ethnically Russian stock, was a matter of record. Those of ethnically Russian descent were vulnerable to being de-nationalised in the public discourse by revolutionary propagandists, however, and Rasputin was no exception to this vulnerability. The idea that Rasputin was nonRussian relied on two assertions, one relatively shallow, and one deep. The first assertion rested on his position as an obstacle to the war effort, the second on his status as a member and representative of the peasant class.

The nationalist discourse in Russia in the nineteenth and early twentieth centuries had a fraught relationship with Russia's peasants. The frequent formulation of the 'peasant question' was one that explicitly placed the peasantry outside the decision making body. A useful referent is the 'Irish question' in contemporary England. After the emancipation of the serfs much effort was directed at attempting to more fully integrate the peasantry into the Russian nation, an end that was a major 
driver of both the land laws passed by reformist prime minister Piotyr Stolypin and the expansion of military service, although always with very limited results. ${ }^{173}$ The view of the peasantry as an unknown, unknowable, dark mass was part of what led to the rapturous reception given to Maxim Gorky when he first began to write. Although Gorky was a talented author it was not this that elevated him into the literary pantheon alongside Tolstoi, Gogol, Dostoevsky and Pushkin; it was the fact that he was the first great Russian author to arise from among the peasants, giving him the quality of an ambassador from an alien but nonetheless crucially important foreign place. For some of the earlier branch of conservative slavophile nationalists this primal mysteriousness was a source of political legitimacy for the peasants. When Konstantin Aksakov stated that 'you cannot count the age of the people' it was a compliment aimed at contrasting the 'people' favourably with what he saw as the shallow, westernised idea of the 'public'. But even the valorisation of the alien qualities of the 'people' attributed to the people - by which he meant the peasantry - the status of a body beyond quantification, comprehension or understanding. ${ }^{174}$ In France at the same time the inheritors of the revolution were struggling to inform the peasantry through a massive educational project of exactly what it meant to be a part of the French nation; it is likely that their Russian counterparts felt the same way, if not more so. ${ }^{175}$

Pavel Miliukov ${ }^{176}$, a politician who would later rise to the position of Minister of Foreign Affairs in the revolutionary government and who occupied a senior position in the Constitutional Democrat party prior to 1917 , told his fellow Duma members that 'the nation is adaptable, it changes, it expresses itself... it prepares for the morrow'. ${ }^{177}$ In conscious opposition to the pseudo-nationalist tradition of slavophile conservatives who saw Russia as an unchanging primal society, Miliukov associated the nation with energy, innovation and openess. While this formula was ideal for

173 Tolz, pp103-4.

174 Quoted by Tolz, p86.

175 Weber, Eugen, Peasants into Frenchmen, Stanford University Press, Stanford, 1976, pp330-8.

176 Also sometimes known, particularly in his later writings, as Paul Miliukoff or some variant thereof.

177 Stockdale, p188. 
persuading members of the upwardly mobile middle classes and even ethnic minorities to identify with the Russian nation, it alienated the uneducated, unambitious peasantry. According to lectures Miliukov delivered, a nation was an entity formed by voluntarism that required its members to actively invest in it ${ }^{178}$ This was intended in a spirit of inclusiveness, and certainly held out a welcoming hand to various members of ethnic minorities such as Jews, Germans and Ukrainians who were interested in playing a part in the Russian national endeavour as long as room was made for them. Conversely it closed the door to anybody who did not respond to the call for volunteers.

This view of the nation, which was shared by many of Miliukov's political allies, offered ample grounds to disqualify peasants from membership of the nation. Any attempt to measure peasant engagement with the state against Miliukov's voluntarist criteria would have resulted in the conclusion that peasants did not identify with the nation. Not only did the peasants who made up the bulk of the Imperial armies frequently desert, they often expressed scepticism that they should identify with Russia as a whole, as opposed to their own localities, which they often felt were outside the plausible reach of the German armies. ${ }^{179}$ This lack of engagement with the state was not limited to the military during wartime, as peasant participation in elections to the Duma was characteristically very low even before the war. ${ }^{180}$ If it was possible, as Miliukov argued, to choose the nation, peasants were not choosing it.

It would be an oversimplification to see Miliukov's voluntarist-nationalism as the only view on the peasantry held by the Russian liberal-revolutionaries. The ideas of Peter Struve, a former Marxist and liberal journalist who was a sometime ally, sometime antagonist of Miliukov initially appeared to offer a different view of how the masses of Russian peasants corresponded with the existence of the Russian nation. In a speech to an English audience during World War One Struve portrayed the

\footnotetext{
78 Ibid, pp186-87.

179 Tolz, pp180-1.

180 Tolz, pp104-5.
} 
peasantry as forward-looking and innovative, as often 'serfs' only in a technical sense, and as playing a major role in Russia's great power projects such as the independence of Serbia and Bulgaria and expansion into the Black Sea. ${ }^{181}$ On the surface this seems to be a rebuttal to Miliukov's unintended contempt for the peasants. Struve did not, however, even partly refute Miliukov's voluntarist assumptions; quite the contrary, he confirmed them in his questioning. Struve's Russia included serfs and peasants because they actively involved themselves with the national project - what better demonstration could there be of their sense of belonging to Russia and sharing its goals than their assistance in such high projects of statehood as the seizure of the Dardanelles? Struve clearly felt that the best way to ask the question of whether peasants were Russian was to assess their levels of voluntarism, not to question whether voluntarism was the appropriate criterion. And once again, there was little evidence of the voluntarism Struve advocated. Indeed while he may not have intended it as such the (supposed) participation of Russian peasants in the state's relentless drive towards Constantinople during the $18^{\text {th }}$ century that he emphasised stood in strong contrast to their current reluctance to involve themselves in the latest leg of the ongoing march to the Dardanelles.

Introducing Rasputin into this context had predictable results. While nationalists such as Struve and Miliukov were generally uncomfortable with explicitly stating that they felt the peasantry were incapable of participating in the nationalist project, criticising specific peasants was clearly a more feasible project. Rasputin was the highest profile member of the peasant class to be found in Russia at the time due to his dogged refusal to trade in his peasant clothing and mannerisms for those more appropriate to a confidant of the Czars. It would be a mistake to portray Rasputin's vague pseudopolitical invectives to the Imperial family on the subject of a union between the Czar and the people as a political theory of any type, except insofar as they represented the starets idea of what his

181 Struve, Peter, 'Past and Present of Russian Economics' in Russian Realities \& Problems, J.D. Duff ed. Cambridge University Press, London, 1917, pp 59-61, 64-5 
audience wanted to hear. ${ }^{182}$ In a sense they were connected to the conservative, pro-peasant nationalism of the late $19^{\text {th }}$ century, but only in the form of loose parody. Those who continued to hold such views were often extremely hostile to Rasputin. One such conservative, Vladimir Purishkevich, a founder of the ultra-conservative Order of the Archangel Michael, participated in the starets' assassination. But even if we take Rasputin's views as the product of a genuinely nationalist philosophy centred on the Russian peasantry and rejecting the westernised bourgeois of which Miliukov and Struve were representatives, this would have only heightened their nationalist antipathy towards him. As any study of the history of nationalism clearly shows, conflicts between rival groups of nationalists as to which group within society most perfectly embodies the nation can be extremely bitter.

\section{Nationalist criticisms of the Sturmer Ministry:}

Rasputin was not the only non-Russian figure who Alexandra was associated with. In 1916 following the resignation on grounds of age and ill health of Ivan Goremykin, at the urging of Alexandra and Rasputin, Boris Sturmer was appointed prime minister of Russia. Sturmer's period of rule, which lasted for most of 1916, coincided with a steadily rising tide of denunciations of Czarist government, and the Czar's abdication followed his own departure from office by only three months. Sturmer was widely seen as the puppet of Alexandra and Rasputin and his time in office is generally connected to the Empress' period of greatest power. After the Imperial couple and Rasputin, Sturmer was the most hated person in Russia by the time of his dismissal. We will return to Sturmer's time in office in later chapters, but his name is not out of place when reviewing nationalist critiques of the Czarina.

$\overline{182}$ For an example of some of Rasputin's attempts at political commentary, see Fuhrmann, pp102-3. 
Although Boris Sturmer had been raised in Russia, was a practicing Orthodox Christian, spoke Russian fluently and generally possessed a wide range of the traits necessary to present himself as a credible member of the Russian national community he appeared non-Russian in one crucially conspicuous manner - his surname. Sturmer's ancestry was as grounded in Russia as many of his political foes, but his name, derived from an Austrian paternal ancestor, immediately drew attention to origins that were, like the Czarina's, not just generically foreign but explicitly tied to Germany the wartime enemy. Given that the conservative courtly faction who engineered Sturmer's appointment to the post of Premier presumably did so in the expectation that he would facilitate rather than hinder their desired policies, it can only be presumed that they either did not anticipate his being perceived as foreign or thought it would not be a problem. While this attitude might seem naive in the context of an environment characterised by contentious nationalism, where conservatives had begun to take steps to reconcile Russian nationalism with autocracy, there was persuasive evidence to the contrary. Sturmer himself, displaying a level of discernment that his patrons lacked, began to take steps to change his name to 'Panin', notably petitioning the Czar to allow him to do so. The request never went through since Nicholas insisted on consulting all existing members of the existing Panin Princely family before granting it.

Sturmer's surname was only the first evidence of foreign-ness that his political opponents unearthed. A non-Russian sounding surname was not generally out of place among the Russian elite. The Czars had generally been surrounded by a penumbra of institutions and offices with nonRussian names. Even among the liberal nationalists of the Duma deputies there were many whose extra-Russian descent was equally obvious through their surnames, such as Petr Struve. Ironically one of the first and most original theorists of the particular brand of Russian nationalism that would animate the February revolutionists, Struve's German-Danish ancestry never once evoked comment despite some extremely heated exchanges with other Russian intellectuals on the topic of national 
identity. And yet Sturmer's surname was not simply a burden, it was a crushing one. One political verse that coincided with Sturmer's appointment as foreign minister (after serving as prime minister for five months already) depicted him singing "Deutschland uber alles", compared him to Bismarck and Kaiser Wilhelm, accused him of planning a separate peace with Germany and attempted to transplant him into the latest iteration of a long line of German-descended Russian ministers whose times in office had coincided with Czarist tyranny and defeat in foreign wars such as Nesselrode, Osterman and Biron. ${ }^{183}$

The fact that there were so many German-named Russian officials to compare Sturmer with was illustrative. There was a certain cosmopolitan character to the Russian ruling class. Non-Russian sounding surnames were relatively common among the Czar's senior ministers and even his personal confidants - a Frederiks, a Witte or a Wrangel was as acceptable as a Korsakov, a Stolypin or a Protopopov. Many of the central institutions of the Imperial institution went by distinctly nonRussian names, such as the Imperial yacht Standart (Danish), the Imperial palace Oranienbaum (Swedish) or the Imperial Lieb Guard regiments (German). Baltic Germans in particular had played a disproportionately prominent role in Czarist political life since at least the Napoleonic wars and the highest offices of the Russian state had also frequently been open to those of other ethnicities one Imperial foreign minister, John Capodistria, was not only born in Greece, and of Greek descent, he later went on to become head of state of the newly independent Greek polity. What had previously been unproblematic now became intensely so, something that the commentary on Sturmer's surname illustrates. Sturmer, Rasputin and the Empress formed a triad of 'Germans' one by descent, one by behaviour, and one by birth.

183 Pares, Bernard, 'On The Appointment of Sturmer as Foreign Minister' in The Slavonic and East European Review, Vol 14, No 41 (Jan 1936), pp273-4. 


\section{Was Alexandra German?}

By the standards of a completist nationalist - that is, somebody who believed that, whatever the political situation, there always exists a group of nations whose existence is beyond question or obfuscation - Alexandra's status as a German was similarly beyond question. There is no other nation she could conceivably have been said to have been a member of. She was born in the town of Darmstadt, a city whose entire history had seen it inhabited by German-speaking people, and which lay at the physical heart of Europe's Germanophone territories. A visitor to the Darmstadt of Alexandra's youth would have seen traditional German dress, building styles and church services. In other words, there is little reason to doubt that the environment Alexandra was born in and raised in was anything other than German. It is true, the environment of the Grand Ducal Palace, where Alexandra and her siblings were instructed by cosmopolitan tutors, regularly visited and visited by their relatives from England, and learned languages other than German, was not quite as unambiguously steeped in the minutiae of German culture as the streets of the city beyond it, but to the completist nationalist these details do not negate her German nature. Alexandra was born in Germany, spoke German, practiced a German religion and lived in Germany for most of her formative years; ergo, case closed, she was German and would forever remain German.

This thesis no more purports to identify a 'true' national status for Alexandra than it does for Marie Antoinette. The temptation exists, as it existed for the Queen of France, to wonder how Alexandra regarded herself. A sufficiently large body of correspondence certainly exists that searching through it for nationalist self-descriptions might yield some interesting insight. But even if it were possible to divine with any accuracy the private thoughts of somebody who has been dead for nearly a century, it would not be helpful to this thesis. At the risk of repetition it needs to be stressed that we are interested, not in who Alexandra truly was, but in who she was perceived to be. 
The question then becomes whether the revolutionaries who overthrew the Czarina and her husband, and who used the presence of the Czarina at the supposed heart of wartime Czarist government as a way to de-nationalise and thus de-legitimise the government, were completist nationalists of the sort identified above.

The obvious alternative national identity for the Czarina was that she was Russian. Like Marie Antoinette, while she may not have been aiming herself at a consciously nationalist audience, the Czarina attempted to depict herself as belonging among the people of the state whose government she was connected to. One such attempt was her conversion to Orthodox Christianity, and her overt practice of the religion, frequently attending religious ceremonies, donating money to religious establishments, and so on. Alexandra's religiosity is the most evident sign of a conscious attempt to attain Russian national status on the Czarina's part and to answer the implicit case against her Russian-ness. Indeed, it could be argued that this was part of what drew the Imperial couple to Rasputin - a desire to establish a genuine, unmediated connect with the Russian people through the bridging mechanism of a deep, devout Christian faith. Rasputin represented an ersatz peasant - a stand-in for the Russian peasantry as a whole. This was a concept that Rasputin himself enthusiastically promoted. His allusions to a Russian state characterised by an unmediated union between the people and the Czar, was one such promotion of this. Another was his enthusiastic agreement with the idea that when they spoke to him, the Czar and Czarina spoke to the Russian people, and conversely that when he spoke to them he did so with the imputed authority of the Russian masses. ${ }^{184}$ Ironically Alexandra's association with Rasputin was as much a sign of her inability to understand the problematic nature of the Russian national ideal as it was her desire to connect with it. It is clear that Alexandra saw all narratives that saw Rasputin as inauthentically Russian in the ways described above as simply the product of personal malice. This in turn rendered her unable to understand how Rasputin made her unpopular.

$184 \quad$ Massie, p343 
This image could be said to amount to caricature or parody. Although Rasputin's biography was genuinely one that was a product of Russian peasant life, this does not mean that his enthusiastic promotion of it did not have an element of theatre to it. The fact that the Czarina was willing to accept interaction with Rasputin as a surrogate for interacting with the Russian nation suggests two

things. Alexandra felt that the measures she had attempted prior to Rasputin were insufficient. This perception may have arisen from an unrealistic expectation of her own ability to commune with the nation, to the point that she felt the need to make increasingly jarring attempts to achieve what was basically unachievable. This criticism was not one that Russian nationalists would make, as to admit that it was impossible for a ruler to rule nationally would be to undermine their ability to criticise rulers for failing to reach this communion. Accusing somebody of being unable to do the impossible does not create strong political claims. Simply saying that her efforts was insufficient was a way to square the presence of a figure who, whatever else might be said about him, clearly relied on no extra-Russian concepts for his political presentation of himself, as the closest confidant of the woman they wished to make Exhibit A for the anti-national character of the Czarist regime.

\section{The Image of Germany:}

It was significant that Alexandra and her political associates such as Sturmer were seen specifically as German, as opposed to simply generically non-Russian. The events of 1917 might have played out significantly differently if she had instead been French or English. Unlike France in 1792, which had two well established (if very different) traditional enemies of the polity in Austria and the United Kingdom, Russia had no 'old enemy'. In the period since the reign of Peter the Great Russia had fought the Ottoman Empire five times, the Poles three times, the French and Persians twice and Prussia, Japan and Britain once each. The Ottomans, however, could not fit the image of the traditional enemy that the Austrians did to French patriots in the 1790s. Both the Ottomans and 
Austrians were generally seen as being in a state of decline and prone to treachery and despotism. But by 1917 the Ottoman Empire had generally declined so much that it did not form a credible threat even when its inferior economic and military resources were allied to its (supposedly) prodigous disposition towards perfidy. Ironically its alien nature, both ethnically and religiously, to the various groups of Slavs who formed the conceptual heart of the Russian nation was too alien for it to act as the 'dark mirror' to France that Austria did.

Some of the same problems accrued to the candidacy of Poland as the historied enemy of the Russian Empire. The Poles were not as alien as the Ottomans - although practicing an alien religion and a foreign language, they were recognisably Slavic. ${ }^{185}$ But the fact that Poland was not an independent state but a territory divided between the Russian, Austrian and German Empires made a narrative that placed Poland and Poles in a position of permanent opposition to the Russian state's policies very problematic. First and foremost, giving Poland the status of 'public enemy number one' it would have meant openly endorsing the existence of the Polish nation, something with profound consequences for nationality policy in Russia's border areas. By the twentieth century the Russian state's policy towards Polish identity was one of almost totally unqualified hostility ${ }^{186}$. Obviously the concept of a national foe is not something that needs to intrude into official policy, since it is effectively a story rather than an application of state power (although it is a story about the application of state power, which is why the concepts are difficult to fully disentangle). It would nonetheless be theoretically possible to tell the story of Poland as Russia's nemesis while maintaining a stony indifference to any claims made in the name of Poland at the official level. But even if this dichotomy could be addressed on an ongoing basis it would not solve the problem that the Poles were not really a credible foe for the Russian state. Poles did not possess

\footnotetext{
185 The Slavic qualifications of Poles were so well established that it has been speculated one source of Russian AntiPolish sentiment stems from fears that Poles would displace Russians from their status as the 'leaders' of the PanSlav movement.

186 Weeks, pp54-9.
} 
a state of their own and were unable to challenge Russia on the battlefield, in competition for international trade, in the chanceries of third party states or in any of the other conventional arena in which a rivalry between two states could be played out. This is not to say that concepts of Poles as enemies did not exist. In Russian discussions of the appropriate nationality policy in the former Kingdom of Poland the vitriol used to describe Poles, particularly the Polish groups who would be the potential elites of any renewed Polish political entity, was quite similar to that used by French elites to describe their Austrian counterparts in the revolutionary period. ${ }^{187}$

The question of whether Poland fulfilled the same role for Russia as Austria did for France illustrates two crucial differences between France and Russia's conceptions of the tasks of the state, national or otherwise, at the outbreak of their revolutions. While France was outwardly oriented, Russia was inwardly oriented. The French state, despite the high levels of provincial identification and economic particularism, was basically homogenous and integrated. The Russian state was a diffuse mix of religious, linguistic and cultural communities. The primary high political tasks of the French state were external and were played out on a European canvas that abutted on the French state's territory but did not comprise it. Conversely, the very boundaries of the Russian state were highly contested and as such the high political tasks of Russia - the tasks on which its status as a great power depended, in other words - were oriented towards events and dynamics within its political borders. Often the orientation of Russian politics was entirely backward. A good example of this is the slavophile desire to annex Galicia from Austria. Rather than seeking the military glory or economic resources the conquest of Galicia would bring to the Russian state, slavophiles cherished the territory because it would allow Russia to more completely define the concept of Ukrainian national identity.

187 Weeks, pp31-3. 
Perhaps Russia's national enemy was Poland, perhaps it was the Ottoman Empire, or perhaps Russia shared the role between them. But the German state, which Russia found itself at war with in 1914, did not fill such a role for Russia. Russia had never been to war with Imperial Germany before, chiefly because Imperial Germany had only existed since 1870 . This did not make it a complete novelty. There were a plethora of potential predecessor states. Among such predecessors was the Kingdom of Prussia, which formed the actual core of the new German Reich, the amorphous Holy Roman Empire, from whom Wilhelmine Germany inherited its historical legitimacy and status as an Empire, and even the Teutonic Ordnungstaat, whose civilising and Europeanising mission in the east Wilhelmine Germany would eventually try to claim. But ironically this dearth of historical examples made it harder, not easier, for Russian policy-makers to contextualise the emergence of the German Empire. If post-1870 Germany was simply Prussia with some extra territories, it would no longer be a threat. If, alternatively, it was the Ordnungstaat with artillery and zeppelins, it was an extremely alarming development. The inconstant path of Russian diplomatic policy towards Imperial Germany in the years 1870-1914 was informed by uncertainty in Berlin and by basic incompetence in Russia, but this inability by Russian elites to find a place for Germany in their worldview also played its part. The emergence of a united Germany has often been called a diplomatic revolution in European power politics, and this was certainly the view from Moscow. To term it simply a diplomatic revolution understates the case. Germany's appearance not only challenged the power calculations made by realist actors. It placed a huge question mark over the concept of 'German' and further rendered removing that question mark a matter of pressing urgency to states, whereas previously it had been a question for intellectual cultural theorists.

There was much to recommend the idea of Germany as a larger Prussia. First and foremost there was formidable evidence of continuity at the high levels of the state. The King of Prussia became the German Emperor, and the Chancellor of Prussia became the Chancellor of Germany ${ }^{188}$

$\overline{188}$ Both, of course, retaining their prior Prussian offices. Observers who wished to find further evidence of the Prussia 
Although the militaries of the various German states remained separate, they were under Prussian command. The Prussian legal code became the basis for the Imperial legal code, often substantially displacing existing tradition. The Kulturkampf, a series of restrictions against the political activity of Catholic groups, was an expression of Prussian Protestantism. It was certainly possible to gather substantial evidence for the charge that Germany was simply Prussia under a new coat of paint. This interpretation offered little to alarm Russians, as there had been little tradition of conflict between Russia and Prussia. The two states had only fought once, during the Seven Years War of the eighteenth century, a conflict that both Russian and Prussian historians tended to interpret as an unpleasant and foolish mistake. But the main alternative hypothesis, that Prussia had been absorbed or even dissolved within a genuinely de novo German nation-state, was no more threatening. It was true that there was a certain suspicion of German culture, German mannerisms and general “German-ness' in Imperial Russia. This suspicion had a lengthy pedigree, going at least as far back as the $18^{\text {th }}$ century, when Lomonosov, the progenitor of Russia as a literary language, was motivated in part by competition with German-speaking colleagues in the Russian Academy of Sciences to construct a language he felt was equally able to confer complex concepts. ${ }^{189}$ But in Lomonosov's case, as more broadly, this 'German-ness' that attracted disapproval had little to do with attitudes towards the contemporary German Empire. As was the case with Lomonosov, when Russian nationalists spoke with disdain of Germans they were usually incorporating Germans seamlessly into a broader image of 'the west' without any particular regard for Germany as a discrete nation comparable to Russia on a bilateral basis.

That is not to say that Russian nationalists did not find the Wilhelmine Empire objectionable. But this distrust came from a perception that Germany was something new, not something as old as familiar Prussia, let alone the primordial German state. In an inversion to the manner in which

$=$ Germany theory could point to the fact that the offices of Prussian and German Chancellors were united for all but two years of the period between the Empire's establishment and fall.

189 Tolz, pp47-8. 
French nationalists in the late $18^{\text {th }}$ century despised Austria for its total failure to achieve anything even resembling a national life for its subjects, it was Germany's own status as a compact and homogenous state that aroused jealousy among Russian nationalists. These nationalists hoped that, by emulating Germany's neat correspondence between nation and state, they would be able to elevate Russia to the level of economic prosperity, military efficiency and diplomatic prestige enjoyed by the post-Bismarck Empire. Russia's officer corps saw in their German counterparts a model of the efficient, meritocratic and patriotic institution that they aspired to become. ${ }^{190}$ But the conception of Germany evidenced here was a fairly bland picture of an efficient, progressive western state that could easily have been (and to an extent was) applied to Britain or France equally well. Perhaps the main characteristic that the Russian military planners imputed to Germany beyond the generic Russian picture of Western states was that of national homogeneity. It was assumed that the German armed forces incarnated the German national principle on a mass level. It seems likely that the Russian officers, if so disposed to ponder the issue, would have agreed that this was true of the non-military institutions of the German state as a whole. This image of Germany presented a state Russia could aspire to emulate, not just in terms of technical accomplishment and organisation, but in terms of fulfilling the nationalist ideal of the nation and the state meeting up. This, as much as Germany technology or meticulousness, made Germany threatening as well as admirable - the nationalist equates nation-state correspondence with state effectiveness, and it is quite likely that the Russian military planners sought to imitate Germany in order to equip themselves with the weapons of their potential future enemy.

And they were right to do so. The likelihood of a Russo-German war grew greater and greater throughout the forty four years between Versailles and Sarajevo. The complexities of diplomatic history are not directly cogent to this chapter's argument, but it is worth noting that those who saw

90 Vitarbo, Gregory, 'Nationality Policy and the Russian Officer Corps' in Slavic Review, Vol 66, No 4, Winter 2007, pp683, 689, 694 . 
Germany as a threat to the Russian nation had substantial evidence on their side. In 1870 the state of Russo-German relations was generally very good; Bismarck placed a high priority on maintaining cordial contact with the Russian government, and was repaid by a level of trust among Russian policy makers that saw Russia accept attendance at the Berlin Conference of 1878 purely because the Germans were the hosts. Ironically the same Conference that owed its existence to Russo-German friendship marked the beginning of the decline in relations that saw the two powers drift slowly but irreversibly towards war, as Germany grew to prioritise Austria-Hungary as an ally over Russia, and Russian and Austrian interests increasingly clashed in the Balkans as both powers aspired to reap the lion's share of the benefits of the inevitable collapse of Ottoman Empire. This decline in relations can be mapped by the gradually more and more modest series of treaties that framed Russo-German relations. In 1873 the Three Emperor's League committed the two powers (along with Austria-Hungary) to mutual defense, albeit mostly against non-state revolutionaries rather than other states. After the Berlin Conference sabotaged the spirit of the League, Bismarck took care to maintain good bilateral relations with Russia by signing the Reinsurance Treaty of 1887, promising benevolent neutrality in the event of conflict. This was not renewed in 1890 . Although there was no formal, treaty-based relationship between the powers after this point they continued to cooperate, notably when Germany assisted Russia with logistics during its conflict with Japan in $1905^{191}$. But by 1914 Germany's formal relations with Russia were dictated only by the basic comity that was de facto for Great Powers, while Russia enjoyed a close and diplomatically codified relationship with France, a power that was intimately hostile to Germany. As such, there were good reasons to predict violence between the German and Russian states, based only on a review of their relative diplomatic positioning, without any need to resort to concepts of innate national antagonism.

191 Carr, William, A History of Germany 1815-1945, Edward Arnold, London, 1969, pp224-5. 
The outbreak of World War One required a redefinition and reprioritisation of Russia's relationship with Germany. When war was declared Russia shared lengthy borders with all three of the Central Powers - Germany, Austria-Hungary and the Ottoman Empire. From the outset it was Germany that inflicted the most telling defeats on Russian troops and Germany that penetrated the most effectively into Russian territory. In a perverse way, the relationship with Germany became Russia's most important foreign relationship. It was the actions of Germany, more than any other country, that would determine the future of the Russian state. This fact became more pronounced as the war progressed and the other Central Powers increasingly went on the defensive and became dependent on German assistance. While it is difficult to extract a clear vision of what it meant to be German in Russian eyes that is distinct from what it meant to be Western, after 1914 a rapid reimagining of German-ness became necessary and took place. A good example of this wartime reimagining can be found in writings on the subject of the 'spy mania' that gripped Russia during the early years of the war. ${ }^{192}$ One of the main activities of self-declaredly 'patriotic' media outlets and politicians was the exposure of 'Germans' within Russia. Although most such commentators saw the ubiquity of German personnel and capital in Russian economic life as some form of conspiracy it is more likely that it was the result of a sudden redefinition and expansion of the meaning of the term 'German' - where previously the managers, property owners and conveyancers whose presence was taken as so dangerous in the post-Sarajevo era had been characterised chiefly by their economic role, the outbreak of war meant that their nationality suddenly became the primary consideration. This phenomenon, of re-casting German individuals as dangerous foreigners, seems to indicate strongly that a similar re-imagination would have been undertaken with respect to the German state and the German nation.

192 Fuller, William C, The Foe Within: Fantasies of Treason and the end of Imperial Russia, Cornell University Press, Ithaca, 2006, pp180-2. 


\section{A foreign Czarina:}

The Czarina's status as a foreigner was actively harmful to her, and attempts to make herself more Russian such as her attempt to associate herself with the war effort or to connect with Rasputin substantially backfired. This was particularly true given her origin in Germany, a nation with a convoluted but always intensive relationship with Russian nationalists. It is notably difficult to extract any definitively, exclusively nationalist narrative from these criticisms. Attacks on the Czarina for colluding with Rasputin introduce notions of gender propriety and tyranny, as do her attempts to place herself in control of Russia's war effort. These continued conflations show strong evidence of a single narrative at work. 


\section{CHAPTER SIX:}

\section{FRANCE AND TYRANNY}

When the representatives of the estates general gathered in Versailles to begin the redefinition of the French state their goals were unclear and diverse. But if there was one principle that almost everybody involved in the revolution at any stage could support it was a principle of opposition to tyranny. Denunciations of tyrants formed both the mobilising agent of the conflicts the revolution found itself embroiled in and the glue which bound together the often diverse coalitions of actors who at various times kept the revolutionary process moving. This was no more neatly demonstrated by the fact that when a particular faction was expelled from the revolutionary project, usually with fatal consequences, it was accusations of tyranny that accompanied them in their fall. Danton and the Girondins, then Robespierre and the Jacobins, were all sent to the guillotine as tyrants. If they had been told that a future history of their revolution was to focus on their attitudes towards women or the nation, they would probably be surprised. But they would have been entirely comfortable to have their actions understood through the lens of tyranny for that is how they themselves understood them - or at least how they presented themselves as understanding them.

Whither tyranny?

What is tyranny? Or better still, why place an analysis of tyranny in the company of an analysis of nationalism and gender? The questions of 'what is the nation' and 'what is gender' are, as becomes evident even when only cursorily touched on as in this paper, the subject of a lengthy, broad and disparate discourse within the academic community but there is at least consensus that they are suitable subjects for intellectual analysis, even if there is no comparable consensus about the results of such analysis. But for many, the concept of tyranny is not even worthy of such analysis. Even 
those who do attempt such analysis often become frustrated by the lack of results their work provides. David Williams memorably characterised the concept of 'tyranny' as 'slippery', meaning less that it evaded definition than that it is so replete with definitions the task of attempting to harness one to any form of analysis, even a narrow one, can become frustratingly pointless. ${ }^{193}$ For this reason it is necessary to defend the decision to use tyranny as a term of analysis. In conceiving this chapter I considered other terms that might be more usefully applied in an attempt to translate the contemporary concern with 'tyranny' into a concept that carries more analytical weight. Ultimately however I came to reject these terms and felt that maintaining a focus on tyranny, while requiring justification, was preferable. The alternative terms, such as dictatorship or nondemocratic government, though clearer and more intellectually substantive, would risk inflicting an anachronism on the concept.

The term 'tyranny' begins with Plato and like many terms with classical antecedents quickly expanded so that little could be usefully said concerning it. But although the term may have little use to scholars, for active politicians it exercised a powerful attractiveness. In 1649 Charles I of England was executed for the exercise, according to his indictment, of wishing to rule through 'an unlimited and tyrannical power'. ${ }^{194}$ Although classical referents for tyranny remained popular throughout the revolution - St Just notably drew parallels between the death of Louis XVI and that of Caesar ${ }^{195}$ - they have little explanatory power. In general Greco-Roman 'tradition' served as a mask for genuine innovation in the same way ideas of ancient French liberties did. It is the intent of this piece to consider tyranny in the form it was understood during the periods concerned, and to regard other definitions as curiosities. A thoroughgoing analysis of the evolution of the concept over the two millennia of western political thought will not be found here. A definition of the term as it was used during the eras in question, though, will be useful.

\footnotetext{
193 Williams, David Lay, 'Modern theorist of tyranny? Lessons from Rousseau's system of Checks and Balances' in Polity, Vol 37, No 4, Oct 2005, p445.

194 Morril, John, The Nature of the English Revolution, Longman Group, Harlow, 1993, p287.

195 Blum, p176.
} 
First and foremost, and unsurprising, tyranny is universally understood as a negative concept. Plato organised government types into a hierarchy that was both chronological and value-laden and he identified tyranny as both the last and least worthwhile stage, and all subsequent thinkers have followed his lead. Even the most enthusiastic defenders of non-democratic, arbitrary government have not positioned themselves as defenders of 'tyranny'. Secondly, tyranny is usually a personal form of government. Once again, Plato provides the lead, identifying tyranny as the form of government determined by a single person, and whose flaws rest not on the shortcomings of a group or an ideology but rather on a single individual. There can be no tyranny without a tyrant. Other characteristics have been imputed to tyranny, and over the years the term has in general been reduced to a cipher for any form of government that the speaker does not support. But even such lax formulations essentially rest on the basic characteristics of the word as laid out by Plato personal, negative government - that can be usefully kept in mind as we move to a more specific examination of the concept as it was lived within the France of Marie Antoinette.

\section{Tyrants and the revolution:}

Tyranny as understood in the context of revolutionary and pre-revolutionary France derives largely from the writings of Jean-Jacques Rousseau. This may be seen as ironic, since Rousseau has been accused of being the "Greatest Muse of the Tyrants" by many scholars, most notably by Benjamin Constant, who identified his work as "supporting all kinds of Despotism"196. Whether or not Rousseau's conclusions can be used to support non-democratic government, Rousseau had a personal horror of tyranny and did not intend for his work to support it. When writing, Rousseau repeatedly set himself against tyranny and tended to use the term in a fashion consistent with that of classical philosophers, such as Plato. Indeed it would not be an exaggeration to say that the entire

196 Constant, Benjamin, 'Principles of Politics Applicable to All Representative Governments" in Political Writings, ed Biancamaria Fontana, Cambridge University Press, Cambridge, 1988, p177. 
body of Rousseau's political thought is an attempt to identify, eradicate and guard against the return of tyranny. ${ }^{197}$

Rousseau's clearest statement of tyranny has already been quoted in this work but it is worth briefly revisiting it. In chapter one it was proposed that Rousseau's explanation of tyranny, which in its totality encompassed both 'vulgar' and 'precise' forms of the concept, could effectively be collapsed into a single idea - that of government that disrespected the concept of law. To view tyranny as 'unlawful rule' is an attractive proposal, but there is a need at this stage, in pursuit of a more rigorous examination of the concept and its contemporary application, to reverse this collapse of diffuse concepts. While 'unlawful rule' is a very satisfactory theoretical explanation for what Rousseau and his fans among the French revolutionaries actually meant, there is a need in discourse analysis not to restrict oneself to the analytical heart of an issue but to pay attention to which of its subsidiary aspects are emphasised and which are allowed to lapse. In other words, it is significant that Rousseau chose to identify violence and illegitimacy as the main secondary characteristics of the politics of unlawfulness that lay at the heart of his explanation of tyranny, and it is even more informative that the revolutionaries who made him their intellectual mascot took this even further. ${ }^{198}$

It has already been noted in chapter two that despite the revolutionaries' enthusiastic claims to posit themselves as providing the practice to match Rousseau's theories, they were largely dishonest in doing so. But their attempt to appropriate the image of Rousseau as the heroic opponent of tyranny means that examining Rousseau's influence in the context of revolutionary conceptions of tyranny is more fertile than it is in contemporary conceptions of gender and nationalism, due to Rousseau's status as a revolutionary hero. Firstly it shows that Rousseau attained a celebrity status due to his image as an opponent of tyrants. Secondly it shows that the revolutionary authorities were sensitive

\footnotetext{
197 Williams, p447.

198 It is worth noting that Rousseau often uses the terms 'tyrant' and 'despot' interchangeably and his attempts to distinguish them are not coherent and quickly abandoned. Williams, p451.
} 
to the charge that they were the successors of the ancien regime's sins of unlawfulness in a way that they could not be seen as successors to its sins of femaleness or foreign-ness.

\section{Absolutism as tyranny:}

Other contemporary concepts of tyranny came, ironically, from the main potential source of tyranny itself - the monarchy, often even from the monarch himself. France was governed under a system known since the reign of Louis XVI as absolutism - a definition often associated with tyranny, but at the time seen as distinct from it. Louis XIV's 1667 declaration was effectively a refutation of the idea of tyranny.

Let it therefore not be said that the Sovereign is not subject to the Laws of his State, since the contrary proposition is a truth of the Right of Nations... more legitimate it is to say with the Wise Plato that the perfect felicity of a Kingdom is that a Prince be obeyed by his Subjects, that the Prince obey the Law, and that the Law be right and always directed to the public good. ${ }^{199}$

While this statement might be seen as a clear sign that tyranny was not synonymous with absolute monarchy, the truth is more complex. The very fact that the King, apropos of no particular development, felt the need to explain why he was not a tyrant implies that there was a reason to think he was. Furthermore, acknowledging that more than a hundred years later his great-greatgreat-grandson was attempting to make the same defense of himself against the same charges, we can conclude that there existed a permanent perception of tyranny in French absolutism.

199 Rousseau, p183. 
One important aspect of tyranny as understood by enlightenment thinkers is that it was inherently self-limiting or, to use the more moralistic language of the time, doomed to fail by its own flaws. This stands in stark contrast to absolutism's proud claim to conquer time in creating a system that would withstand all challenges. It is unlikely that many French thinkers drew this inference directly from Machiavelli's work, but their feelings are paralleled by his analysis of the 'Tyrant Prince'. This Prince, according to Machiavelli, would ultimately find that his contempt for law prevented him from maintaining himself in power. ${ }^{200}$ In other words, to identify a ruler or a particular practice as tyrannical was not simply an act of description or judgement, but also a warning and a prediction. This meant that, for all the negative moral implications and condemnation evident in a denunciation of a ruler as tyrannical, such a condemnation could also be seen as an invitation to change one's ways - despite the personal nature of tyranny, it was not seen as the case that any individual was doomed to be a tyrant based entirely on their personality traits. It was for this reason that even those who might be comfortable with government that was personal and indifferent, as absolutism was, would resist definitions of tyranny, as tyranny was temporary. Although writing well after the close of the enlightenment, de Toqueville embodied enlightenment ideas when he applied this pseudo-Machiavellian analysis to French absolutism. Toqueville's analysis of the ancien regime particularly pointed out that the sale of offices was not sustainable. ${ }^{201}$

Absolutism, with its focus on the personal role of the ruler, naturally led away from nationalist political ideals, which saw the appropriate focus as a national group that transcended any individual. There was a distinctly nationalist quality to commentary on tyranny that often led to an attack on a ruler for being tyrannical leading seamlessly into an attack on them for being foreign. Eighteenth century writers in both France and England, in commenting on the Ottoman Empire, particularly emphasised that a tyrant would characteristically surround himself with foreigners in order to make

\footnotetext{
200 Machiavelli, Nicolo, The Historical, Political and Diplomatic Writings of Nicolo Machiavelli, Vol 2, Christian Detmold trans, RJ Osgood \& Company, Boston, 1882, pp460-1.

201 De Tocqueville, pp132-3.
} 
himself impervious to the outrages of his own subjects in order to better ignore their interests. ${ }^{202}$ Indeed, the Ottoman Empire became something of a paradigmatic study for tyranny, and the idea that something Asiatic was being imported when government became despotic continued to resonate throughout the revolutionary era. While Machiavelli was more subtle in his attempts to place tyranny in opposition to nationalism, he emphasised the tyrant's indifference not just to explicit laws but to 'ancient customs' which are presumably inexplicit although nonetheless also widely understood. ${ }^{203}$ It was for this reason that Machiavelli's 'tyrant prince's reign was necessarily unsustainable and temporary, since the 'ancient customs' would prevail in the end. Machiavelli's customs are easy to reconcile with the nationalist concept of the true character of the nation and his belief that these customs will ultimately prevail over tyrants is similarly comforting to a nationalist who can be assured that the nation will endure in the end (particularly when contrasted with Machiavelli's predictable fatalism). Similarly, although the author did not frame them this way, de Tocqueville's description of inefficient absolutism can easily be appropriated to a criticism of venal government as unable to achieve the goals that are necessary for a nation to live out its destiny.

\section{The death of tyrants:}

So the consensus on tyranny in revolutionary France could be summed up thus; it existed, it was bad, the absolutist government was either an expression of it or was permanently liable towards it, it was foreign, it was tied to the personality of the monarch and it was a state of affairs that would inevitably end. Obviously any concept which carries as much moral weight as tyranny is hard to reconcile with a purely descriptive approach to politics. To be content with simply having identified tyranny as present but to do nothing about this state of affairs is unlikely. This analysis of tyranny's presence in France created a moral imperative to oppose it which was the basis both for

\footnotetext{
202 Cirakman, Ash, 'From Tyranny to Despotism: The Enlightenment's Unenlightened Image of the Turks' in International Journal of Middle Eastern Studies, Vol 33, No 1, Feb 2001, pp50, 53-4.

203 Machiavelli, pp460-4.
} 
legitimising and mobilising resistance. This matter needs to be stressed. It was tyranny, more than nationalism and certainly more than anger at femaleness, that proved the main public justification for the revolution throughout its stages. So what was the prescribed medicine for the sickness of tyranny in France - and what did it mean for the Queen?

The enduring image of the French revolution is the guillotine and the angry Parisian crowd. This was not the goal of the early revolution. The rapid transition from envisaging the monarchy as potentially reconcilable with the transition away from tyranny to viewing the death of the monarch and his spouse as a necessary prerequisite for eliminating tyranny from the body politic seems jarring. It is partly because of this transition that the guillotine has become so firmly engraved in the mental imagery associated with the revolution. The search for a permanent solution to tyranny, a way to ensure that France would never again be faced with the spectre of a government that disregarded the rights of its citizens or operated in secrecy, was the permanent preoccupation of revolutionary politicians, but the solutions they sought varied. In a sense their approach to the issue was pessimistic - despite their attempts to characterise tyrannical government as alien to the French people, with their attempts to associate it with foreign characteristics and practices (the Ottomans, the Austrians, etc) there was also a sense that tyranny, like a fire burning under ash, could spring back up unless comprehensively stamped out. Ironically many of the actions justified on this basis were of the sort that later lead the revolutionaries to be accused of a tyranny of their own. But such perceptions are usually based on a notion of tyranny broader than that held by the revolutionaries. It is true that during the Jacobin period the revolutionary government pursued a majoritarianism that verged on the totalitarian, to the point of equating a minority political position with treason. The revolutionaries saw no innate conflict between this and their self-regard as ramparts against tyranny. To them, tyranny meant disrespect for rights and secrecy. As long as their majoritarianism was open to the public - and it certainly was, with St Just welcoming armed members of the public into 
the galleries of the Convention even as it debated the King's death ${ }^{204}$ - and respected the rights of individuals who did not put themselves outside the body of the public through their actions - it was not tyranny.

But the fact that the revolutionaries saw no tyranny emanating from themselves did not mean that they did not fear tyranny's re-emergence on the political scene. If the tyrant was not eradicated, if even the slightest laxity or pity was allowed in the persecution of him, no outcome was too calamitous. Once again St Just summarised the concept well when he stated that the King "must reign or die". ${ }^{205}$ Susan Dunn has argued that during the debates on Louis XIV's fate the Jacobins effectively subscribed to the role of the King as a mythical figure with an ability to transform the French state that can only be described as supernatural. This was, ironically, entirely in keeping with the self-justificatory narrative of absolutism which arrogated to the King's person the ability to improve French governance. In claiming that the execution of the King would mark the true birth of the Republic the revolutionaries simply made the conceptually trivial alteration to the absolutist formula that the required action for the banishment of tyranny was Louis' death, rather than his benevolent rule. ${ }^{206}$ Speaking at the trial of Louis, St Just declared that 'That day will decide the fate of the Republic; its doom is fixed if the tyrant goes unpunished'. ${ }^{207}$

Although Dunn did not address the trial of Marie Antoinette when she spoke of the rhetoric that surrounded the trial and execution of Louis XVI it should come as no surprise that the same dynamics were at work. The revolutionaries tried to desacralise and de-monarchise Marie Antoinette, leaving only the 'Austrian woman' or 'the Widow Capet', but they could not do so in a satisfactory manner and felt the need to return to a formula that privileged her as a Queen. ${ }^{208}$ In

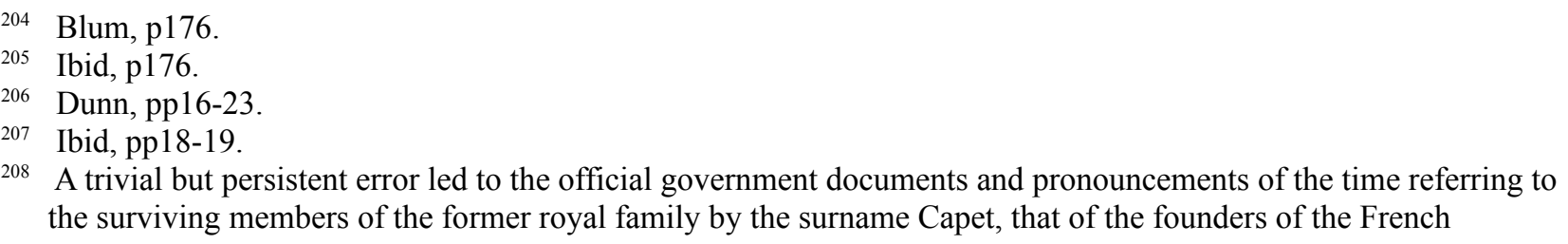


laying out the case for her execution, Hebert was reduced to returning to her royal status. 'Suppose, fuck it, that she wasn't guilty of these crimes: WAS SHE NOT QUEEN? That crime alone is sufficient cause to shorten her' ${ }^{209}$ Hebert effectively argues that it is impossible to treat Marie Antoinette as just another citoyenne; he cannot but see a Queen when he looks at her, and he effectively implores his readers to do likewise. Once Marie Antoinette had been so segregated from everyday life, her execution, like that of her husband's, became more than the routine carrying out of everyday law, and instead assumed a character of final benediction for the young Republic.

As a revealing postscript, the death of the accused tyrants, namely Louis and Marie Antoinette, did not mean that the guard against tyranny could be stood down. It was almost as if tyranny was a gothic, intangible, formless force that could shift effortlessly from one receptacle to another. When the King was dead, the Queen became the focus for fears of tyrants, and when the Queen died, tyrants began to appear among the ranks of those who had called for her execution. Maupeou was identified as 'the tyrant Maupeou', and as a 'despot' and a 'brigand' respectively, by Choiseul's supporters. ${ }^{210}$ At the same time that the presence of tyranny could, as we have seen above, be seen as an energising and legitimising force for the revolutionaries, it also presented a negative factor in their policy-making - it was an explanation for why their goals for improving the human condition, often messianic in scope, were not being achieved.

\section{Anti-tyrannical politics:}

The execution of the royal family was not the first solution offered to the problem of tyranny.

Indeed, it could be seen as an action of last resort. Earlier in the revolution, when the focus on ending tyranny was on reforming rather than overthrowing monarchical forms of government,

monarchy, despite the fact that their family was actually named Bourbon, a distant branch of the Capet house. Louis XVI was often referred to as 'Citoyen Capet' both before and after his death.

209 Colwill, p78. Emphasis is in the original.

210 Maza, p77. 
Marie Antoinette continued to play a part in the projected solution. This is probably more representative of general ideas of the Queen as tyrant than those that surrounded her trial were. When government was described as tyrannical the speaker was seen as offering the tyrannical ruler a way out of their own tyranny. It was as much an extension of assistance, in identifying problems and applying a remedy to them, as it was a condemnation. It has to be acknowledged that this idea of tyranny-as-prescription internally conflicts with the idea of tyranny as a product of the poor moral fibre of the ruler as a person, who presumably would be incapable of being elevated above tyranny even should he desire to be.

But the fairly blatant nature of this potential conflict demonstrates the difficulty of reconciling a quasi-popular narrative of tyranny with a concrete course of political action, a difficulty we can see in the political and programmatic confusion of the revolutionary period. Was tyranny something that exalted the ruler at the expense of his subjects, or was it a fool's path that resulted only in ruin for the tyrant as well as those he harmed? Could tyranny be resolved by appealing to the ruler's nobler instincts or his base desire for self-preservation? Could the ruler who ruled tyrannically be enlisted in the project to end his tyranny, or were tyrant and tyranny simultaneous? Was the existence of tyranny separate from the person of the ruler? These questions, when applied to concrete issues such as the constitution or the personal fate of Louis XVI and his family, are recognisably some of the main controversies of the revolutionaries and cannot be understood simply through seeing Louis' government as lacking in good governance. As any current development specialist will readily concede, probably with some frustration, the absence of good governance can be extremely resilient.

The hero who stands up to tyranny was an extremely powerful trope in pre-revolutionary France. This hero did not necessarily have to oppose the tyrant in the name of any great cause, not even one 
as reductive as simply reducing the level of tyranny - to advocate for one's own rights was seen as an activity worthy of public acclaim. This very much accorded with the liberal view that the rights of a people were nothing more than the sum of the rights of every individual. Therefore to know, describe, defend and profit from one's own rights was to achieve everything that could be expected of one in the public sphere. This was an essentially defensive construction which seemed to take the existence of tyranny as a given, rather like the existence of bad weather or earthquakes; the famous quote by Irish contemporary John Curran, regarding eternal vigilance as the price of liberty, is very much in this spirit.

This model of the anti-tyrannical hero has many exemplars in the period surrounding the revolution. Linguet, a publisher, was able to evoke a strong popular response by appealing to his own rights as a person in the face of what he saw as censorship of his writings. ${ }^{211}$ As already discussed, the popularity of Rousseau among revolutionary politicians owed more to his occupation of this memetic space. Voltaire's rapturous reception in Paris following his return from a semi-voluntary exile abroad was that of a conquering hero. What had he conquered? Tyranny. This is to say nothing of the various revolutionary politicians who phrased their arguments with their opponents as the struggle of the partisans of freedom and humanity against tyranny. Both Girondins and Jacobins were guilty of this. Robespierre equated the existence of an opposition party with 'despotism'. ${ }^{212}$ Prior to that Lasource, a Girondin leader, had denounced Robespierre's emergency measures as potentially leading towards the establishment of 'dictatorship'. ${ }^{213}$ Although the word 'tyranny' was not used the sense of an implacable tide of tyranny that could permit no opening lest France be swamped was very much intact in all these instances. To portray oneself as an activist against tyranny, even if one's activism was directed only at retaining one's own rights, was a fertile source of acclaim, legitimacy and even access to the levers of power.

211 Censer, Jack, 'France 1750-1789' in Burrows and Barker, pp175-7.

212 Sagan, p482.

213 Ibid, p110. 
Ironically when a leader was seen as a tyrant their refusal to tightly regulate all aspects of state life no longer counted against them. It could be assumed that when a ruler was not able to regulate or manipulate events that they presumably did not want to escape their control - and once the 'tyrant' label had been applied, all events fit this prescription - was seen, not of a sign of tyranny being reduced or mitigated, but of incompetence or inefficiency on the part of the tyrant. This happened on a prolonged scale throughout the late $18^{\text {th }}$ century when Louis XV and Louis XVI both failed to resolve the debate over Jansenism. ${ }^{214}$ Rather than welcome the monarch's leaving lower-level institutions to resolve the issue the failure to impose a solution was generally seen as a sign of incompetence. This was fair in some ways - in the past French monarchs had fought hard to establish their competency over ecclesiastical issues - but unfair in others - the conflict with the Jansenists was severely complicated by international political factors, notably relations with Rome.

Given that anti-tyrannical politics had become the only legitimate form of politics during the revolution, to the point that even actions that most would understand as meeting any reasonable definition of 'tyranny', e.g. the suppression of the expression of opposing viewpoints, were justified as being an antidote to tyranny, how were they practised? Was there a recognisable pattern of antityrannical politics? Robespierre, Lasource and their contemporaries described themselves as fighting against tyranny but did they go beyond simply calling themselves activists against tyranny or did they act in ways that were designed to appear to be contrary to the spirit of tyranny?

The politics of revolutionary France were, despite their practitioner's claims to have established and led a 'Republic of Virtue', no less responsive to personal corruption and ambition than those of the ancien regime which preceded them. However they were more than the triumph of personal ambition behind a facade of idealism. The practice of revolutionary politics was shaped by a distinct set of revolutionary values that were as much an attempt to chart a course opposite to the

214 Baker, Keith Michael, Inventing the French Revolution, Cambridge University Press, Cambridge, 1990, pp168-9. 
ancien regime as they understood it. In the same way that the revolutionaries attempted to negate the feminine and non-national features of the monarchy by imposing a new gender and national framework on France, they tried to create a set of political practices, be they customs, laws or simply strong public expectations, that would be the negation of the tyranny they had removed.

The conduct of political business in the public eye was probably the most obvious and universal value of revolutionary politics. While public spectacle was not foreign to the ancien regime, it had been a closed, insular political world. The removal of the royal family from Versailles to Paris had, as has been mentioned already, been seen as bringing them to a location more in accord with the traditional institutions of French government, but it was also an immersion in a very physical sense in the ordinary citizens, whose ability to perceive and comment on the doings of the court was seen as a definite good. This may be why guarantees given to the King, even when he was a legitimate constitutional monarch, concerning his personal safety (let alone his property) were never taken very seriously by the revolutionary government, even the moderates. By placing the royal court in Paris they were effectively calling on the Parisian public to interact with and if necessary harshly judge the royal family, so that, when that judgement became so harsh as to prompt physical violence, they felt unable to strongly condemn, let alone oppose it. More broadly, when not dealing directly with the royal family but simply conducting the positive business of the new regime, the doors of state business were open to the public eye. Indeed, the valorisation of the concept of 'public opinion' and the increasing levels of sophistication imputed to it were one of the main precursors for revolutionary ideology and was even briefly integrated into the practices of the monarchy when Necker published the state finances for the first time. ${ }^{215}$

\footnotetext{
215 Baker, pp185-92. The fact that Necker's publication was very far from an actually comprehensive overview of the finances of the French state neatly, if somewhat perversely, proves the point. So strong was the legitimising factor of publicity that people were more enthused by the act of publication than what was published; Necker's act could be seen as the first act of political 'transparency theatre'.
} 
The exercise of judicial mercy was another way that the new, revolutionary state tried to establish its anti-tyrannical credentials. Although the central figure that leaps to mind when considering revolutionary justice is, of course, the guillotine, the picture was significantly more complicated than that of the bloodstained cobblestones and the tricoteuses, who owe their memetic endurance at least partly to the strident moral outrage of anti-revolutionary emigre agitators. Indeed it is worth noting that even the infamous guillotine was introduced as a humanitarian alternative to the ancien regime's preferred methods of execution, and it must be admitted, when comparing the death of Louis XVI - for all else that might be said about it, mercifully quick - and that meted out to Robert Damiens, the attempted assassin of his grandfather, who was drawn and quartered.

\section{The fate of the tyrants:}

Since tyranny is inextricably bound to the person of the tyrant, the best way to practice antityrannical politics is to set oneself in opposition to the tyrant himself. At first this form of personal anti-tyranny seemed to be absent from the revolution. Many of the reforms initially demanded by representatives to the Estates General would have strengthened the power of the monarch within the state. ${ }^{216}$ This abstract view of tyranny as something that was endemic to the system, despite being rather strongly opposed to both the popular and Rousseau-derived concepts of tyranny, remained pervasive and was presumably one of the reasons that the revolutionaries initially intended to retain Louis XVI in his personal position, even with substantial privileges putting him substantially above the law - the King, for instance, could not be tried, merely deposed. Even at this point no privileges were granted to the Queen, whose relationship with the head of state was seen as merely private and neither requiring nor justifying any sanction by the state. This approach to the Queen's legal status provided a convenient resolution to the paradox of anti-tyrannical politics at this stage of the

\footnotetext{
216 Blackman, Robert H, 'Representation without Revolution: Political Representation as defined in the general
} Cahiers de Doleances of 1789', French History, Vol 15, No 2, 2001, p162. 
revolution - it allowed the revolutionaries to elevate the King as a bulwark against tyranny while allowing the continuing suspicions concerning his personal relationships and their consequences for the state to remain unaddressed. This is particularly true if we assume that at least some of those who rejected any constitutional status for the Queen did so because they contemplated some form of legal action - exile, divorce, private litigation or even execution - against her once the legal situation had been allowed to bed in.

Robespierre, contemplating the execution of Louis XVI, extraordinarily stated that the true sacrifice was not the King's life but his own pity, lost when he suppressed his natural human tendency to extend compassion to somebody powerless in the face of death. ${ }^{217}$ Even though earlier statements by other Jacobins seemed to contradict the idea that the King was powerless, Robespierre admitted that he was, better to draw attention to his own wrenching need to deny the basic humanity in himself and better draw attention to his sacrifice in order to end tyranny. The irony of the idea that tyranny, characterised as we have seen by bitter indifference to the suffering of those who find themselves beneath it, is best obviated by cultivating a similar indifference, is hard to pass over but it has been extensively commented on and is not germane to the argument being developed within this piece. What is of interest is the fact that the tyrant has put himself outside the bounds of humanity since compassion for one's fellow humans was frequently advocated as the central principle of the revolution. ${ }^{218}$ There was literally nothing that could not be justified in pursuit of a tyrant, and even if Robespierre did not go so far as to say that tyranny in persecution of tyrants was justified, his willingness to abandon revolutionary ideology in the face of tyranny is effectively an even more heartfelt commitment to anti-tyrannical politics. This same principle was applied to Marie Antoinette, who was seen as so great a tyrant that no restraint was necessary in dealing with her. Hebert stated that she should be 'chopped up like pate for all the bloodshed she has caused'. ${ }^{219}$

\footnotetext{
217 Dunn, pp20-1.

218 Blum, p178.

219 Sagan, p349.
} 


\section{The true tyrant:}

This idea of tyranny as emanating from sources other than the tyrant and his immediate entourage had many manifestations. Foreign armies were seen as carrying tyranny in their knapsacks. This is another occasion where fear of the form of government that constitutes tyranny coincides with fear of intervention within the national unit by foreign groups. In 1791, following the Flight to Varennes, persistent rumours of invasions by foreign soldiers imitated the earlier stories, known to history as 'The Great Fear', concerning brigands doing effectively the same thing ${ }^{220}$. Notably in the latter case the source of the rumours appears to have been the capture of the royal family in Varennes after their unsuccessful attempt to leave the country. It is notable that the fears of tyrannical oppression - namely the expected outbreak of violence and suffering - assumed a national character when the royal family was involved, while during The Fear they had a more generic character, with the imagined antagonists being brigands rather than foreign troops. But the event had equal implications for fears of tyranny that were without any national flavour. The flight left a bitter aftertaste of heightened belief in the existence of counter-revolutionary conspiracies that persisted well into the Napoleonic era.

One study showed that communities situated near forests were more likely to exaggerate and embellish with gothic detail news reports. ${ }^{221}$ While it is possible that the economic characteristics of communities largely oriented towards the forestry industry might explain this, it is also tempting to contemplate Braudel's idea that it rose from a particular mental state originating from proximity to the forest. Braudel argued that forests were considered dangerous, unpredictable and ungovernable and that those living near them were inclined to view the world as a whole as forestlike. ${ }^{222}$ This collision of a very pre-modern sense of the world as a violent place unresponsive to

\footnotetext{
220 Tackett, p150.

221 Ibid, p164.

222 Braudel, L'identite de France in Tackett, p164.
} 
human needs with a modernist one produced a productive result. Tyranny in a sense elevated the aesthetic of the forest to the milieu of the chancery and the court. The two conceptions arose from very different causes and travelled in very different directions but the fact that when they collided they reinforced one another is very revealing.

In a way this belief in tyrannical conspiracy briefly helped to protect the King as an individual. If, as those who saw the absolutist monarchy as a system of tyrannical conspiracy contended, nothing in monarchical government was ever as it seemed, it was obvious that he who claimed to hold the central role could not actually do so. Somebody had to be pulling Louis' strings and substituting their interests for his own. Despite being rooted in a contention of complexity this narrative still had more explanatory and emotive power if it was rendered as simple as possible, and this simplicity required a single string-puller rather than a group or a faction (let alone an economic class or interest group). The single most credible figure was Marie Antoinette for the simple reason that she, unlike the various other courtiers and ministers who had found their way in and out of the King's confidences, had been a constant figure, enjoying an enduring formal connection to Louis even if her actual prominence and power had waxed and waned. ${ }^{223}$ When this was combined with her status as a woman and a foreigner, outside the homosocial fraternity that was the French nation in the public sphere, she made the ideal candidate. This explains why, even with a government uninterested in placing the blame for Varennes at the feet of the Queen, she quickly found herself considered solely responsible for the course of events, with other actors, such as the King of Sweden, the Emperor or Count Fersen, having their roles in the story outlined chiefly as ways to further allude to her guilt rather than offer alternative or even supplementary 'culprits'.

\footnotetext{
${ }^{223}$ It is possible that Louis' brothers, similarly constant, might have played a similar role, and they were often coimplicated with Marie Antoinette, particularly the Comte D'Artois. However by the time of the flight to Varennes both had fled the country and were thus both literally and figuratively unavailable to take the blame.
} 
There are two main components to the charge that Marie Antoinette was a tyrant. The first and more forceful charge was that she had power over certain aspects of the French state's administration and that she exercised this power in tyrannical ways. The second, less immediately forceful but harder to disprove charge is that she did not personally exercise power over the state herself but that she caused her husband to act in such a way. Often one charge fades very rapidly into another and not all of the Queen's detractors took a firm stand on one or other side of this distinction. This is to be expected, as there is nothing implausible about the idea that she did both. However, each narrative creates a different picture of Marie Antoinette's tyranny and as such they provide a useful way to segregate opinions concerning her role.

The first narrative is one which superficially seems easy to refute. Despite the contentious nature of the French Constitution it was clear that the Queen had no power Probably the best illustration of this is the few occasions in French history when a Queen was granted power outside of that relevant to her status as consort, usually as regent for an underage son. A claim in the name of the King's wife had far less legitimacy than a claim in the name of the King's mother. It cannot be denied, however, that Marie Antoinette was able to wield power over several important functions of government. Early during her reign three of her husband's more powerful ministers regarded her as their patron - the Marquis de Castries at the Naval Ministry, the Marquis de Segur at the War Ministry, and Baron de Breteuil, the Royal Household Minister who had previously been an ambassador in Vienna. ${ }^{24}$ In her letters to her daughter Maria Theresa constantly encouraged Marie Antoinette to exert influence over the French state, an exhortation that, while it might have been unreasonable in its assessment of Marie Antoinette's own character, seems to suggest that broadly speaking it was not unlikely that a Queen could get things done if she applied herself with discernment and energy. But even considering the power Marie Antoinette was able to wield we are

\footnotetext{
224 Hardman, John, 'Decision-Making' in The Origins of the French revolution, Peter Campbell ed, Palgrave
} MacMillan, Basingstoke, 2006, pp67-8. 
forced to concede that it was a highly qualified, indirect power, and that she rarely had the final say on any matter of political consequence. When her chosen outcome occurred, for instance in the case of the aforementioned ministerial appointments, it was not solely because she wished for the person in question to be appointed but because she was able to work with others who had the same goal. This is not to downplay her ability to shape events, but it has to be acknowledged this practise fell well short of the tyrannical image that the revolutionaries played against. Such coalitionbuilding was definitely rational political behaviour in the context of courtly politics but it was not the image of arbitrary, unresponsive rule that was needed to justify a revolutionary upheaval.

It is the second image, the image of a Queen who might not have directly practiced arbitrary, selfish government but who induced and rewarded others such as her husband or his ministers to practice it, that provides the bulk of the actual references for accusations of Marie Antoinette as a tyrant. When revolutionaries accused the Queen of subtly urging her husband towards tyrannical, or for that matter anti-national policies, they accused her twice - once of promoting a harmful or incorrect policy, and once of using a mode of promoting it that was in itself illegitimate and damaging. If we are to take these revolutionaries at their word they would presumably have taken the time to attack Marie Antoinette for her methods even if these methods had been used for neutral or even positive ends. Blurring the boundary between gender and tyranny, this allegation can be understood as a specifically feminine mode of power, due to its correspondence with what were seen as typically feminine traits such as privacy, indirectness and reliance on informal bonds. But it is no less a tyrannical form of power for its femaleness. When Machiavelli spoke of the tyrant's disdain for the law he created an image of tyrannical power as acting outside the constraints or legitimacies of formal legal obligations that fitted well with Marie-Antoinette's refusal to occupy her legally designated role of politically null spouse to the head of state. 
Lynn Hunt summarises much of this concept of indirect tyrannical power when she explains that the Queen was attacked for her dissimulation: her ability to present a public face that was at odds with her private ambitions. ${ }^{225}$ The revolutionary ideal was one of total, absolute honesty, of exact correspondence between public and private, for the valorisation of the former. Dissimulation was the nullification of the spirit of public incarnation that the revolutionary state required in order to survive. Perhaps, in her incarnation as la veuve Capet in particular, Marie Antoinette could be forgiven for dissimulating herself, as she was only one among millions of citizens and the revolution's success no more depended on her than any other. But even if she could have been reduced to this, the newly-minted Citizeness was more than simply a dissimulator - she was an exporter of and mentor in dissimulation. Marie Antoinette was accused of teaching her husband, her son and her other intimates to dissimulate. In doing so she stood as exemplar and proxy for generations of women who were accused of teaching men how to dissimulate, something that was felt to be foreign to their nature, and in doing so creating an environment where dissimulation, and the attendant climate of policy-making that was private and indirect, were the dominant feature of the political system. ${ }^{226}$ In this sense, her execution treated the actual disease, while Louis' treated only its most irksome and prominent symptom. With Louis gone the disease could stop advancing, but only once Marie Antoinette was similarly executed could its spread be reversed.

The role of tyrants in the revolution:

Comparatively little space has been dedicated to the specific actions of Marie Antoinette, or even of specific narratives concerning her. She certainly looms less large as a person than her counterpart does in a corresponding study of tyranny in revolutionary Russia, as we shall see. This is partly because the more sophisticated nature of political philosophy in late $18^{\text {th }}$ century France than in

\footnotetext{
225 Hunt, Lyn, 'The Many Bodies of Marie Antoinette' in The French Revolution: Recent Debates \& New Controversies, Gary Kates ed, Routledge, New York, 1998, p283.

226 Hunt, 'The Many Bodies of Marie Antoinette', p284.
} 
early $20^{\text {th }}$ century Russia requires a more thoroughgoing analysis of exactly what was meant by tyranny if strong explanatory claims are to depend on the concept. In Russia, less explanation is needed and more attention can be given to specific instances of perceived individual misbehaviour. But the role of Marie Antoinette as not simply $a$ tyrant but potentially the tyrant, and the source of the omnipresent tyranny that so agitated revolutionaries, cannot be overstressed. It is also notable how often concerns of nationalism, as with oriental images of tyranny, or gender, as with the charge of dissimulation, creep into a discourse that tries to establish a strong theory of tyranny. This conflation is consistent with what we have already seen in discussions of gender and nationalism, and will be returned to in our conclusion. 


\section{CHAPTER SEVEN:}

\section{RUSSIA AND TYRANNY}

Tyranny is largely an aspect of governance, and two concepts loom large in any discussion of governance in pre-revolutionary Russia: autocracy and conspiracy. Autocracy was an idea that was found everywhere by those who cared to make even a cursory review of Russia's politics - it began with the Czar's official title of 'Autocrat' and recurred throughout the governing structure.

Conspiracy was obviously not alluded to officially, but the existence of conspiratorial factors within government was something widely accepted at all levels of society, from peasants suspecting their superiors of grain hoarding, to the Czar's concerns about disloyalty among his ministers. Even foreign observers bought into conspiratorial narratives, with stories of sinister machinations often finding their way into ambassadorial dispatches. ${ }^{227}$ Disagreements between liberals and conservatives, or between revolutionaries and supporters of the regime, were not about whether there were conspiracies or how severe they were, but simply in which cause conspiracy was being employed. Autocracy belonged to the official pronunciations of politicians and nobility. Conspiracy belonged to the chatter of boudoirs and salons. Despite this, the two are linked. Indeed, it could be argued that they are the same thing, that conspiracy represents a popular attempt to understand autocracy. This is a misrepresentation, for it fails to address the fact that many saw autocracy as the solution to conspiracy.

The concept of tyranny was not foreign to the political classes of late Czarist Russia, whether they saw its image in contemporary governmental practices or simply as a hypothetical image of what an illegitimate government would be. Therefore it is productive, if slightly anachronistic, to speak of the tyranny in Russia. This anachronism can be addressed by careful attention to the rhetorical

\footnotetext{
$\overline{227}$ Figes and Kolonitskii, p17.
} 
elusions of contemporary actors. One phrase that immediately registers after such an examination is temnye sily, or 'Dark Forces'. This phrase appeared as a way to identify the enemy in revolutionary folk songs, and as the title of a pornographic movie castigating Rasputin and the Czarina. ${ }^{228}$ When Vladimir Andronnikov, an associate of disgraced War Minister Sukhomlinov, appeared before a tribunal he defended himself by stating that he was 'not a dark force'. ${ }^{229}$

Semantically this term is vague and taken purely descriptively it has no real meaning, as any group that the speaker disapproves of could potentially be seen as 'dark' and a 'force'. Its use had deep roots in peasant discourses but these erupted into educated official society during the last years of the pre-revolutionary period and had connotations of unseen affects that were harmful to the public interest. $^{230}$

The notion of conspiracy also had deep roots in Russian culture. Access to power in Russia had often been historically distributed as much by assassinations, espionage and bribery as it had by law or tradition. The notion that 'true' policies or 'true' government were being obscured was something that the Russian peasantry were extremely receptive to. The Bedzina peasant uprising relied on the idea that the true Czar was being concealed by the nobility and making his will known to the peasants through a code. ${ }^{231}$ In 1861 , former serfs' dissatisfaction at the terms of their emancipation was propagated through stories of a 'true' emancipation code that was being hidden by the nobility. ${ }^{232}$ The belief in conspiracy did not need to depend on such stories. The all too real existence and public operations of the anti-Czarist Decembrist conspiracy in the 1820s, or the role of groups of revolutionaries with conspiratorial aims in assassinating public figures such as Czar Alexander or prime minister Stolypin, only validated broader conspiratorial narratives. Even Lenin's theory of

\footnotetext{
228 Figes and Kolonitskii, pp14, 111.

229 Fuller, p109.

${ }^{230}$ Figes and Kolonitskii, p27.

231 Paperno, Irina, 'The Liberation of the Serfs as a Cultural Symbol' in Russian Review, Vol 50, No 4, Oct 1991. pp427-8.

232 Christian, David, Imperial and Soviet Russia: Power, Privilege and the Challenge of Modernity, Macmillan, Hong Kong, 1997, p90.
} 
the revolutionary vanguard is capable of being seen as an apology for the idea of government by conspiracy on Marxist terms.

Outside the centre of this conspiratorial, autocratic government, but intimately connected to it through sexual and dynastic bonds, sat the Czarina. Like Marie Antoinette, Alexandra was seen by many as not just an adjunct to the personal tyranny of the monarch, but as more tyrannical than her husband, and even responsible for his tyrannical practices. The case for the figurative prosecution is made in characteristic fashion by Ivan Bydzan, a Socialist Revolutionary politician writing in a foreword to a collection of the Czar's personal correspondence. He identifies the Czarina as "an unbalanced woman with a strong determination to protect the prerogatives of an "infallible" autocracy and a penchant for adventures into arcanum" whose husband "bowed to her wishes, sometimes protesting feebly for a time, but almost always yielding in the end". ${ }^{233}$ This view transcended political ideology and was shared by those who differed from Bydzan politically.

Whether the Alexandra-Rasputin duad was actually in control of the Russian state, and thus responsible for any of the abuses that occurred during the reign of Nicholas II is no more relevant than the degree to which Marie Antoinette had supposed control of France. It is clear, however, that the idea that they did exercise a high degree of control, either in the absence of or the abject negation of her husband's attempts to exercise his powers, was one that had an extremely potent currency among the groups who eventually came to overthrow the monarchy and restructure the Russian state. Felix Yusupov, the Czar's cousin and one of Rasputin's eventual murderers, claimed of the starets that 'by his abominable deceit he has made the Russian Throne his fortress'. ${ }^{234}$ The tyranny of the Czarina was an important factor in the 'brief' held against her by oppositional forces in pre-revolutionary Russia, and needs to be examined independently of concerns for her nationality

\footnotetext{
233 Bydzan, Ivan, 'Foreword' in The Letters of the Tsar to the Tsaritsa, A.L. Hynes trans, Hoover Institution Press, Stanford, 1973, pp ix-x.

234 Youssoupoff (sic) Felix, Rasputin, Johnathan Cape, London, 1927, p73.
} 
and gender although, as has been anticipated, it will be shown that it is often impossible to extricate the three stories from one another. In this case the story is one of a death by a thousand cuts multiple petty acts of selfishness, capriciousness and illegality slowly accumulated a greater and greater burden on the backs of the suffering Russian people. But two such acts stood out as establishing the Czarina as a practitioner of tyranny. The first was the assumption of supreme command of the armed forces by the Czar. The second was the appointment of Boris Sturmer as prime minister.

\section{The Absent Czar:}

Before 1915 the position of Commander-in-Chief had been occupied by Grand Duke Nicolai Romanov, the Czar's cousin. ${ }^{235}$ The Grand Duke was a career military man who was generally viewed by the opposition as one of their own. Although the idea that the Grand Duke was a liberal contained elements of wishful thinking, it was not entirely without foundation. In 1905 the Grand Duke, as military governor of St. Petersburg, had strongly advised his cousin against attempting to suppress revolutionary unrest with force, ${ }^{236}$ and in 1917 he would equally strongly advise the Czar to abdicate. ${ }^{237}$ Due to the high priority given to the armed forces during wartime the Grand Duke had the potential to usurp the other organs of government and become in effect a second Czar. Either ignorant or disinterested in this potential, the Grand Duke made few efforts to obtain any non-military responsibility. He was not a very talented military commander, going so far as to absent himself from command conferences so that his subordinates would not be able to complain of him 'getting in their way'. ${ }^{238}$ Although the Czar's opponents viewed the Grand Duke as an atavistic incarnation of the educated, patriotic Russian struggling against unknown 'dark forces' and

\footnotetext{
235 Within their family the Grand Duke, who stood six foot six inches tall, was known as 'Big Nicky' to distinguish him from his more physically slight cousin.

${ }_{236}$ Verner, Andrew M, The Crisis of Russian Autocracy, Princeton University Press, Princeton, 1990, p235.

237 Figes, p340.

238 Ibid, p259.
} 
motivated only by duty, there is little to suggest that the Czar himself saw the Grand Duke as a rival, let alone an enemy. Nonetheless, by 1915 he became convinced that he needed to assume the position of commander-in-chief himself, displacing the Grand Duke, who was given command of Russian forces in the Caucasus.

The decision was heavily criticised almost unanimously by the Czar's ministers and other commentators. In the Duma liberals warned the Czar against making the journey to Mogilev. Despite this, it is not difficult to imagine a perspective that would view the idea as having merit. In replacing the Grand Duke, it might hypothetically be argued, the Czar was investing himself more closely in the war. He was physically removing himself from the company of the courtiers of Tsarskoye Selo to the officers and soldiers of Mogilev, and institutionally placing himself at the head of the armed forces. This seemed to be a step to mitigate, if not entirely solve, the problem identified by liberals of the Czarist government's refusal to engage itself fully with popular forces eagerly offering their support for the war effort. Certainly, according to the Czar's own letters, the impulse that drove him was that he wished to be of service, and avoid the perception that he was not personally invested in the military's successes or failures. Although personally comfortable among military people, the Czar does not appear to have had any delusions towards military talent. He notably never granted himself any rank above that of Colonel, and when choosing his Chief of Staff, eventually settled on General Alexeev, a General notable for a high level of command competence. Nicholas was aware that this individual would be exercising the actual functions of the Commander-in-Chief, while his own role would be chiefly symbolic. It can only be concluded that the Czar's decision to appoint himself commander-in-chief was aimed at countering allegations of tyranny. 
Unfortunately, whatever motivations lay behind the decision of the Czar to go to Mogilev, or the motivations of his ministers and critics for opposing this decision, the action had little tangible benefit for the war effort and actually seems to have been harmful. The Czar's absence from the 'rear' led to a significant decline in administrative efficiency, while his presence at the front did nothing to appreciably raise the morale of the soldiers. ${ }^{239}$ The Czar's actions demonstrated he had nothing to offer the military. They also revealed that his engagement with the civilian state, while little acclaimed at the time, had apparently had a positive benefit after all. Although in theory the Czar was able to fulfill the functions of the head of state at a distance from Mogilev - and it is worth noting that his habitual residence in Tsarskoye Selo did not necessarily place him physically at the heart of matters - in practice he delegated many of the functions of the head of state to the Czarina in his absence. This was certainly the view of the opposition, who often claimed that the Czarina, and through her Rasputin, ruled in his absence.

It soon became the popularly accepted story that the Czarina and Rasputin had actively encouraged the Czar to go to Mogilev. Yusupov identified Rasputin's collusion in the Czar's departure as one of the staret's most damning crimes. ${ }^{240}$ The physical absence of the Czar was an easy way to create a picture of poor governance. The Czarina and Rasputin would be free of the Czar's gaze to collude in corruption, caprice and cruelty. To many observers, such as Bryzdan, the physical removal of the Czar to Mogilev coincided with the collapse of government and its replacement by conspiracy and illegality - in other words, into tyranny.

\section{The Sturmer Ministry:}

The appointment of Boris Sturmer as prime minister ${ }^{241}$ was seen by many as the culmination of the

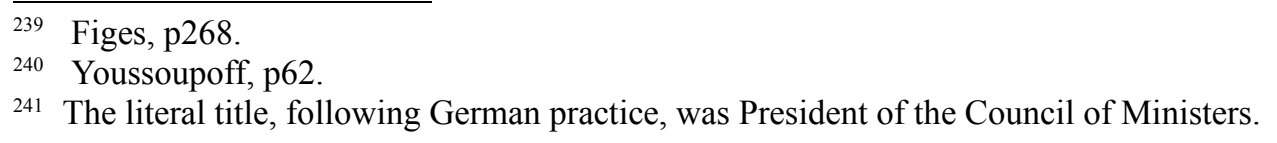


influence of the Czarina and her allies in government. We have already described the perception of Sturmer as a traitor to the Russian nation, but his unpopularity also had a significant non-national dimension which is best explained in terms of tyranny. To give even a representative list of the criticisms made of Sturmer during his brief but eventful term as prime minister would be excessive, but it is indicative that even the Czar, admitted that "nobody believes in him and everyone is angry because we stand up for him". ${ }^{242}$ This unpopularity was partly reductive - Sturmer had come to power with the active, illegitimate approval of the Czarina, so he must have also been illegitimate. But the disdain Sturmer faced, both among his contemporaries and, it must be said, among historians, seems based on the idea that he was unsuited for the prime minister's office and would function there chiefly as a cipher through which the desires of the Czarina and Rasputin could be enacted. It is certainly true that, when the biographies of Russia's Premiers in the twentieth century are laid out, Sturmer's seems particularly thin. Prior to his appointment he had served as the Governor of Yaroslavl province and as a Department Head in the Interior Ministry. His four predecessors as prime minister - Goremykin, Kokovstov, Stolypin and Witte - had all served as either Interior or Finance Ministers before becoming prime minister. ${ }^{243}$ There was nothing on Sturmer's curriculum vitae that would seem to indicate he was a potential candidate for the prime minister's office. Although it would be a mistake to claim that this proves that Sturmer was an inactive cipher, the violation of what seemed to be a fairly strict preference on Nicholas' part for men with substantial experience in high-ranking ministerial posts seemed to demand some form of explanation, and attributing this discontinuity to the malevolent influence of the Czarina was just as credible to some form of wartime expediency.

\footnotetext{
242 Hynes, pp256-7.

243 Prior to Witte and the 1905 reforms that created the Duma and moved towards responsible government, the office of prime minister was substantially different. Several of the pre-1905 Premiers did have quite thin curriculum vitae, but this did not work towards Sturmer's favour, since few of the Czar's critics were interested in returning to a pre1905 idea of the Premiership.
} 
The disdain for Sturmer was pervasive. His Interior Minister, Protopopov, was equally hated, and was also seen as excessively close to Rasputin and the Czarina. Even when individual ministers were not a target of criticisms, the sense of ministerial chaos that accompanied Sturmer's tenure furthered the perception of tyranny, as it created the impression of arbitrary and capricious government. There was a very high turnover of Ministers during Sturmer's period as prime minister, and while ministerial appointments and resignations always met the (minimal) standards of legality and propriety the cumulative impression was not of efficiency. This ministerial roulette was attributed to the Czarina-Rasputin duad. Despite seeing a cabinet responsible to them as one of the main goals of their plans for democratising Russia, Duma members viewed the departure of a minister for inability to work with them as a sign of government weakness.

This perception of the Sturmer ministry as an engine of private pecuniary advantage and criminal subterfuge was only the culmination of a long tradition of suspicion of bureaucratic mechanisms of government in Imperial Russia which had expanded under Nicholas II. Although stigmatised by other Europeans as backward and poorly governed, Russia did possess a functioning education system and a formidable bureaucracy whose presence in all areas of administration remained a constant up to, and throughout, the February and October Revolutions. Like many bureaucracies, Russia's attracted little support from those outside its ranks. Hatred of the bureaucracy was an almost universal theme among Russian political activists and thinkers. Conservatives saw the bureaucracy as a barrier to autocracy that prevented the Czar from obtaining authentic communion with the community of the Orthodox Russian people, or narod. One Russian monarchist politician fantasised about a hypothetical true Czar who "can drive out the worthless official and make the court apply the laws in all their severity". ${ }^{244}$ Lev Tikhomirov, a former revolutionary who came to conservatism with the zeal of a convert, explained the bureaucratic apparatus of the state as forming a barrier between the Czar and the people, subverting the Czar's essential goodwill and preventing

\footnotetext{
244 Loukianov, p765.
} 
abuses being brought to his attention. ${ }^{245}$ This view is echoed by Marxist revolutionaries. Lenin, despite his own legal training and practice, saw bureaucracy as an unmitigated evil despite, or perhaps precisely because, he could not account for the inefficiency of the apparatus of the Russian state through a purely Marxist class analysis. ${ }^{246}$ Those at more moderate points of the political spectrum tended to share this view. This distrust of bureaucracy was not limited to political theorising - Nicolai Gogol's The Overcoat, considered by many to be the foremost Russian novel of the $19^{\text {th }}$ century, is essentially a condemnation of bureaucratic culture.

Unfortunately, given the impossibility of governing a geographically and culturally diverse state such as Russia in even a minimal fashion without a substantial bureaucratic apparatus, it was inevitable that a bureaucracy would exist and form an important part of government. Much conflict over Russian policy-making can be understood as a product of this dichotomy - the need for a bureaucracy and the inability to reconcile public opinion with its existence. But the disdain directed towards Sturmer, and his 'patroness' the Czarina, went above and beyond this generic distaste.

\section{Autocratic Attacks on the Czarina:}

As already discussed, no analysis of governance in Russia can be complete without a review of the meaning of 'autocracy'. It might seem strange that such a discussion should be included in a chapter dedicated to critiques of the Czarina, particularly when a fairly detailed discussion of the 'status quo' role of legality under the Russian monarchy prior to 1917 appeared in chapter one. The reasons for this more detailed examination are twofold. First, although it was not the primary nor the operative (that is, revolutionary) critique of Czarism, the events of 1905 had created a distinct autocratic critique of Czarism-as-it-was, and one with which the person of the Czarina was tightly bound.

\footnotetext{
245 Verner, pp80-4.

${ }^{246}$ Burbank, pp27-8.
} 
The charge levelled by conservative critics of the Czarina was that she was leading her husband to govern in a fashion inconsistent with autocracy. Autocracy occupied the primary position in Uvarov's enduring triad of 'autocracy, orthodoxy, nation', particularly when bearing in mind the ease with which orthodoxy could, at least in a political sense, be collapsed into autocracy. In many ways autocracy in Russia played a parallel role to absolutism in France. To the modern observer, the proud advocates of autocracy might appear to be 'owning up' to tyranny, and it is certainly true that the word 'autocracy' has migrated to the periphery of modern political discourse and now functions essentially as a synonym for non-democratic government, rather like absolutism. This parallel extends to their respective contemporary contexts. Both autocracy and absolutism were conservative philosophies designed to provide a positive, intellectually coherent defense of a system whose practical approach to matters of representation and rights was viewed by many as ipso facto indefensible.

Autocratic thinkers clearly disliked having to provide an explanation of autocracy from first principles. All such explanations carried with them a not always subtle implication that explanations were unecessary as autocracy was natural and organic, and that the very act of questioning it was illegitimate. This constant desire to retreat into mystery and allude to the unknowable is, as Verner notes, characteristic of conservative thought as a whole and allows us to locate autocratic theory in the context of Burkean conservatism. ${ }^{247}$ It is questionable whether theorists of autocracy such as Pobedonostsev, Tikhomirov or even Uvarov were simply codifying an ancient system that had deep roots in Muscovite tradition. Their critics might have charged that they were actually creating a system just as deliberately as their liberal and Bolshevik opponents and using appeals to the unknowable to hide its normative flaws. Ultimately the question of whether autocracy expressed a primal Russia, let alone whether this primal Russia actually existed, is of secondary importance. What is important to note is that claims were repeatedly made in its

\footnotetext{
247 Verner, p72.
} 
name, and that, despite the aversion of many of the most fervent conservative thinkers to nationalism, it bears a strong resemblance to the national ideal of Russia. In other words, Russian autocracy was both more conservative, at least in the Burkean sense, and more national than French absolutism.

The comparison between autocracy in Russia and absolutism in France is closest when their role in the political discourse that shaped the eventual breakdown of both systems is considered. When the two ideologies are compared, there are significant differences. Firstly, while absolutists were establishing a system that they felt could productively be applied universally, or at least to the whole of Christian Europe, autocratists made no claims outside of the borders of Russia and repeatedly stressed that autocracy was a system generated by and suitable only for the narod. ${ }^{248}$ In other words, autocracy was a nationalist concept. Secondly, while absolutist theory emphasised the monarch as standing above the people, communing with them only via narrow, ritualised channels, the autocrat was portrayed as enjoying a profound, ongoing communion with the narod which informed both his benevolence and their obedience. The exact nature of this communion was something that most theorists of autocracy glossed over, seemingly feeling that it was incapable of being described, but it was clear that it was not in any way similar to parliamentary representation. It might be tempting to dismiss this ill-defined communion as simple marketing but it appears to have been taken extremely seriously by autocratists, not least by the autocrat himself. Finally, and least profoundly, autocracy had a more intimate relationship with the established church than its absolutist parallel. The participation and direction of the autocrat in purely religious activities such as the canonisation of saints was seen as a crucial part of the autocratic model in a way that was not true of absolutist monarchs.

\footnotetext{
248 The only exception to this concept was the utter lack of hesitancy autocratist theorists employed when considering the jurisdiction of the autocrat over non-Russian or non-Orthodox subjects. This seems to have implied that, whatever their rhetoric concerning the Russian narod, it was really the Russian Imperial State that autocracy was suited for.
} 
These differences were certainly felt strongly by autocrats. Louis XIV's defenders saw little need to compare him to his then-contemporaries in Russia. But there were many defenders of autocracy who took the time to lay out their own thoughts about the contrast between Russian autocracy and French absolutism. Unsurprisingly, in the eyes of autocracy's defenders, autocracy was superior. Many went so far as to say that absolutism, as manifested in Russia by the Europhile reforms of Peter the Great, was the main thing standing in the path of the enjoyment of the benefits of the autocratic system. Absolutism, therefore, played the same role for Russian autocratists in 1917 that tyranny did for French absolutists in 1789 - an alternative, inferior non-representative form of government that could form one pole of an ideological spectrum, with representation on the other, and the favoured system representing the desired, moderate mid-point. Lev Tikhomirov made the comparison explicit, explaining autocracy as identical to absolute monarchism (a system he saw as existing in Russia since the era of Peter the Great) but invested with an ethical component that he felt European absolutism lacked. ${ }^{249}$ This comparison to absolutism served as the basis for most conservative criticism of government policy, whether it was in the form of friendly criticism aimed at assisting the Czar in reaching the correct judgement or more explicit criticism of a Czarism that was seen as deviating from the correct, authentic and autocratic path. In other words, even those who were derided as proponents of tyranny themselves resorted to narratives of tyranny when engaging in debates within their community of "tyranny"-supporters.

Although we now have a good picture of the theoretical model of autocracy viwed by committed autocracy-supporters ${ }^{250}$ such as as Tikhomirov, Pobedonostsev, Goryemkin and of course the Czar himself, the conservative critique of Czarism was fairly disengaged from this theoretical model. Autocracy-supporters spent much more time dealing with the actual facts on the ground - with finetuning the application of a theoretical model of autocracy that they obviously felt was robust. This

\footnotetext{
249 Verner, p81.

250 This unwieldy term is used advisedly. A supporter of autocracy cannot be termed an autocrat in the same way a supporter of democracy is a democrat, since within autocratic theory the 'autocrat' is the Czar. In these circumstances, brevity must yield to precision.
} 
fine-tuning, particularly after 1905 but generally throughout Nicholas' reign, was not minor. Before the 1905 revolution a combination of basic satisfaction with the status quo and the anti-populist nature of their philosophy meant that autocracy-supporters had been quiescent and tended to avoid public articulation of their views. ${ }^{251}$ After the reforms conservatives continued to insist that nothing had changed, and that the monarch remained the locus of all political power and legitimacy. But while defenders of autocracy chiefly aimed their activism either at their political rivals among the liberal or Bolshevik groups or, less understandably, at ethnic minorities such as Jews and Ukrainians, they were not above criticising the Czar. Their eloquent praises of autocracy as a philosophy and the monarch as a component of governance were directed purely at the idea or the institution of the monarchy; the actual person within it they held no particular brief for, and criticisms of the Czar for inconstancy and weakness eventually became common. ${ }^{252}$

Initially this criticism of the Czar tended to spare the Czarina. Although this chapter will chiefly focus on her actions during the War, it is interesting to note that in the early years of Nicholas' reign the Czarina was generally seen as an ally of court conservatives. In 1905, when hearing a proposal from soon-to-be-Premier Sergei Witte regarding the granting of a constitution, Nicholas twice insisted that the Czarina be present, presumably as a representative of anti-constitutional views. ${ }^{253}$ It is not necessarily clear that conservatives viewed the Czarina as one of their own. After 1905 she had become connected with the concept of 'dynastic decay'. ${ }^{254}$ By the time of the war, conservatives had bought into the narrative that Rasputin and the Czarina had effectively displaced

\footnotetext{
251 Of course the fact that articulation would have been actually illegal prior to 1905 was presumably even more of an issue for autocracy-supporters than their liberal or socialist ideological enemies. Lowe identifies a 1902 demonstration celebrating the anniversary of the end of serfdom as basically a conservative one, due to its patronage by a Grand Duke and a Bishop and the presence of the official anthem and military marches. It appears to have been the exception to the rule, however, and there was considerable trepidation among conservatives who preferred volunteering to organise official public ceremonies than generating their own, even after they became legal. Lowe, Heinz-Deitrich, 'Political Symbols and Rituals of the Russian Right, 1900-1914' in The Slavonic and Eastern European Review, Vol 76, No 3, July 1998, p445.

252 Loukhianov, p766-7.

253 Verner, pp228, 231.

254 Loukhianov, pp767-8.
} 
the Czar, a notion deeply offensive to the autocratic theory outlined above. ${ }^{255}$ The idea that autocratic power could be subverted by personal relationships was deeply troubling to autocracy supporters, who saw the relationship of governance to an actual human being - that is, the Czar - a source of moral strength. To see it instead become a weakness essentially undid the central basis of the autocratic thesis. This may be the reason that there were no Pobedonostsevs or Tikhomirovs in the war era; they viewed autocracy as having been unravelled, and the Czarina, through Rasputin, as responsible.

Part of autocratic frustration at the Czarina and Rasputin may have come from the fact that they potentially represented a potent force for an autocratic revival but refused to affect this role. Rasputin never had any political constituency, despite the original hope that he would represent peasant ambitions. He appears to have had no political goals beyond networking for its own sake Figes mentions that he appears to have actively spurned any attempt to marshal his resources for a purpose, instead being content to see them as evidence of favour. ${ }^{256}$ As such it is not surprising that those groups that did have a particular vision of the way they wanted the Russian state to be ordered - even the conservatives could find no place for Rasputin in it and saw him as an obstacle, potentially the obstacle, to its attainment. And if Rasputin was the obstacle, then the Czarina, who was responsible for his continued presence in such a position of privilege, was also an obstacle.

\section{Corruption and Tyranny:}

The idea of tyranny was not limited to systematic or goal-oriented repression; it was not necessary to claim that the accused tyrant's actions to suppress their subjects would increase the power or personal satisfaction of the tyrant, let alone sustain the system of tyranny. Frequently those who

\footnotetext{
255 Figes and Kolonitskii, pp15-16.

256 Figes, p31.
} 
saw it as their duty to identify such behaviour among tyrants would bring to light cruel deeds without feeling any apparent corresponding need to explain why the tyrant acted in this fashion presumably reasons of personal sadism or power lust were seen as sufficient. Ironically, even defenders of autocracy accepted this possibility by stressing the personal conscience of the autocrat as a contributing factor to autocracy's suitability as a system of government. By making the autocrat's indisposal to perform acts of personal cruelty the main thrust of their reaction to critiques of the autocracy they were elevating the threat of an immoral autocrat, at least in the eyes of those receptive to their narrative, as primary. The 'good character' of the monarch was absolutely crucial, to the extent that when it was necessary for purely practical reasons for the autocrat to delegate authority (a necessity even the most staunch autocrat could not ignore in a state as physically huge, diverse and lacking in infrastructure as Russia) the main concern was to ensure that this good character was replicated in these subordinates. In a society as deeply religious as Russia, this moral quality could only be publicly understood through the lens of religion. Any attempts to depict the Czar, the Czarina or Rasputin as immoral that aspired to have currency outside the narrow spectrum of the elite would necessarily depend on religious ideas of what morality was.

Popular opinion among Russian peasants can be difficult to discern, but in religious matters there were many opportunities for public expression of strong views even among illiterate and otherwise marginalised members of the narod. To some extent their political views can also be extrapolated this way. This attempt to extrapolate the political from the religious is not quite as strained as it might seem, although difficulties do need to be acknowledged. It needs to be emphasised that the divide between the religious world and the political world, particularly as pertains to the correct role of the royal family, was not something that most Russian peasants accepted. Through the office of the Holy Synod the Russian government was firmly in institutional control of the Orthodox Church. For most Russians the Czar was first and foremost their 'little father', a combination of patriarch of 
some vague extended family and exemplar of Christian values far more than he was their head of state, or even the dynast of the realm they owed fealty to.

A religious concept that peasants placed an extremely high premium on was that of netlenie, a term best translated as 'absence of corruption'. In its most narrow use netlenie is a religious term, one that is used to describe the remains of a saint who, through thaumaturgy, has been able to evade physical decay. So concerned were peasants with netlenie, despite the fact that it was not officially a requirement for canonisation in Orthodox doctrine, that substantial moves were often made to conceal the decay of Saints' bodies and the discovery of degradation was often greeted with horror, as in Dostoevsky's Brothers Karazamov, or widespread apathy towards the actual holiness of the purported but corrupted saint. ${ }^{257}$ The Soviets understood this popular concern and were not above manipulating it, either in the negative, such as during their campaign to open the tombs of Orthodox saints, or in the positive, the most obvious example of which being the preservation of the corpse of Lenin (and briefly Stalin) in Red Square in a conscious replication of Orthodox tradition, right down to the red velvet lined coffin.

The idea of purity of the corpse translates relatively easily to that of purity of the living body and the personal morals, something that is best illustrated by the appropriation of the English term 'corruption', originally meaning something very similar to netlenie, to refer to illegitimate practices in the public sphere. Czarist government was often characterised as corrupt in this sense, but due in part to an importation of the Orthodox popular obsession with incorruption and in part to the moralistic foundations of autocratic rhetoric in personal virtue, these charges were particularly damaging. This moral imperative was acknowledged by the Czar's advisors, who undertook an attempt to reconnect the Czar's public image with the popular piousness of Russian Christians -

257 Freeze, 'Religion and the Political Crisis', pp316, 320-1. 
what Freeze has termed a 'resacralisation' of the Romanov monarchy. ${ }^{258}$ This resacralisation was an attempt not only to assert the morality of the Czar and, by association, his servants but to elevate them at least partly to a realm above morality through persistent association with the symbols of divinity, namely historical saints. It was first and foremost an acknowledgement of the moral dimension of the tyrannical critique and the primacy of religion in any moral narrative. In many cases, particularly that of Saint Germogen, there was a nationalist dimension to this resacralisation, but it can chiefly be understood as an attempt to counter a moral critique.

This popular religious component of morality would seem to lead to a positive view of the Czarina, who conspicuously concerned herself with religious practice and observance. Unfortunately, the Czarina's personal devotion chiefly manifested itself through her association with Rasputin. Rasputin did not satisfy the prevailing Orthodox equation of morality with non-corruption, both in the personal and public spheres. His revelling in personal degradation through drinking and promiscuity was equalled only by his open exploitation of a system of bribery and personal favours. Once again, as with her urging of the Czar to go to Mogilev, a tendency that might have been initiated specifically to end perceptions of tyranny had the effect of encouraging them.

For those in Russian society who did not subscribe to the religious view of moralism, an alternative was available. Outside peasant society, the hard sciences enjoyed a high level of prestige in Russian society and the logic of medicine and biology was often applied to social problems. ${ }^{259}$ This prestige may well have been due to elite shame at the perception of Russia as backward and undeveloped, particularly in contrast to the common western European referent societies of France, Germany and the United Kingdom, which led to a desire to close the gap by closely following and hoping to emulate (and eventually recreate) the scientific advances that arose in these countries. ${ }^{260}$ In practice

\footnotetext{
258 Freeze, 'Religion and the Political Crisis', p310.

259 Beer, Daniel, 'Microbes of the Mind: Moral Contagion in Late Imperial Russia' in The Journal of Modern History, Vol 79, September 2007, University of Chicago Press, pp533-5.

260 While Russia during the pre-revolutionary years of the twentieth century was able to compete with Western Europe
} 
this 'biologisation of the social' led to a privileging of the rational over the emotional, which further translated into a disdain for the activities of crowds and the rational capacities of crowd members in a political sense, demonstrators - and the legitimisation of moral outrage through medical language. This biologisation, which tended to be allied to relatively conservative critiques surrounding sexual morality and personal indulgence, offered those who disdained religion as a guide to the universe grounds to make parallel criticisms of the Czarina and her entourage on grounds of promiscuity and immorality.

\section{Non-Democracy:}

The term 'democracy' had an extremely potent political currency in Russia during the period of the Czar's deposition, among groups as diverse as the supporters of General Kornilov and Lenin. ${ }^{261}$ It is possible to speculate that this 'democracy' did not involve a commitment to anything substantially resembling Western democracy, and it is certainly defensible to assume that in a state as vast and fractious as Russia, and one enduring a very rapid political education, no single definition of what democracy involved could be agreed upon. It might be assumed that, at a minimum, democracy involved a commitment to opposition to Czarism, but the oft-quoted statement by a Russian soldier that Russia needed to 'elect a Czar' seems to throw even this into doubt. It would certainly be wrong to underestimate the personal attachment of many Russian peasants to the Czar, and it would be remiss not to acknowledge that prior to the events of 1917 even the most radical Duma politicians saw a role for the Czar in the system they wanted to establish - in one memorable meeting between liberals and conservatives, future Foreign Minister Pavel Miliukov insisted that 'we are all monarchists'. Despite this, the continuing hope of peasants for a 'good Czar' is more likely to be a matter of language than political theory. We should view the peasant who speaks of a

in terms of arts and literature - figures such as Tolstoi and Stravinsky commanded attention and respect throughout the world - the flow of scientific innovation was strictly one way.

${ }^{261}$ Kolonitskii, Boris, '’Democracy" in the Russian Political Consciousness of the February Revolution', in Slavic Review, Vol 57, No 1, Spring 1998, pp96-7. 
republic headed by an elected Czar as somebody who is struggling to use inadequate language to express clear views, and be more impressed by the fact that the peasant is able to clearly express the meaning of the term 'republic' than his apparent unfamiliarity with the term 'president'. And while some theoretical reconciliation of the institution of Czardom might have been compatible with the democracy that the Duma liberals sought, it was impossible for that Czardom to incorporate the system of personal autocracy promoted by Nicholas, let alone Nicholas himself. The very same Miliukov who proclaimed monarchism as a universal value had no compunctions about describing Nicholas as a despot. ${ }^{262}$

These non-democratic practices on the part of the Czarina went beyond abstract disregard for democracy. The idea that a tyrant causes his people to suffer is crucial to the concept of tyranny. Although it would be wrong to neglect the suffering on every level - emotional as well as physical - that afflicted the life of Russian peasants long before the assassination of Franz Ferdinand, to speak of suffering in the context of Alexandra Fedorovna's 'reign' is to focus almost exclusively on the conduct of the Great War. Although the Eastern Front was spared some of the more characteristic features of warfare in France and Belgium, notably trenches and tanks, the casualties suffered by the Russian army were comparable to those inflicted on their French and British allies. Stories about Alexandra's influence on the conduct of the Eastern Front have already been analysed as part of the previous discussion of nationalism, but while the prosecution of war is obviously important to ideas of nationalism, it is also relevant to tyranny. No discussion of the criticisms levelled at the Czarina for her indifference towards the well-being of her subjects would be complete without reference to the Great War.

Most of those who criticised the Czar as a tyrant were in favour of continuing the war. This did not mean that they did not view the Czar as causing suffering to his subjects, but they placed the blame

\footnotetext{
262 Stockdale, p246.
} 
for the pain and dislocation that the war caused, not on the decision to enter and remain in the war, but on the manner in which the war was prosecuted. The fact of war was the fault, presumably, of the Kaiser, but the practice of the war was the fault of the Czar - and increasingly, as the Czar came to be seen as a nullity, of the Czarina. But even those who saw the war as an unworthy enterprise often found further fault in the manner in which it was prosecuted. Pavel Miliukov summed up this dichotomy in his 1916 Duma speech, in which he listed a series of the government's perceived failures and asked the question - 'stupidity or treason'?263. Even to those who, like Miliukov, rejected the charge of treason, the charge of stupidity remained formidable, because the advent of warfare elevated government incompetence to a matter of routine life and death. This charge of the Czarina as causing the suffering of her husband's subjects was particularly stringent when Rasputin entered the picture. Prince Yusupov, in his justificatory memoir, mourned that if he did not kill Rasputin 'all the blood poured out by Russians would be spilt in vain' and that defeat would be 'the tragic end of the nation's enthusiasm' ${ }^{264}$ Leaving aside the fact that only the most optimistic commentator could describe Russian in 1916 as being in a state of 'enthusiasm' this narrative is one that, if one is prepared to interpret the word 'nation' as simply referring to the polity rather than the narod, is one oriented towards a desire to prevent suffering and sustain popular participation in government - in other words, to mitigate tyranny with good governance.

Throughout the early years of war two major narratives developed among the educated classes who, perhaps unknowingly, were future revolutionaries. The first, which has already partly been discussed in the chapter on nationalism, was the 'spy mania' identified by Fuller. Spy mania had implications beyond the very significant effects on Russian self-identity that have already been identified. It is worth noting that although popular suspicions focused heavily on Germans and Jews, the two individuals mostly prominently identified as subversives of the Russian war effort,

\footnotetext{
263 Stockdale, pp234-6.

264 Yousoupoff, p72
} 
Sergei Miesadov and Vladimir Sukhomlinov, were both ethnic Russians. ${ }^{265}$ For the first time in Russian history discussions of the mechanics of espionage - of secret meetings, coded documents, concealed radio transmitters and false fronts of loyalty - entered the public discourse at a prominent level, and essentially never left them, even when the direct threat of wartime espionage departed. The Miesadov Affair, as it became known, energised and captured public opinion in a way similar to that of a pulp spy novel, not least because its content bore no small resemblance to one.

This popular belief in conspiracy allied itself with the second narrative, which was the belief that the conspicuous failure of Russia to successfully prosecute the war against the Central Powers was due to the state's failure to harness Russian society in the cause of supporting the army. ${ }^{266}$ This belief, that there were tremendous energies replete among the Russian populace and represented by the Duma and the local government structures which the Czarist government was refusing to permit to come to the rescue of the military, was phrased essentially as a Czarist fear of the authentic popular Russia and to a lesser extent the institutions which incarnated it. In other words, the authentic, deep Russia was offering collaboration with the shallow, surface, political Russia, a collaboration which was rejected for selfish reasons. Although this narrative was probably not originally intended to be a delegitimisation of the Czar's government, it became increasingly difficult to explain why the government would reject such collaboration if the price of doing so was defeat. Harking back to Miliukov's dichotomy of stupidity against treason, the charge of stupidity became increasingly difficult to sustain, since a government that was unable to understand the best way to defend itself against foreign attack could not credibly be able to make similar calculations in repelling an internal foe. If the Czar and his ministers really were stupid, they were selectively stupid in a way that was not credible. Blindness and oafishness towards the military situation but cold-hearted rationalism towards the internal situation, particularly when the latter implied making

\footnotetext{
265 Admittedly, Miesadov had had close dealings with Germans and Jews throughout his lifetime, but this did not feature prominently in the rumours that surrounded him - he was simply 'the traitor Miesadov'.

266 Fuller, pp196-201.
} 
significant sacrifices, could not really be construted as an alternative to treason, since it effectively was treason, albeit treason of a rather characteristic type.

Most historians tend to agree that the real cause of the Russian army's defeat was not the personal inefficiency or treachery of individual Russian officers, nor the government's failure to harness the resources of Russian civil society, but rather the deficiency of the Russian army in several key areas, most notably armaments. ${ }^{267}$ The idea that the army was a faulty instrument for national policy had little currency at the time - it seems that wartime propaganda aimed at depicting the army as an authentic representation of the Russian people, rather than the coercive engine of last resort of the autocratic state, was successful. This is illustrated both in the personal popularity of Grand Duke Nicolai and the fact that several senior officers, notably Brusilov, Kornilov and Alexeev were enthusiastic supporters of the provisional government. This position meant that the army's objective failures could only be explained by subversion. 'Bad apples' might have credibly, if only barely, explained the failure of certain operations such as the defeat at Tannenburg. But, systematic operational failures, such as the continual failure to supply adequate artillery or the inability to manage the railways sufficiently competently to ensure simultaneous supply of food to both the armed forces and the cities could only be explained by equally systemic treachery treachery too systemic to be addressed by counter-intelligence, treachery whose solution could not be confined to military procedures but must be addressed at the level of the state.

\section{Czarina as a tyrant:}

The overall trend of this chapter has been one of disparity. This is because the narrative that depicted Alexandra Fedorovna as a tyrant was not a neat one. Of course very few things that

\footnotetext{
267 Russian troops were famously deployed to the battlefield without rifles and told to scavenge them from captured enemies or fallen friends. Possibly even more damningly, given the critical nature of artillery during the Great War, Russian forces were often crucially short of heavy field guns and ammunition for them.
} 
encapsulate diverse societies over long periods of time can be considered 'neat' in the meaningful sense but even given this consideration the Czarina's image is fractured. This should not be taken as de-emphasising the degree to which she was seen as creating tyranny. If anything the fact that groups as disparate as traditionalist autocrats and revolutionary socialists could unite around her tyrannical image shows just how powerful was the belief in the existence of tyranny, and the Czarina's place at its centre. 


\section{CHAPTER EIGHT:}

\section{CONCLUSIONS}

We have seen over previous chapters the broad shape of the political lives of Marie Antoinette and Alexandra Fedorovna. The purpose of this thesis was not simply to provide a chronology of events or a presentation of anecdotes, both of which have been done more comprehensively and effectively than this piece can aspire to. Instead, the aim of has been to reach a position where we are able to claim an understanding of the underlying narratives dictating the commonalities and discrepancies between the manners in which tyranny, nation and gender were treated by the participants of the French and Russian revolutions. The two women whose lives we have followed form narrower personal case studies within the broader state-level case studies. But if this was the limit of the author's aspirations, this work would have little purpose. Each of these concepts has been reviewed in the writings of the many authors whose works have been used as references for the work up until this point. It is not that there is nothing further to be written concerning, say, gender roles up to and during the French revolution, it is simply that to be able to make confident statements advancing the field in this area would require a breadth and depth of research to which the author cannot currently aspire.

Where the author does feel able to make a contribution is in the more limited, but potentially just as revealing, area where these three points of criticism 'converge'. Convergence is a term used advisedly for it implies that the meeting of ideas about women, foreigners and tyrants in a single arena - which could be as small as the mind of a single person or as large as a national policy debate - mingle, merge and form a conglomerate concept. This is not the process that is envisaged as taking place. Instead, almost the opposite chain of events is postulated - that a pre-existing and not necessarily very articulate idea about how policy should be formed found expression through 
relatively narrow concerns regarding the appropriateness of people of a certain gender, a certain national origin or a certain disposition towards political office-holding achieving positions of power within the state. Those who experienced this sentiment did not take the time to explain it but there is no reason analysts need follow their example. Even if we do not view the decades which have passed since the times under analysis as granting us any licence to regard ourselves as more insightful than the actors in question, we are not burdened by the need to sacrifice self-analysis and explanatory sophistication in order to achieve the emotive and brief expression necessary for oppositional agitation. It is this necessity which means we have had to take this three-pronged, diffuse approach to understanding of the real subject matter of this work, which if approached directly, would be either absent or formless.

The hypothesis of this work is that when actors spoke about gender, or tyranny, or nation, in their minds and in the minds of their listeners, they often meant essentially the same thing, and either knowingly, unknowingly or even semi-knowingly simply fitted the facts of their communication to whatever was most contextually appropriate. The question that cannot be avoided then becomes what was it they actually would have spoken of, if the practical demands of building a revolution had been lifted from them and their introspection had been given free reign? What was the concept that found expression through the filters of gender, nation and tyranny?

\section{Influence:}

Readers are unlikely to expect an answer to this question in one word, not least because it has taken seven chapters to be in a position to be able to effectively answer it, but if a one word answer was necessary it would be 'influence'. This answer, unsurprisingly, is not a revelatory one - the word 'influence' is by its very nature both a word that describes ambiguous conditions and has a high 
degree of ambiguity in and of itself. To successfully describe the reality of the ideas that led to the Franco-Russian revolutions, it is necessary to problematise the word 'influence' and arrive at a more nuanced definition.

The term 'influence', as has already been noted, has an existing pedigree in the literature, and its use here is intended more narrowly than it might be if encountered elsewhere. Probably the most comprehensive definition of the term is that offered by Ruth Zimmerling, in which she identifies influence as 'the ability to affect other's beliefs, that is their knowledge or opinions of... what is (empirically) true or false or what is (normatively) right or wrong'. ${ }^{268}$ This contrasts with power, which is defined as 'making others do what one wants'. ${ }^{269}$ Zimmerling's explanation for influence treats it as a quality that a relationship between two actors, individual or group, might have, but this thesis will propose a definition of influence which, while not entirely separate from Zimmerling's, is less a description of a quality relationships can have and more of a characteristic of a framing system within which relationships take place. Certainly when the revolutionaries criticised Marie Antoinette or the Czarina they rarely limited their criticisms to any particular relationship between the monarchs and any other group or person, let alone any interaction - such a criticism would be an inappropriate tocsin for an overthrow of government.

But it is not sufficient to describe a situation of influence as one where influence as described by Zimmerling is the norm or the preferred method of achieving goals. Ultimately Zimmerling's definitions are less useful for describing two distinct methods of achieving policy goals than they are for describing two ways of looking at coercion. Whether the imposition of a certain policy is described as a result of influence or power is largely a matter of perspective and tends to depend on exactly how one defines voluntary action. Almost no action, particularly that with political

\footnotetext{
268 Zimmerling, Ruth, Influence and Power: Variations on a Messy Theme, Springer Netherlands, 2005, p141.

269 Ibid, p141.
} 
significance, is ever undertaken entirely voluntarily or entirely due to some outside imposition. When the Czar decided that there would be a ban on alcohol sales for the duration of the Great War, he was not able to directly force every storekeeper or salesperson to dispose of their stocks and refrain from future sales. Nonetheless the ban was complied with. Some of the alcohol vendors may have genuinely felt that the sale of alcohol at a time when ordinary Russians were being called on to sacrifice themselves was wrong, and that the Czar's proclamation either made it so or drew their attention to something they should have realised themselves, making the formal proclamation simply a guide for action - a clear case of influence. Others may have been less convinced that there was anything morally wrong with their business but felt that they had a moral duty to obey the Czar even when his commands made no sense to them. Even those who feared prosecution were not having a decision imposed on them so much as they were responding to a changed set of incentives not all of which may have been related to a fear of imprisonment. If the passage of a formal law requiring discrete and unambiguous action can be described as a product of influence, is there any room for power? Conversely, the fact that the law was widely subverted and treated by many, even those who had no particular financial or recreational interest in the sale of alcohol, as an annoyance that they were justified in working around if they were able to, seems to imply that it was powerless without formal correctional instruments of punishment and compulsion. Almost any other concrete policy example can be viewed as a product of influence rather than power if one chooses to emphasise the non-coercive, persuasive elements of its implementation.

Both 'power' and 'influence' as explained by Zimmerling are relatively neutral concepts. In some situations, according to Zimmerman's conception, it may be better to use power, in others influence may be superior. Without meaning to dispute or condemn her refusal to place a qualitative moral signifier on either, it is possible to conceive of a viewpoint where influence, as determined by her definition, is an unambiguously negative phenomenon - one so negative, in fact, that its cessation 
and prevention can become the overriding goal behind the overthrow of an entire political system.

\section{The Problem of Influence:}

It is difficult to underestimate the importance of the enlightenment in setting the intellectual and conceptual landscape of the French and Russian revolutions; both revolutions can readily be understood as attempts to act out the modernist philosophical project on the political stage. What English speakers call the 'enlightenment' was known in the francophone world as the Illumine, a word whose meaning is closer to 'casting of light' than 'enlightenment', and has more implications of making visible what was previously hidden and clarifying what was previously muddled or obscure. Both the French and Russian revolutions were initially energised and legitimised by the language of the enlightenment and its attendant quest to understand and achieve modernity. Influence stands in opposition to this illumination - influence is played out behind closed doors, outside of formal offices and in the legal grey areas left by imprecise or overly general laws and provisions. Just as the light of the Illumine, when applied to the physical structures of the natural world, expelled faith and mysticism in favour of science and rationalism, the same light, when shone on the legal and social structures of the political world, expelled influence in favour of power.

A meta-theme running through this concept of influence is one of opposition to what is natural, easy and even everyday. To be foreign, to be female in anything other than the accepted manner and to be tyrannical are all ways to be outside of the organic community which, in the enlightenment paradigm, provides legitimacy. It is seen as the product of artifice - and not artifice obtained from the natural wellspring of human ingenuity or exercise of god-given qualities and preponderances, but rather artifice designed to subvert, suppress and exploit these qualities. If a governmental system organised around the authentic wishes of humans will give rise to a Republic in the sense 
that Plato defined it and Rousseau attempted to realise it, a governmental system desired to subvert and elide these authentic desires will result in a tyranny which, as we have seen, is defined as not even being in the tyrant's interest. Similarly, the political role of women becomes controversial only when they evade the authentic sphere of their ambitions and seek to masculinise or de-feminise themselves. And of course, perhaps least requiring of explanation but most revelatory, there is the dichotomy of the national against the foreign; while the former is relevant to the deep traditions which form the basis of the nationalist idea, the latter is, at least within context, foreign to the very environment they operate in. One of the overriding themes is inauthenticity, of strenuous effort opposing innate dynamics, of artifice that cannot be sustained and whose inevitable collapse only drives its practitioners to more devious ends.

One of the main reasons rule by influence is easily portrayed as unsuitable is that it is of itself unsustainable. The idea that governance is an ongoing, never ending process of attempting to reconcile diverse interests and meet common ground that does not necessarily form a direct reflection of anybody's foremost wishes or genuine preferences and needs was not one that was amenable to the revolutionaries of France and Russia. The revolutionaries aspired to a political system that would reflect a single, universal understanding of the ordering of public life that was reflected by the manifestation of values that they saw as similarly universal to their rightful political prominence. In other words, they sought a scenario where the right thing to do would always be obvious, where there would be no need to consult diverse interest groups or abandon one's desire for the perfect expression of one's political ideals, merely to attend to the expressed wish of the people which would of necessity be clear, uncontradictory and unanimous. Susan Dunn describes the political state that the Jacobins wished to achieve as one of 'sanctity'. ${ }^{270}$ The word may seem at first inappropriate but it is worth noting that the Christian notion of sanctity is as much one of repose as it is anything else. Sanctity does not need to be constantly negotiated and transacted. For

270 Dunn, p20. 
a political system to reflect the state of supernatural grace that was the goal of the preenlightenment European, it could not be reflective of this hustling, boisterous energy, which alienated those who sought comfort and legitimacy in images of predestination and the leisurely pursuit of a pre-ordained plan. Just as enlightenment impulses away from biological determinism, parochialism and moralism found their expression by playing on unease about gender roles, foreigners and immoral rulers, enlightenment deism and agnosticism received a significant boost from a suspicion of government by influence based largely on political ideas derived from the teachings of the church.

\section{Gender, Nation, Tyranny and Influence:}

The overall narratives of criticism that have built up around Marie Antoinette and Alexandra Fedorovna are excellent examples of the phenomenon of the concept of influence being deployed to channel and energise people to act on their alienation.

As already mentioned it is easier to speak of views of Marie Antoinette as a 'bad woman' than as a woman. In setting out an ideal image of a woman and then placing Marie Antoinette's behaviour in opposition to this, the revolutionaries were able to portray her as somehow unnatural and even alien to the everyday life of her subjects. This concept of unsuitable femaleness is combined into a single narrative during discussions of the Diamond Necklace Affair and later the flight to Varennes. In both cases all three critiques of Marie Antoinette combine into one virtually seamless narrative where ideas of nationalism, gender and tyranny become intermixed until they are impossible to extricate, and the only retrievable concept is that of a fear of influence. 
In attempting to remove themselves from Paris the royal family were both attempting to distance themselves, physically and politically, from the locus of popular power and its incarnations in the commune government and the National Assembly, and from the political and physical heart of the nation. Similarly their projected protector, the Emperor in Vienna, was an unacceptable figure to associate themselves with both due to his status as a despot ignorant of the needs of his people and due to the fact that he and his subjects were not French. The outrage that this event provoked also had a gendered element, as it was not only seen as a sexual collusion between Marie Antoinette and her lover, Count Fersen, it also hinted at an improper prioritisation of relations with her family, the Hapsburgs, over her husband's family, the Bourbons, something that flew in the face of the traditional French idea of marriage as it existed at the time.

The flight to Varennes was not, however, a unique incident. During the Diamond Necklace Affair, the Queen's spendthrift nature and penchant for secrecy were emphasised as a way to play on her gender - but the same concerns could easily be interpreted as evoking the hostility owed to tyrants. There was even a nationalist angle to the issue, which, although peripheral, is revealing - the inclusion of Count Cagliostro, a foreign exotic popular at the Parisian courts but also generally connected with an air of exotic scandal, served to give the affair a nationalist flavour it would otherwise have been lacking. It is certainly worth noting that, although the affair itself does not appear to be an issue of concern to nationalists, the parlements who used it as a welcome medium through which to attack the King had previously cut their teeth in disputes with the King on purely nationalist grounds, eg the dispute over the rights of Jansenists in the face of Papal censure.

Unsurprisingly there are similar examples of these three narratives uniting in the Russian case study. The person of Rasputin, or more accurately the massively unpopular public persona of Rasputin, offers ample evidence of the conflation of the three points. The Czarina's relationship 
with Rasputin was seen as evidence of her disdain for the genuine representatives of the Russian people in favour of corrupt court camarillas. Nationalists, particularly during the Great War, focused on Rasputin's purported undermining of Russia's military effectiveness. And the persistent rumours that the Czarina had allowed the starets sexual access to her children depicted her as inadequate as a woman. Often these narratives fed into her - for instance, her perceived excessive devotion to her son, a very feminine characteristic, was seen as giving Rasputin power over her through his supposed ability to put the child's haemophilia into remission temporarily.

A similar juxtaposition of the three themes came with the Czar's assumption of the role of commander-in-chief of the armed forces. We have already seen the manner in which Alexandra Fedorovna's role in the appointment was brought to centre stage by her critics. In doing so they not only saw Alexandra as promoting her own, illegitimate and undemocratic role in government by usurping the rightful functions of the head of state, the frequent rumours that the Czar's physical removal would facilitate her sexual relations with Rasputin allied this critique to one that emphasised the Czarina's status as a woman, while the urgency of maintaining military efficiency and security during wartime added the necessary nationalist emphasis to the event.

These are not the only moments where gender, nation and tyranny converge. We have also seen multiple moments when two of these concepts came together in the absence of the third. For instance, French Austrophobia was based on a nationalism which saw Austria not only as a foreign nation but as an oppressor of the very idea of nations, but also on a perception of Austria as a 'bad international citizen' in its habitual refusal to abide by agreements or respect the rights of other states - in other words, to practice a tyranny within the community of nations. A similar conflation occurred in Russia where the appointment of Boris Sturmer to the Premiership raised fears both of excessive influence of courtiers in government and of surrender to Russia's wartime enemies. 
The pattern, though, is clear. Although there are points where each woman was critiqued on purely gender, nationalist or tyranny-based grounds, it is impossible to follow each chain of criticism very far without finding it combining with the other two, nor is it possible to systematically review all three without seeing the similarities. And it is around the concept of influence that these similarities and convergences occur.

\section{Other Components of Influence:}

The concept of influence is an extremely wide ranging one and it would be wrong to suggest that the three subsidiary concepts identified here are its sole constituents. It is outside the scope of this piece, once again, to speculate on the degree to which any of these three concepts contributes to the concept in the totality of its existence throughout different times and different locations. While it might be estimated without too much fear of contradiction in later studies that tyranny, for instance, was a relatively frequent feature of the stories told about influence, with gender a less common contributor, these would only be guesses.

What can be stated with confidence even when limiting our ability to make authoritative statements to those case studies covered here is that there are other ways to approach the confluence of influence indirectly through the dialogue than those contained in this thesis. What has been discussed here is definitely sufficient to understand the way ideas about influence flourished amid, energised and legitimised the political landscapes of revolutionary France and Russia but it cannot claim to be a definitive review of every method that those who detected influence and sought to eradicate it from government used to illuminate their concerns. 
But the concept of influence is broad and diffuse enough that one would not expect it to confine itself to manifesting through the prisms of gender, nation and tyranny. If we are to accept its existence we must assume and expect that it will manifest itself more broadly and diffusely. If called on to identify a potential fourth factor in the conception of influence the most obvious avenue that could bear further exploration is that of religion. Of course religious ideas have already been explored in this thesis; we have spoken of the netlenie of Russian orthodox believers concerned with corruption in both the physical and political senses; we have reviewed the propensity of French observers to equate Austrian ultramontane Catholicism with political traditions alien to France, and we have discussed at length the role of Rasputin in subverting the Czarina's sexuality. The fact that religion has frequently cropped up as a lens through which nationalism, gender and tyranny can be understood is revealing. If nationalism, for instance, was not specifically addressed, we would still see its echoes in discussions of gender and tyranny. In the same sense these issues of religion might be seen as echoes of a religious dimension to influence.

It is not hard, without immersing oneself in the extensive literature concerning religious politics in France and Russia, to imagine the shape religious ideas about influence might take. In Russia, where the Orthodox Church had been firmly administratively and legally connected to the state since the reign of Peter the Great and, to the persons of the Czars since the ascension of the Romanov dynasty, there was a perception that Orthodox Christianity was more open and more authentic than the Catholic or Protestant christianities of Western Europe, let alone the Islam or Buddhism of Russia's Asiatic neighbours. Praise for the Orthodox faith by Russian thinkers often took the form of eulogising its simple and unpretentious nature. One might think that the Czarina's conversion from Protestantism to Orthodoxy would have offered grounds for criticism, with suspicion that the conversion was inauthentic or false, but there does not seem to have been any basis for this - while her German background led to her being accused of being unfaithful to the 
Russian state, it did not follow that she was seen as unfaithful to the Russian religion.

If anything, as we have already touched on in our review of the Czarina's relationship with Rasputin, the Czarina was accused of being overly religious, or at least religious in a way that was not simple or unpretentious, that valorised lavish declarations over simple devotion. Her gifts of money to religious charities did little to assuage this criticism - since it was not a model of faith that the public as a whole could follow, not enjoying the lavish financial resources that she did, it was of little value to establishing a claim to faith that was resistant to accusations of influence. When the Czarina began to give her labour as well as her capital to religious causes, most notably volunteering as a nursing sister, she was in part responding to this criticism, although obviously insufficiently to ward off the charge. It is notable that prominent religious figures gave little support to the royal family as the Romanov's reputation declined. Freeze has written of the 'desacralisation' of the monarchy. ${ }^{271}$ 'Sacred' is perhaps not quite the right word to use for the religious status of the monarchy prior to the reign of Nicholas II, because to be sacred is to be above material concerns, while the valourised unpretentious, heartfelt religious practice that was expected of them does not fit entirely with the concept of 'sacred'. But if the opposite of 'sacred' is 'profane', this is definitely a good word to use for the religious image that the monarchs, despite their sporadic and ill-advised attempts to regain their tarnished mantle, eventually acquired.

Of course Russia, like its contemporary Great Power rivals France, Britain, Austria and Germany, was an Empire, and like them it had to sacrifice its homogeneity in order to achieve this Imperial status. ${ }^{272}$ The price tag of this homogeneity mostly came in ethnic terms, with Russians not even constituting a majority in their own Empire, but the Russian Empire also encompassed large groups of people who did not adhere to the Orthodox church. Leaving aside the atheism or illumine deism

\footnotetext{
271 Freeze, p349

272 Miller, Alexei, The Romanov Empire and Nationalism: Essays in the Methodology of Historical Research, Serguei Dobrynin trans, Central European University Press, Budapest, 2008, p32.
} 
of the urban cosmopolitan elites, non-Orthdox Russians ranged from the Lutherans of Finland and the Baltic, to the Catholics and crypto-Catholic Uniates of the Poles and Ukrainians, to the Buddhist Kalmyks and Siberians, and the Muslims of the Caucasus and Central Asia. Russian nationalism was, as has been discussed in chapter five, as much a reaction to this Imperial confessional diversity as it was to anything else. But while the majority of the Czar's subjects were not Orthodox, it was Orthodox Christians who exercised a near total monopoly on the policy-making elite in St Petersburg, to the point that even Baltic Germans, a group actually over-represented among senior bureaucrats and ministers in comparison to Great Russians, often favoured conversion to Orthodoxy in order to make their Imperial service less jarring to the Orthodox orthodoxy. The fact that it was possible to form a public narrative that depended on a confessional status that most of the Empire's subjects did not share is less of a weakness in the conception of influence and more a weakness in the idea of what constituted the Russian state by those who sought to utilise the Czarina's 'influence' to remake that state. Whether it was sheer ignorance or a Kipling-esque belief that, should they construct a suitably appealing citizenship-based Imperial identity the various nonOrthodox, non-Great Russian subjects of the Czars would be irrevocably drawn to it and submerge their particular identities in a rejuvenated Russians state is an interesting question but one only peripherally relevant to the idea we are concerned in this thesis.

In France the picture is less clear, largely because, unlike Russia, France did not have a single religion that commanded the adherence of a majority of its citizens and the vast majority of its elite and was simultaneously near-unique to the state. France was, despite the persistence of communities of protestants and Jews, overwhelmingly Catholic, but it was not even close to unique in this; France was part of (indeed arguably the heart of) the wider community of Catholic Europe. In protestant states, notably England (on which more later), Catholicism is often associated with influence, and the hidebound, obscure and arcane practices of Catholic ritual are an extremely good 
fit for influence narratives. The sanctity of the confession is a religious endorsement of the notion of secrecy. The Catholic refusal to communicate in a language accessible to anybody other than an elite closed by access to privilege (in the form of a classical, Latin education) creates the very picture of a closed policy making community. Catholic sanctification of various esoteric religious rituals offers the general air of the bizarre which can do so much to enhance and vilify the practice of influence. Frequent Catholic pronunciations of the virtues of mysteries only adds to the picture. And while there is nothing in Catholic doctrine or religious practice to specifically encourage the advancement of the personal interests of the Church's magnates, only the most superficial review of the actual practice of Church governance is required to find a cornucopia of anecdotes confirming the image of the greedy cleric, be he a village priest or a cardinal, using his position to advance his interests, even if we limit ourselves to France proper.

The popularity of Jansenism, particularly among the French elites who constituted or supported the parlements during their pre-revolutionary disputes with Louis XVI and his predecessor, speaks in part to this conception of Catholicism as a conspiratorial, unnatural and inauthentic form of government. While the theological basis of Jansenism was, without wishing to go into an analytical cul de sac in which the author is not qualified to give substantive analysis, not sufficiently distinct from counter-Reformation Catholic doctrine to lead to the significant rifts in French political society which were described in chapter six, this asynchronicity between Jansenism's theological dictates and its political consequences proves the point being made within this chapter. Jansenism's popularity in France was less to do with any particular merits or implications of the application of its theological ideas to the political world, still less to do with those ideas taken in isolation; it was, rather, a reaction away from the influence-based conception of Catholic public life that was only constrained within the bounds of Catholic dogma due to a nationalist desire to avoid a by-the-book emulation of Anglo-German Protestantism and thus confess that France was embarking in deference 
on a path blazed in its entirety by perennial defining enemies Angleterre and Allemagne. In a sense, then, the Catholic theologians who charged that Jansenism was simply an ersatz Lutheranism in crypto-Catholic garb were, at least in the political sense, entirely justified, and the theology's lack of success outside of France, where it succeeded in large part due to the patronage of parlementaires and other would-be policy-makers seeking an ideological cloak under which to assail the monarchy is as eloquent an illustration of this point as could be hoped for.

\section{Influence in the World:}

As has already been mentioned the concept of influence and the need to expunge it from public life has a pedigree that extends well beyond revolutionary France and Russia. These two examples seem meaningful but it does not follow that they are the only examples. If a third case study for the role of influence in creating a public narrative demanding revolution were to be proved necessary it is likely that the most attractive example would be England during the period prior to the Civil War.

The parallels between the executions of Czar Nicholas, King Louis XVI and King Charles I, and the political agitation that led up to their executions, scarcely need to have attention drawn to them. In the same manner that Kerensky diligently studied the final days of Louis XVI in the hope of gaining some insight into the situation in Russia, so too did Louis XVI read the biography of his counterpart and ancestor Charles I in the hope of learning something from his mistakes. Although Kerensky and Louis were both crucially bad at discerning the context they were operating in there is much to suggest that in drawing this chain of causation between the events of 1649,1792 and 1917 they were identifying a parallel that, even if it did not assist them in changing their own situations, historians might do well to pursue deeper. 
Generally the term 'revolution' is not attached to the events that led to the English Civil War, although it is, confusingly, used for 1688's 'Glorious Revolution', an event which has more of the character of a consolidation than an overthrow of the existing social order. Nonetheless there is much to support the idea that what occurred in England prior to the King's death had the character of a genuine change in the basic political institutions of the state. It is certainly hard to deny that 1649 is a defining change point in the politics of England (and later the UK); that is, that we can speak of pre-1649 England and post-1649 England and in doing so identify a meaningful distinction.

If we are to accept that England in 1649 was experiencing a revolutionary situation parallel to that in France in 1792 and Russia in 1917 we would expect to see a similar idea of influence emerge, and perhaps to manifest itself in concerns about women, about tyranny and about nationalism. Not only were such ideas strongly present in England they similarly coalesced around a single public woman, once again the wife of the reigning monarch. In this case the woman in question was Henrietta Maria, a daughter of Henri IV. Ironically she was criticised for her French heritage by politicians anxious to frame themselves as speaking for England in much the same fashion Marie Antoinette was criticised for her Germanic heritage by those who presented themselves as speaking for France. In the case of Henrietta Maria her religious observance - she was a Catholic and did not, unlike Alexandra Fedorovna, convert to her husband's religion as part of the marriage, let alone practice any new faith devoutly - melded with her foreign extraction neatly in an English political environment where devotion to Protestantism and English-ness were inextricably combined. She was also seen as encouraging disregard for the law and circumvention of legitimate institutions, to the point of actively encouraging rebellion in Ireland. ${ }^{273}$ This perception eventually grew so strong that the Long Parliament passed a law requiring that she be excluded from almost all functions of

273 White, Michelle Anne, Henrietta Maria and the English Civil Wars, Ashgate, Burlington, 2006, p53. 
state. ${ }^{274}$ Parallel to both of her successors she was criticised for inducing and profiting from uxoriousness in her husband and for extravagance in her personal affairs including excessive expenditure on clothes, jewelry and patronage of the arts. ${ }^{275}$

Overall the parallels are striking. It is true, Henrietta Maria's political life diverges significantly from that of Marie Antoinette and Alexandra Fedorovna. Some of the divergences are not significant to our analysis, such as her surviving the events that led up to the death of her husband thanks to a timely flight to France. Some are, such as the relatively greater importance issues of religion played in constructing the narrative of the influential Queen that coalesced around her in contrast to those of her successors in this role. ${ }^{276}$ It is also true that the brief portrait of the role the Queen played in the British Revolution, or indeed of the British Revolution itself, cannot be considered sufficiently substantial to be considered alongside the more fully-fleshed case studies of France and Russia that have been presented. But the study and the similarities it reveal are more than an afterthought, they at least provide prima facie evidence that there is more at work here than the inevitable similarities that will arise between two randomly chosen events if sufficient detail is explored. The fact that the commonalities not only appear at a third point but appear where a review of the phenomenon of modernity-driven revolutions would lead us to expect them to appear adds weight to the contention that anxiety concerning influence, and the presentation of influence to the popular audience necessary to legitimise and sustain revolutionary activity, is the driving force behind these revolutions and the changes they have wrought.

274 The Declaration required that the Queen be barred from influence in 'Matters of Religion, or concerning the Government of any of Your Majesty's Dominions, or for the placing or displacing of any great Officers'. Journals of the House of Commons, vol II, p443.

275 Hunt, The Family Romance of the French Revolution, pp102-3.

276 The fact that religion was so tightly welded to the foreign image of Henrietta Maria but not to Marie Antoinette in the next century or Alexandra Fedorovna still later may be seen as a product of the pre-Enlightenment vintage of Henrietta Maria's political struggles; both the French and Russian Revolutions occurred in post-Enlightenment polities where religion no longer had such a strong hold on the politically insurgent classes, and where national identity could be largely extracted from confessional allegiances. 


\section{Influence and Revolutions:}

At this point the reader will hopefully be satisfied that they appreciate what the author means when he speaks of influence and why he argues that the concept needed to be filtered through the tripartite lenses of gender, tyranny and nationalism could achieve the 'spontaneous combustion', to use the memorable phrase of John Morrill, that constitutes a revolutionary event. ${ }^{277}$ But the question might well be asked - why is it an important thing to know? The idea that the revolutionaries of France, Russia and England were motivated by a perception that government was being transacted inappropriately is not only something that has already been proven, it approaches inanity. The risk of over-explaining what can be explained simply, even if the explanation is factually correct, is something that every scholar must be alert to and it is the author's contention that, while this may initially appear to be the case, this piece has avoided the dilemma which creates this problem.

It has been promised earlier that an understanding of the reasons for the parallels between the political stories of Marie Antoinette and Alexandra Fedorovna would give us greater insight into the changes that the Franco-Russian revolutions imposed on the societies than the events that constituted them played out within. This promise may have been imprecise, for as important as the changes and what motivated them is the changes that did not occur. Although the story of the revolutions is one of discontinuity - indeed, it is radical and lasting discontinuity that makes a revolution - any review of the revolutionary events will quickly reveal that the massive reshaping of societies that one might expect if given only the bare facts of what a revolution means and the knowledge that one has occurred might expect to see. ${ }^{278}$ In both the French and Russian cases it is

277 Morril, p259.

278 It needs to be added as a caveat that this identification of continuity must be considered, in the Russian case, to be concerned chiefly with the February revolution which resulted in the setting up of the Provisional Government, not the October Revolution that replaced it with the Bolsheviks. Obviously attempting to draw a firm line between the two events is problematic but for the purposes of this piece it can be sustained, since the ideologies and narratives sketched by the two groups were so strongly distinct even if the events that those ideologies created were 
easy to identify a chain of antecedents to the actual upheaval that go back for decades. More revealingly it is also easy, when accounting for the final tally of revolutionary change, to enumerate what has remained the same rather than what has been altered. It is tempting to chalk this continuity up to a Burkean cynicism about the ability of human ideology to affect human life; to see a society, even a geographically limited one, as so huge, diverse, counter-intuitive in its workings and possessing such formidable inertia that it swallows change, particularly sudden change. But an alternative explanation, and one that does see societies as capable of change on a human scale, is one that sees the revolutions as having limited effects because their goals were limited, that they were limited projects to begin with.

This concept of influence as the chief animating factor behind the French and Russian revolutions is absolutely complementary to the idea of a limited revolution - an event which embraces the radical discontinuity on a societal level that allows the word 'revolution' to be used but at the same time preserves, even affirms, many of the existing modalities and practices of that society. This is because influence is an extremely limited concept. It encourages the focus of popular anger and violence on individuals or extremely narrow groups bound by institutional ties - on courtiers and bankers rather than the aristocracy or the noble class. It phrases the problem as one revolving around the character of individuals or small groups, such as a family or a circle of friends. If this definition of influence is accepted then it might be asked how anything revolutionary occurred in either France or Russia. But the suggestion of this thesis is too nuanced to justify such a question. The intent is not to argue that the concept of the influence was the only motivating factor in either case. Genuine alienation of large groups harmed by the existing economic and political order was the necessary precondition for the major changes that occurred in both states and was definitely present. A revolution driven solely by a concern for influence would have had more of the character of a palace coup and might have simply resulted in the replacement of the 
monarchies with alternative dynasties. ${ }^{279}$ The French and Russian revolutions deserve the name but this does not mean that their revolutionary nature was uncompromised.

Just as influence was necessary to allow this alienation to be expressed and harnessed on an immediate level, influence coloured the manifestation of this alienation, directing and in some ways muting its expression and its consequences. It allowed those alienated by profound structures to tell themselves that their need to act on that alienation was directed not at profound structures but at surface features of the political system, to tell themselves they were loyal and regenerative rather than subversive and innovative. It captured an ambiguity that lay at the heart of the modernist project itself - its insistence, even as it eradicated the most basic pillars of European intellectual life, that it was simply correcting deviations and restoring the originally intended course.

\section{Concluding Thoughts:}

The contrast between the 'shallow' concept of influence, which almost defies analysis, and the 'deep' consequences of its deployment, in the mobilisation of not one but two revolutions whose downstream effects on world history are unquestioned, is illustrative. This is not to deny the genuine alienation that was felt by the actors but simply to say that their understanding of their alienation was sufficiently incomplete that they had to rely on over-simplifications and narratives more comforting than insightful to allow themselves to mobilise on and communicate their alienation. In constructing these narratives they drew extensively on concepts of gender, nationalism and tyranny that were unified by the concept of influence. This fear of influence was ultimately regressive as it prevented a thoughtful analysis of the situation by revolutionary actors in determining policy.

\footnotetext{
279 This was mooted in both France, with the House of Orleans frequently mentioned as a potential candidate for the throne, and in Russia, where the Czar's cousin the Grand Duke Nicholas, whose dismissal as Commander-in-Chief had evoked such outrage, was often seen as an alternate monarch or regent. In France the House of Orleans actually did take the throne following unrest in 1830 .
} 


\section{APPENDIX:}

\section{BIBLIOGRAPHY}

Alpern Engel, Barbara. Between the Fields \& the City: Women, Work \& Family in Russia, 18611914. Cambridge University Press, New York, 1994.

Alpern Engel, Barbara. Women in Russia: 1700-2000. Cambridge University Press, Cambridge, 2004.

Anderson, Benedict. Imagined Communities. Verson, London, 1991.

Baker, Keith Michael. Inventing the French Revolution. Cambridge University Press, Cambridge, 1990.

Beer, Daniel. 'Microbes of the Mind: Moral Contagion in Late Imperial Russia' in The Journal of Modern History, Vol 79, September 2007.

Belloc, Hilaire. Marie Antoinette. Methuen, London, 1917.

Blackman, Robert H. 'Representation without Revolution: Political Representation as defined in the general Cahiers de Doleances of 1789'. French History, Vol 15, No 2, 2001. 
Bluche, Francois. Louis XIV. Trans Mark Greengrass. Basil Blackwell, Oxford, 1990.

Blum, Carol. Rousseau and the Republic of Virtue: The Language of Politics in the French Revolution. Cornell University Press, Ithaca, 1986.

Buchez, Phillipe-Joseph-Benjamin. Histoire parlementaire de la Revolution Francaise, ou Journal des Assembles Nationals depuis 1789 jusqu'en 1815. Paulin, Paris, 1838.

Burbank, Jane. 'Lenin and the Law in Revolutionary Russia' in Slavic Review, Vol 54, No 1, Spring 1995.

Burke, Edmund. Reflections on the Revolution in France. J Doddsley, Pall Mall, 1790.

Burrows, Simon and Barker, Hannah (eds). Press, Politics and the Public Sphere in Europe and North America, 1760-1820. Cambridge University Press, Cambridge, 2002.

Butler, Judith. Gender Trouble. Routledge, New York, 1990.

Campbell, Peter (ed). The Origins of the French Revolution. Palgrave MacMillan, Basingstoke, 2006.

Carr, William. A History of Germany 1815-1945. Edward Arnold, London, 1969.

Chartier, Roger. Cultural Origins of the French Revolution. Trans Lydia Cochrane. Duke 
University Press, Durham, 1991.

Chrastil, Rachel. 'The French Red Cross, War Readiness, and Civil Society' in French Historical Studies. Vol 31, No 3, Summer 2008.

Christian, David. Imperial and Soviet Russia: Power, Privilege and the Challenge of Modernity. Macmillan, Hong Kong, 1997. p90.

Cirakman, Ash. 'From Tyranny to Despotism: The Englightenment's Unenlightened Image of the Turks' in International Journal of Middle Eastern Studies. Vol 33, No 1, Feb 2001.

Colwill, Elizabeth. 'Just another "Citoyenne?" Marie-Antoinette on Trial, 1790-1793' in History Workshop, No 28, Autumn 1989.

Duff, JD (ed). Russian Realities \& Problems. Cambridge University Press, London, 1917.

Dunn, Susan. The Many Deaths of Louis XVI. Princeton University Press, Princeton, 1994.

Edmondson, Linda Harriet. Feminism in Russia. Stanford University Press, Stanford, 1984.

Figes, Orlando. People's Tragedy. Johnathan Cape, London, 1996.

Figes, Orlando and Kolonitskii, Boris. Interpreting the Russian Revolution: The Language and Symbols of 1917. Yale University Press, New London, 1999. 
Fontana, Biancamaria (ed). Political Writings. Cambridge University Press, Cambridge, 1988.

Fraser, Antonia. Marie Antoinette. Weidenfeld \& Nicholson, London, 2001.

Freeze, Gregory. 'Religion and the Political Crisis in late Imperial Russia' in The Journal of Modern History, Vol 68, No 2.

Freeze, Gregory. 'Subversive Piety: Religion and Political Crisis in Late Imperial Russia'. The Journal of Modern History. Vol 68, No 2, June 1996.

Fuhrmann, Joseph T. Rasputin. Prager, New York, 1990.

Fuller, William C. The Foe Within: Fantasies of Treason and the end of Imperial Russia. Cornell University Press, Ithaca, 2006.

Gellner, Ernest. Nations and Nationalism. Ithaca, New York, 1983.

Gellner, Ernest. Nationalism. New York University Press, New York, 1997.

Goodman, Dena (ed). Marie-Antoinette: Writings on the Body of a Queen. Routledge, New York, 2003.

Gruder, Vivianne. 'The Question of Marie Antoinette: The queen and Popular Opinion Before the Revolution' in French History, Vol 16, No 3, 2002. 
Hunt, Lynn . Eroticism and the Body Politic. Zone Books, New York, 1993.

Hunt, Lynn . The Family Romance of the French Revolution. University of California Press, Berkeley, 1992.

Hunt, Lynn . Politics, Culture \& Class in the French Revolution. University of California Press, Berkeley, 2004.

Hynes, A.L (trans). The Letters of the Tsar to the Tsaritsa. Hoover Institution Press, Stanford.

Johnson, Eric F. 'Revolutionary Politics in Avignon' in French Historical Studies, Vol 30, No 1, Winter 2007.

Kaiser, Thomas. "From the Austrian Committee to the Foreign Plot: Marie-Antoinette, Austrophobia, and the Terror' in French Historical Studies. Vol 26, No 4, Autumn 2003.

Kaiser, Thomas. "Who's Afraid of Marie Antoinette?” in French History, Vol 14, No 3, 2000.

Kates, Gary (ed). The French Revolution: Recent Debates \& New Controversies. Routledge, New York, 1998.

Kelly, Catriona. Utopias. Penguin, New York, 1999.

Kolonitskii, Boris. "'Democracy" in the Russian Political Consciousness of the February 
Revolution' in Slavic Review, Vol 57, No 1, Spring 1998.

Kon, Igor. 'Sexuality and Culture' in Sex and Russian Society. Eds Igor Kon nd James Riordan. Indiana University Press, Bloomington, 1993.

de Keralio, Louise-Felicite Guinement. Les Crimes des Reines de France. Bureau des revolutions de Paris, Paris, 1791.

Kerensky, Alexander. 'Why the Russian Monarchy fell' in The Slavonic and East European Review. Vol 8, No 24, Mar 1930.

LaQueur, Thomas. Making Sex. Harvard University Press, Cambridge, 1990.

Lijphardt, Arend. 'Comparative Politics and the Comparative Method' in The American Political Science Review, Vol 65, No 3, September 1971.

Loukianov, Mikhail. 'Conservatives and "Renewed Russia", 1907-1914' in Slavic Review, Vol 61, No 4, 2002.

Lowe, Heinz-Deitrich. 'Political Symbols and Rituals of the Russian Right, 1900-1914' in The Slavonic and Eastern European Review, Vol 76, No 3, July 1998.

Machiavelli, Nicolo. The Historical, Political and Diplomatic Writings of Nicolo Machiavelli, Vol

2. Trans Christian Detmold. RJ Osgood \& Company, Boston, 1882.

Mautouchet, P. Le Gouvernment Revolutionnaire. Paris, 1912. 
Massie, Robert K. Nicholas and Alexandra. Ballantine Books, New York, 1967.

Miller, Alexei I. The Romanov Empire and Nationalism: Essays in the Methodology of Historical Research. Trans Serguei Dobrynin. Central European University Press, Budapest, 2008.

Moore, Barrington Jr. Social Origins of Dictatorship \& Democracy. Penguin, London, 1991.

Morril, John. The Nature of the English Revolution. Longman Group, Harlow, 1993.

Norberg, Kathryn. 'Incorporating Women/Gender into French History Courses, 1429-1789: Did Women of the Old Regime Have a Political History?' in French Historical Studies, Vol 27, No 2, Spring 2004

Paperno, Irinia. 'The Liberation of the Serfs as a Cultural Symbol' in Russian Review, Vol 50, No 4, Oct 1991.

Pateman, Carol. Sexual Contract. Stanford University Press, Stanford, 1988.

Pares, Bernard. 'On The Appointment of Sturmer as Foreign Minister' in The Slavonic and East European Review, Vol 14, No 41, Jan 1936.

Pares, Bernard. 'Sir George Buchanan in Russia' in Slavonic Review. Vol 3, No 25, March 1925.

Peterson, Dale E. 'Civilizing the Race: Chaadaaev and the paradox of Eurocentric Nationalism' in Russian Review, October 1997. 
Pipes, Richard. A Concise History of the Russian Revolution. Random House, New York, 1995.

Rapport, Michael. 'Robespierre and the Rights of Man' in French History, Vol 10, No 3, 1996.

Read, Christopher. From Tsar to Soviets: The Russian people and their Revolution, 1917-1921.

UCL Press, London, 1996.

Roberts, JM and Cobb, RC (eds). French Revolution Documents, Vol 1. Basil Blackwell, Oxford, 1966.

Rousseau, Jean. The Social Contract and the Discourses. Trans GDH Cole. Random House, London, 1993.

Sade, Marquis de. La philosophie dans le boudoir. London, 1795.

Sagan, Eli. Citizens \& Cannivals: The French Revolution, the struggle for modernity and the origins of ideological terror. Rowman \& Littlefield, Lanham, 2001.

Shlapentokh, Dmitry. The French Revolution in Russian Intellectual Life, 1865-1905. Transaction Publishers, New Brunswick, 2009.

Shragin, Boris and Todd, Albert. Landmarks: A Collection of Essays on the Russian Intelligentsia. Trans Marian Schwartz. Karz Howard, New York, 1977. 
Simonton, Deborah. European Women's Work: 1700 to the Present. Routledge, London, 1998.

Skocpol, Theda. States \& Social Revolitions. Cambridge University Press, Ann Arbor, 1979.

Smele, Johnathan D. Civil War in Siberia: The anti-bolshevik government of Admiral Kolchak, 1918-1920. Cambridge University Press, Cambridge, 1996.

Stanley, Elva Mills. 'Nursing and Citizenship' in The American Journal of Nursing. Vol 1, No 16, October 1915.

Stites, Richard. The Women's Liberation Movement in Russia: Feminism, Nihilism and Bolshevism 1860-1930. Princeton University Press, Princeton, 1978.

Stockdale, Melissa Kirsche. Paul Miliukoff and the quest for a Liberal Russia. Cornell University Press, Ithaca, 1996.

Tackett, Timothy. 'Collective Panics in the early French Revolution 1789-91: A Comparative Perspective' in French History, Vol 17, No 2, 2003.

Taylor, Craig. "The Salic Law and the Valois succession to the French Crown" in French History, Vol 15, Dec 2001.

Thomas, Chantal. The Wicked Queen: The Origins of the Myth of Marie-Antoinette. Trans Julie Rose. Zone Books, New York, 1999.

de Toqueville, Alexis. The Old Regime and the French Revolution. Trans John Bonner. Harper \& 
Bros, Franklin Square, 1856.

Tolz, Vera. Inventing the Nation: Russia. Oxford University Press, New York, 2001.

Trotsky, Leon. The History of the Russian Revolution, Vol 1: The Overthrow of Czarism. Trans Max Eastman. Victor Gollancz, London, 1934.

Verner, Andrew M. The Crisis of Russian Autocracy. Princeton University Press, Princeton, 1990.

Vitarbo, Gregory. 'Nationality Policy and the Russian Officer Corps' in Slavic Review, Vol 66, No 4, Winter 2007.

Weber, Eugen. Peasants into Frenchmen. Stanford University Press, Stanford, 1976.

Weber, Max. The Russian Revolutions. Trans Gordon C Wells and Peter Baehr. Polity Press, Cambridge, 1995.

Weeks, Theodore R. Nation and State in late Imperial Russia: Nationalism and Russification on the Western Frontier, 1863-1914. Northern Illinois University Press, Dekalb, 2008.

White, Michelle Anne. Henriette Maria and the English Civil Wars. Ashgate, Burlington, 2006.

Williams, David Lay. 'Modern theorist of tyranny? Lessons from Rousseau's system of Checks and Balances' in Polity, Vol 37, No 4, Oct 2005.

Wood, Alan. The Romanov Empire 1613-1917. Hodder, London, 2007. 
Youssoupoff (sic) Felix. Rasputin. Johnathan Cape, London, 1927.

Zimmerling, Ruth. Influence and Power: Variations on a Messy Theme. Springer Netherlands, 2005.

Author Unknown:

Bord... R... Suivi d'un entretien secret entre la Reine et le Cardinal de Rohan, apres son entree aux Etats-generaux. Paris, 1789.

L'Autrichienne en Gouguettes, Paris, 1789.

Essais Historiques sur la Vie de Marie-Antoinette, reine de France, pour server a l'histoire de cette prinecess, Paris, 1789.

La Godmiche Royale, Paris, 1789. 